\title{
Glacial Striae, roches moutonnées and ice movements in the Faeroe Islands
}

By Gunni Jørgensen and Jóannes Rasmussen
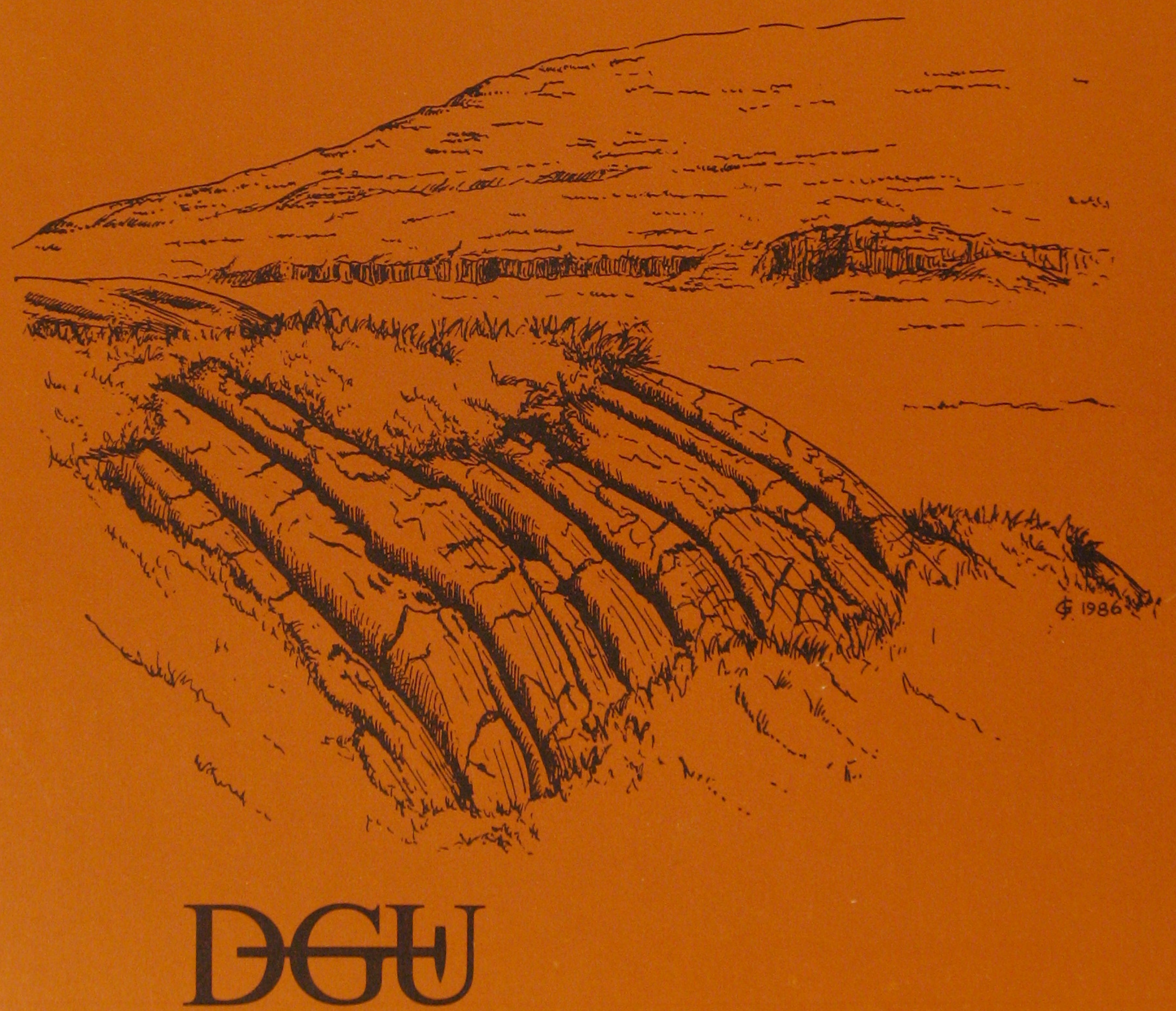

Geological Survey of Denmark Ministry of the Environment 1986 


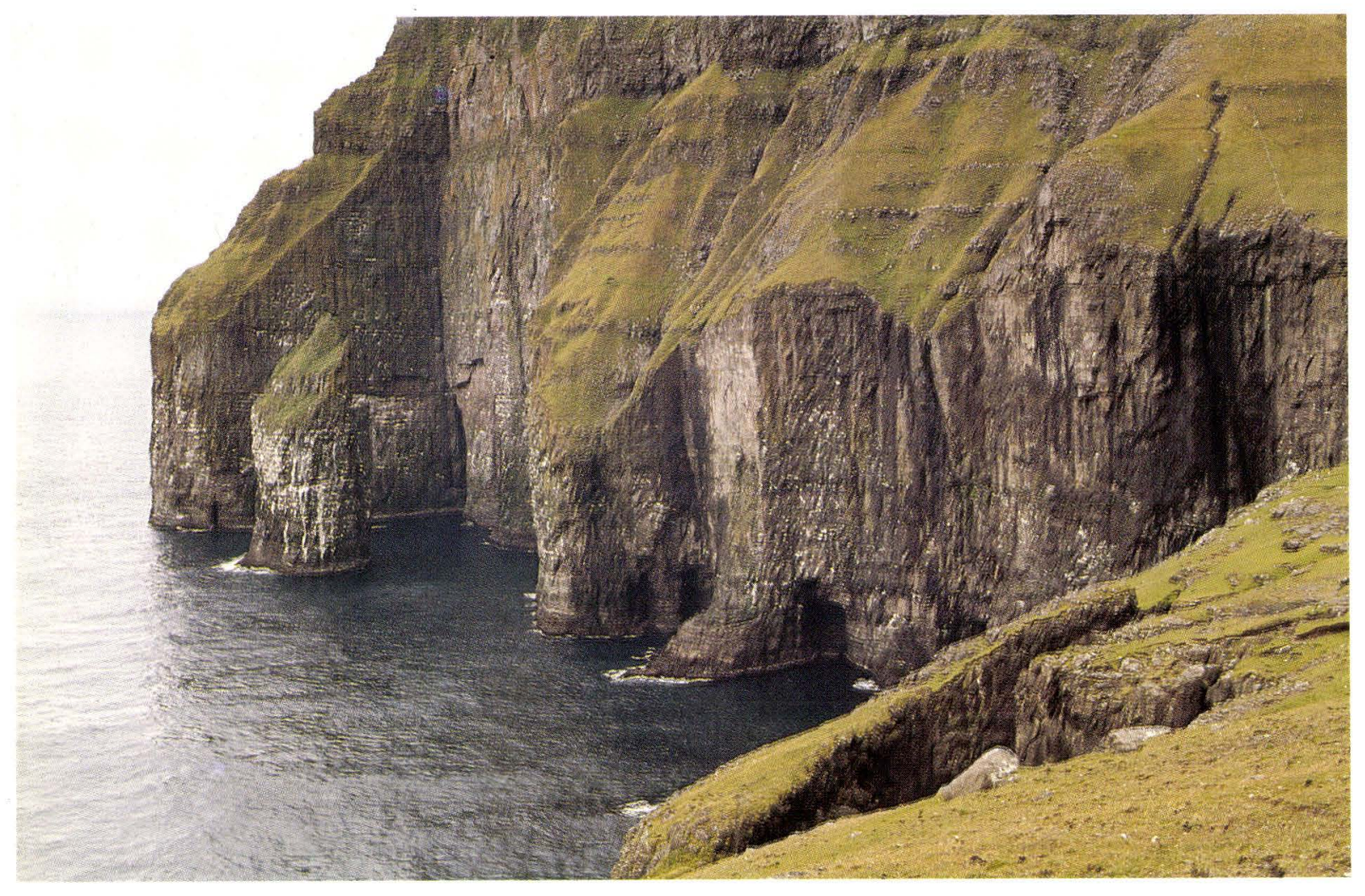

Erosional remnants of a supposed former cirque in the high perpendicular seacliff west of Sandvik, Suouroy. 


\section{Glacial Striae, roches moutonnées and ice movements in the Faeroe Islands}

By Gunni Jørgensen and Jóannes Rasmussen December 1986

DGU series $\mathrm{C}$ no. 7

ISBN 87-88640-36-1

ISSN 0900-6362 


\section{Keywords :}

Glacial Striae, roches moutonnées, ice movements, Faeroe Islands

\section{Vignette:}

Heavily glaciated landscape at the village of Eiơi, Eysturoy.

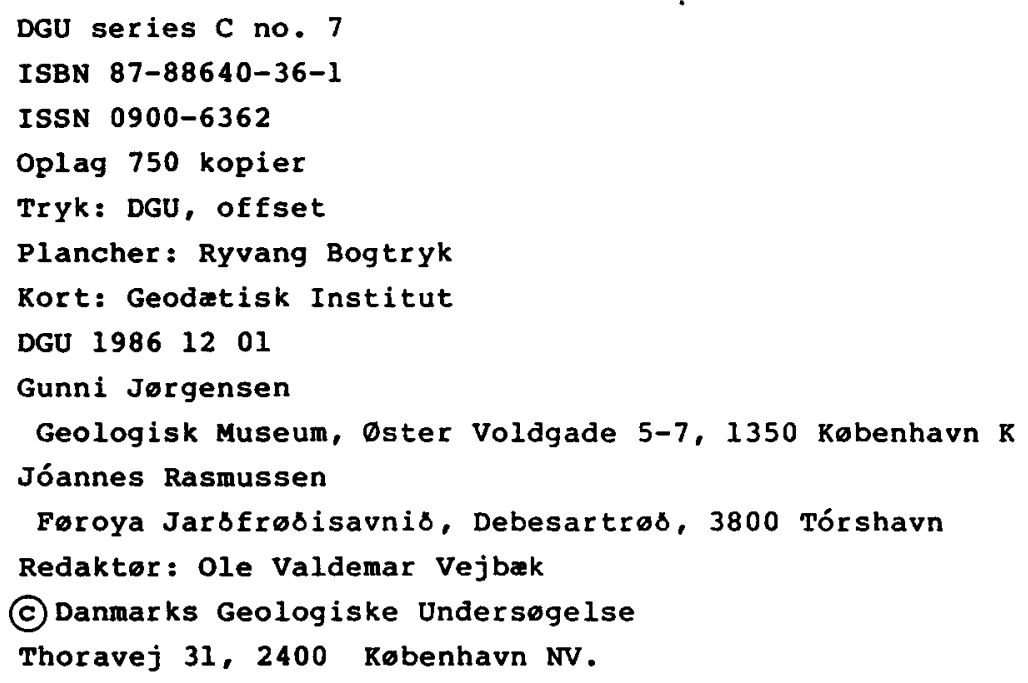




\section{CONTENTS}

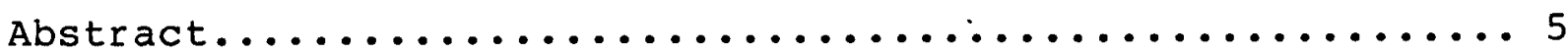

Introduction. ...........................

Outline of the pre-Quaternary geology.................

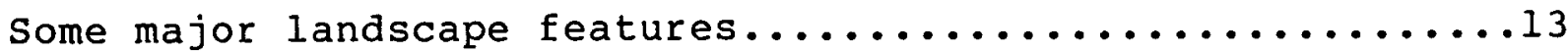

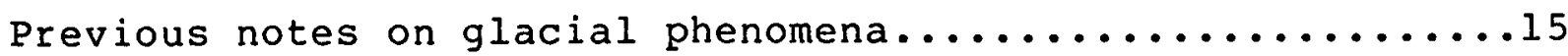

Glacial striae, roches moutonnées and methods

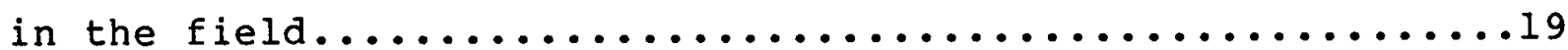

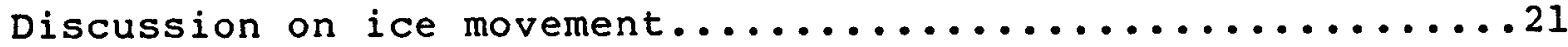

Conclusions................................43

Acknowledgements............................ 45

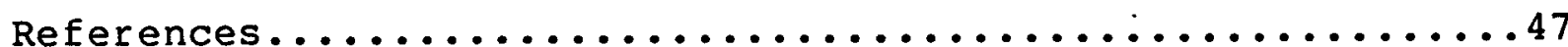

Appendix: Description of localities.................49

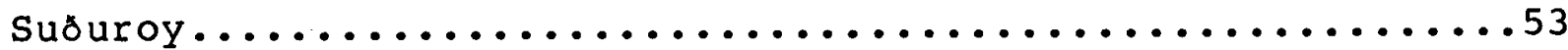

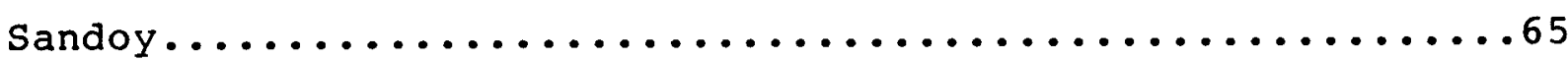

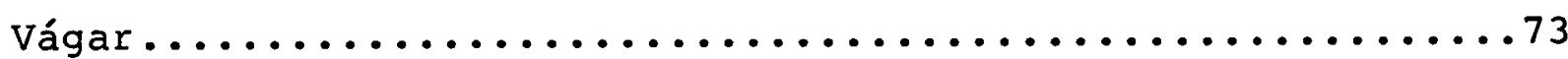

streymoy $\ldots \ldots \ldots \ldots \ldots \ldots \ldots \ldots \ldots \ldots \ldots \ldots \ldots \ldots \ldots \ldots \ldots$

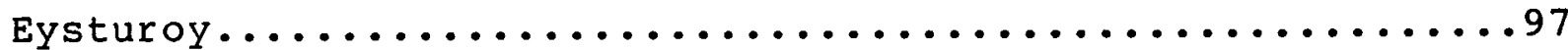

Nordoyar (the northern most group of islands)..........109 
The paper deals with glacial striae, roches mountonnées and ice movement in the Faeroe Islands. On an enclosed map, striae and roches moutonnées, partly observed during other field work, are presented together with description of localities. Ice movement is discussed with reference to older works, and it is concluded that the ice reached up to altitudes of more than $700 \mathrm{~m}$ and extended far beyond the present coast line. Suouroy and Sandoy each had a local ice cover, at least during the last glaciation, and in the northern islands the ice radiated out from a principal iceshed running from vágar to viooy. 
The present paper "Glacial striae, roches moutonnées and ice movement in the Faeroe Islands" is based on observations in the field during the last fifteen years supplemented by some older observations made during the pre-Quaternary mapping of the islands.

The paper should not be considered as a final work on ice movement in the Faeroe Islands but as a statement of our observations on the subject to date accompanied by a map and an appendix with description of localities (see fig. 13).

In addition to the authors, Peter B. Konradi took part in the field work for one season. In some cases we refer to earlier observations made by Andr. Højgaard $(p, 16) \ldots$, and other authors, in order to fill out gaps in our own knowledge.

Our detailed original observations are all deposited at Føroya Jarofrøoisavn (the geological section of the Museum of Natural History in Tórshavn).

On the enclosed map striae and roches moutonnées are shown as small red arrows with location numbers referring to the text. The larger arrows show the main course of the ice movements. Where the principal iceshed has been directly observed by means of roches moutonnées, it is shown on the map as a heavy red line with arrows in two opposing directions.

The enclosed map was printed at the Geodætisk Institut, Copenhagen. All place names mentioned in the text are found on the map, and their spelling is in accordance with official Faroese usage. 
The Faeroe Islands are of volcanic origin. They were erupted as part of an extensive, now mainly submerged, lava sequence in connection with the opening of the NE Atlantic ocean in Early Tertiary time. The visible lava pile has a cumulative thickness of more than $3000 \mathrm{~m}$ of tholeitic basalt comprising a lower, a middle and an upper series (Rasmussen and Noe-Nygaard 1969, 1970). The oldest flows occur in two updomed areas, one in the southern and one in the western part of the islands (Schrøder 1971). A deep well which was drilled in 1981 on southern Sururoy added $2178 \mathrm{~m}$ to the known part of the lower basalt series (Berthelsen et al. 1984).

The lower and middle basalt series on suouroy and Vágar are separated by an approximately $10 \mathrm{~m}$ thick coal-bearing sedimentary sequence, overlain by a tuff-agglomerate zone which represents the initial explosive phase of the middle basalt series. The final phase in the volcanism is marked by the intrusion of dykes, irregular intrusive bodies and sills (Rasmussen \& Noe-Nygaard 1969, 1970).

The Faeroese lava plateau has thus been divided into: 1 . The lower basalt series, 2. The coal-bearing series, 3. The tuffagglomerate zone, 4. The middle basalt series, 5. The upper basalt series, and 6 . Intrusive rocks; these reflect the progress of the volcanism (fig. 1 ).

The lava flows mostly have gentle NNE to ENE dips on the southernmost island, Suóroy, and ESE to SE dips on the northern islands.

The volcanic activity started as large fissure eruptions which had a rhythmic character. The exposed part of the lower basalt series has a total thickness of ca $900 \mathrm{~m}$; the single flows 


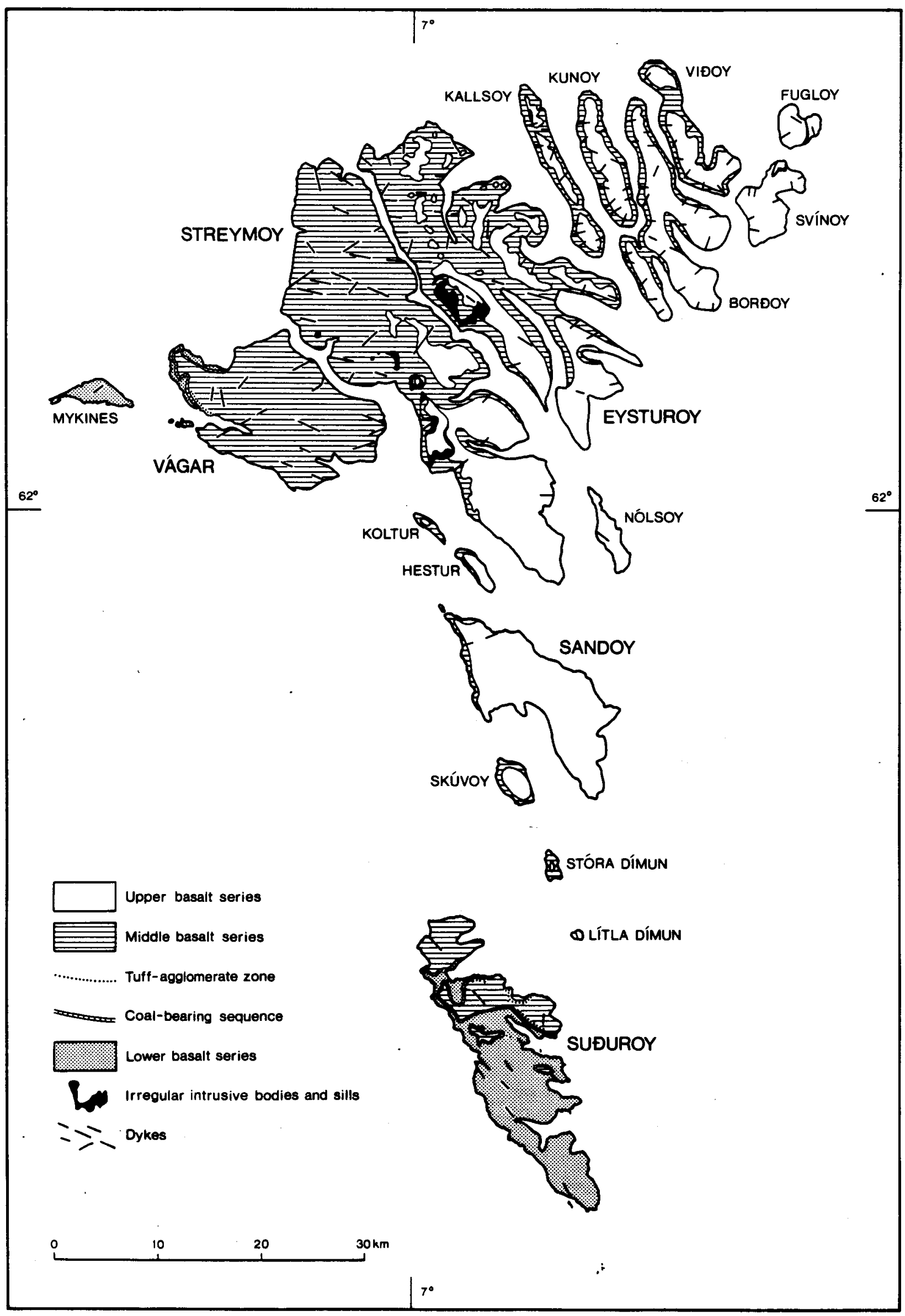

Fig. 1. Geological map of the Faeroe Islands (after Rasmussen and Noe-Nygaard 1969). 
average about $20 \mathrm{~m}$, and have a reddish, slaggy and porous surface. Columnar jointing occurs everywhere, but is most pronounced in the top of the series. Petrographically the flows of the lower basalt series are very monotonous; they consist of fine-grained, hard, dark basalt, generally without phenocrysts. Thin tuffaceous or clay layers occur between the lava flows; these layers become more frequent and increase in thickness upwards and seem to indicate a gradual slowing down in the volcanic activity.

A break in the volcanic activity is marked by subaerial weathering and disintegration. On this uneven, eroded surface about $10 \mathrm{~m}$ of clayey coal-bearing sediments were deposited. The thickness of the coal layers varies from place to place, but averages about $0.75 \mathrm{~m}$ in the western area. The coal is allochthonous; fragments of more or less coalified stems, roots and leaves of Metasequoia occidentalis have sometimes been retrieved from the coal mines (Rasmussen \& Koch 1963). Stratigraphically the coal-bearing sequence connects suôroy with vágar and is shown as a marker horizon (A) on the geological map.

After a rather long period of quiescence, with deposition of the coal-bearing beds, the volcanic activity recommenced with a highly explosive initial phase producing pyroclastic materials: volcanic bombs, lapilli and ash. Lava production was minimal. The pyroclastic material accumulated with variable thickness along eruption fissures on northern suburoy and western Vágar, and consolidated as agglomerates and tuffs.

When the explosive activity drew to a close, an almost continuous lava production set in and formed the middle basalt series, with a total thickness of about $1400 \mathrm{~m}$. The lavas were probably produced from somewhat elongated vents or small fissures along the NW-SE trending fjords. Individual lava flows are thin and usually separated by highly vesicular zones. The lava flows become thicker, and tuff beds more common, upwards in the series. The rocks of the middle basalt series show great variation. About $900 \mathrm{~m}$ above the marker horizon (A) a conspicuous lava escarpment, a unit of thin lava flows, is seen; it 
can be traced from western Vágar to western Eysturoy and has been used as an auxiliary marker horizon (B).

After a break in the volcanism of unknown duration, marked by intense weathering of the surface and minor unconformities, volcanic activity recommenced and formed the upper basalt series. The volcanic activity, which was continuous during the formation of the middle basalt series, now again had a rhythmic character. The boundary between the middle basalt series and the upper basalt series is another marker bed, the c-horizon, which corresponds with the lower limit of one or more flows of hard, bluish basalts separated by zeolite-filled vesicular zones. The lava flows of the c-horizon overflowed the uneven, weathered and eroded surface of the middle basalt series. The upper basalt series has a total thickness of about $700 \mathrm{~m}$; individual flows average $10 \mathrm{~m}$ in thickness, and are generally intercalated with tuff beds.

Following build up of the total lava pile by effusive volcanic activity, a period of tension led to the formation of fractures and subsequently intrusion of basaltic rocks. Intrusive rocks occur as dykes, irregular intrusive bodies and sills. Dykes were intruded into vertical, or almost vertical fractures (master joints, lamellar zones) penetrating the entire basalt plateau; irregular intrusive bodies were emplaced into the tuff-agglomerate zone and the coal-bearing sequence; sills intrude the border zone between the middle and the upper basalt series. Most of the numerous dykes occur in a belt traversing the northern islands from WSW (Vágar) to ENE. Sills occur on Streymoy, Eysturoy and Fugloy-Svínoy. Irregular intrusive bodies are found on suơuroy, Tindhólmur and Vágar. 
The three basalt series each have their own characteristic main landscape form determined by rock type, rock structure and erosive agencies (Rasmussen 1982).

In the lower basalt series the thick and resistant lava flows are interbedded with less resistant clayey sediments and pyroclastics. The erosion has therefore given rise to a "trap" formed landscape, vegetation-covered gentle slopes alternating with steep basalt cliffs.

In the middle basalt series the thin lava flows are usually welded together, but are poorly resistant to weathering and erosion. The more advanced disintegration of rocks at higher levels and removal of material to lower levels has given rise to characteristic convex-formed slopes in the middle basalt series.

In the upper basalt series, basalt and tuff beds again alternate, so the typical "trap" landscape dominates. However, as the flows in the upper basalt series are generally thinner than in the lower basalt series, the hill slopes have smaller steps in the "trap" topography.

The coal-bearing sequence and the tuff-agglomerate zone occur in the field as a grass-covered, rather steep, slope between the lower basalt series and the middle basalt series.

The Faeroe plateau is divided into a group of elongate islands by a NW-SE trending fjord system. The trend of the fjords corresponds to the fissure system through which the lavas were extruded. It is assumed that the fissures originally followed tectonic lineaments established prior to the volcanism, and subsequently excavated by pre-glacial and glacial erosion to 
form the present NW-SE trending fjords and related valleys.

The highest mountains generally occur in the north. The mountains are arranged in longitudinal, almost NW-SE trending, zigzag lines.

Everywhere the islands exhibit typical glaciated landscape forms, U-shaped valleys and smoothly polished mountain sides. Large and small cirques occur along the valleys or open towards the fjords. While the cirques on the east coasts fall gently towards the sea, those of the west and north coasts often terminate in precipitous, almost vertical, sea cliffs. 
While the pre-Quaternary geology of the Faeroe Islands has been the subject of increasing geological surveying and systematic geological mapping in recent decades, our knowledge of the Quaternary geology, with the exception of a few recent minor publications, is still mainly based on works dating from the last century.

Glacial phenomena in the Faeroe Islands were first drawn attention to and described by Thomas Allan who visited the Faeroes together with Sir George Mackenzie in 1812. He does not directly ascribe the phenomena to glacial action, but describes furrows in the bedrock and polished bedrock exposures near the settlement of Eioi (Allan 1814).

The first to observe and recognize striae and roches moutonnées as glacial phenomena was the British author and publisher Robert Chambers. He stayed in the Faeroe Islands for a few days in 1855 together with Robert Allan, a son of Thomas Allan. In the vicinity of Tórshavn he recognized the rounded character of the rock surface to be the result of glacial abrasion, and in Vestmanna he observed glacial striae. The locality at Eisi described by Allan (see appendix p. 97) was also visited, and he concluded that the striae and scratches were all directed from the north and that the Faeroe Islands had been covered by an arctic ice sheet (Chambers 1855).

However, the principal geological works of the last century referring to the glaciation were those of Helland $(1879,1880)$ and Geikie (1880). Amund Helland and James Geikie travelled in the Faeroes together in 1879. The principal object of their journey was to examine the glacial geology of the islands, but both of them also gave a complete account of the general geology of the Faeroes. They agree in their general conclusions in 
all essential aspect of the glaciation. Helland (1879, 1880) describes some striae and roches moutonnées; his paper is accompanied by a map showing their direction and distribution. He shows that the observed roches moutonnées indicate that the ice radiated outwards from the islands, and that the Faeroes thus had a local glaciation. In agreement with Geikie he estimates that the northern islands must have had ice cover to a height of about $500 \mathrm{~m}$ (Geikie records 1600 feet), while on suouroy he observed roches moutonées surfaces up to an altitude of about $440 \mathrm{~m}$ (Geikie records 1400 feet). Geikie's (1880) paper is also accompanied by a map showing the distribution and direction of glacial striae and roches moutonnées. Like Helland he concludes that the Faeroe Islands had a local glaciation, and shows that a primeval watershed - an undulating line drawn from NE to $S W$ between Svínoy and Vágar - also marks out the centre from where the "mer de glace" flowed. Like Helland he shows that on suouroy the glaciers moved both eastward and westward (Fámjin, Vágseiòi), although at Hvalbiarfjørơr he only observed roches moutonnées indicating ice movement from the east to the west.

Karl Grossmann and Joseph Lomas visited the Faeroes in the summers of 1892 and 1894. In their paper and on their map (Grossmann \& Lomas 1895) they record some striae and roches moutonnées. Like Helland and Geikie they consider the Faeroes to have been locally glaciated, the ice reaching a height of about $500 \mathrm{~m}$ (Mykines), and they refer to the iceshed of the northern group of islands already pointed out by Geikie. However, they do not consider that the valleys and fjords were created by the ice, as suggested by Chambers, but rather that the ice modified pre-glacial valleys.

Hans Rudolphi who visited the Faeroes in 1912 and 1913 refers in his paper "Die Furber" (Rudolphi 1913) to glacial striae and roches moutonnées from streymoy, sandoy, Eysturoy and Vágar, and he gives some heights for the glaciated outline, which on northern Eysturoy reached almost $600 \mathrm{~m}$.

Some years ago, Andreas Højgaard, the principal of the College 
of Education in Tórshavn, submitted a paper to the University of Copenhagen on ice movement in the Faeroes. The paper is, however, lost, but a map compilation of striae and roches moutonnées from Helland (1880), Geikie (1880), Grossmann \& Lomas (1895) and some other observations is kept in the geological department (Museum of Natural History) in Tórshavn.

The problem of the ice extension on the shelf south-east of the Faeroe Islands has been dealt with in a recent paper by waagstein \& Rasmussen (1975).

Three provisionally papers on striae and roches moutonnées on Suouroy, Sandoy and southern streymoy and Eysturoy have been published by Jørgensen \& Rasmussen (1977, 1978, 1981). 
Glacial striae and roches moutonnées are seen all over the islands. In some parts of the country striae and roches moutonnées are very abundant with well developed striae, sometimes as deep furrows; in other places they are few, faint and hardly visible. Roches moutonnées can be perfectly well formed but where the rock ground is weak and porous they are often broken up and weathered so the stoss and lee sides are hardly recognizable. Where certain tracts of country are completely scree and soil covered, observations are quite impossible. The distribution of striae and roches moutonnées shown on the map is therefore very uneven from place to place. The striae and roches moutonnées noted in the paper are mostly well developed, where this is not so it is pointed out in the text.

Distinct and well developed striae and roches moutonnées are mostly found in the lower basalt series, on sill surfaces and in the middle and the upper basalt series where compact and hard lava flows are encountered. In the porous and thin lava flows of the middle basalt series they are usually badly preserved, but if the soil has recently been removed they are often clearly visible.

Owing to the magnetic variation and to the variable mutual direction of the same set of striae at the same locality, the trends of roches moutonnées and striae were laid down in the field and fixed on the map with reference to characteristic features in the terrain. The magnetic variation alters considerably from place to place in the Faeroe Islands. Geomagnetic measurements at Akraberg and at Porkeri on Suouroy, a distance of about $10 \mathrm{~km}$ apart, thus give the values $-15^{\circ} 18.1$ and $-8^{\circ} 24.6$; at the airport (flogvøllur) and Hotel Vágar, a distance of about only $600 \mathrm{~m}$, values of $-10^{\circ} 40.3$ and $-14^{\circ} 29.3$ are found (Hansen 1982). 
Considering these natural variations we have preferred to express the trends with reference to cardinal points corrected to the nearest cardinal, half cardinal or three letter cardinal point. 
The observed glacial striae and roches moutonnées drawn on the enclosed map are mentioned separately for each island in the attached appendix. Each island is divided for descriptive purposes into smaller areas, where localities are described and where striae and roches moutonnées are listed (see appendix). site numbers mentioned in the appendix refer to site numbers on the enclosed map.

SUDUROY. As stated by Helland (1880) and Geikie (1880) the striae and roches moutonnées on suóruroy indicate ice movements to the east as well as to the west, and these authors point out that the glaciated outline can be traced up to an altitude of ca $440 \mathrm{~m}$.

Our investigation of the striae, roches moutonnées and icesheds on suouroy show that the island had its own ice cap, at least during the last glaciation, and that the principal iceshed was near the present west coast.

Observations based on the opposing directions of roches moutonnées indicate that the principal iceshed followed the long axis of the island as an undulating NW-SE trending line. At Loprans eiði,. Vágseiði, Botnsskarð and west of Sandvík the present watersheds were observed to be situated a little to the west of the iceshed.

At Sandvik the iceshed was close to the west coast, the eastward directed ice draining through the valley to sandvik and the westward directed ice extending out beyond the steep coastline, where remnants of former cirques occur in the $100 \mathrm{~m}$ high, almost perpendicular seacliff.

In Hvalba the iceshed was in the innermost part of the fjord, 
the west moving ice diverging in a NW direction through Nor $8-$ bergseioi and in a $S W$ direction through Hvalbiareioi. East of the iceshed the glacier from the valley south of Hvalba moved in a north-west direction to Hvalbiarfjorour where it turned to the east. Geikie (1880) noted only west moving ice at Hvalbiarfjørơr.

At Botnsskaro the iceshed lies east of the small lake near the west coast. The glacier east of the iceshed followed the valley to Trongisvágsfjørour. West of the iceshed the cirque, Trongisvágsbotnur, opens in the same sw direction as indicated by striae and roches moutonnées at Botnsskaro (fig. 2).

Between Fámjin and Hov, where Helland (1880) and Geikie (1880) pointed out that the upper limit of the ice cover extended to ca. $440 \mathrm{~m}$, the iceshed probably followed the mountain ridge Laóafelli - Borgarknappur - Hvannafelli; the ice east of the iceshed moved through the strongly glaciated valley above the village Hov, while west of the iceshed it diverged $\mathrm{NW}$ to Fámjin and SW to Botnur.

At Vágseiori the iceshed is probably to be found at the innermost part of Vágsfjørour. It is likely that the ice from Botndalur diverged into an eastward flowing branch and a westward flowing branch between the lake and the innermost part of the fjord.

At Lopra the iceshed is situated in the southern part of Lopransfjørour at Oyrnatangi. From here the ice moved WSW to Lopranseiói and NNE following Lopransfjørour. At the entrance to Vágsfjørour it turned eastward (Helland 1880). 


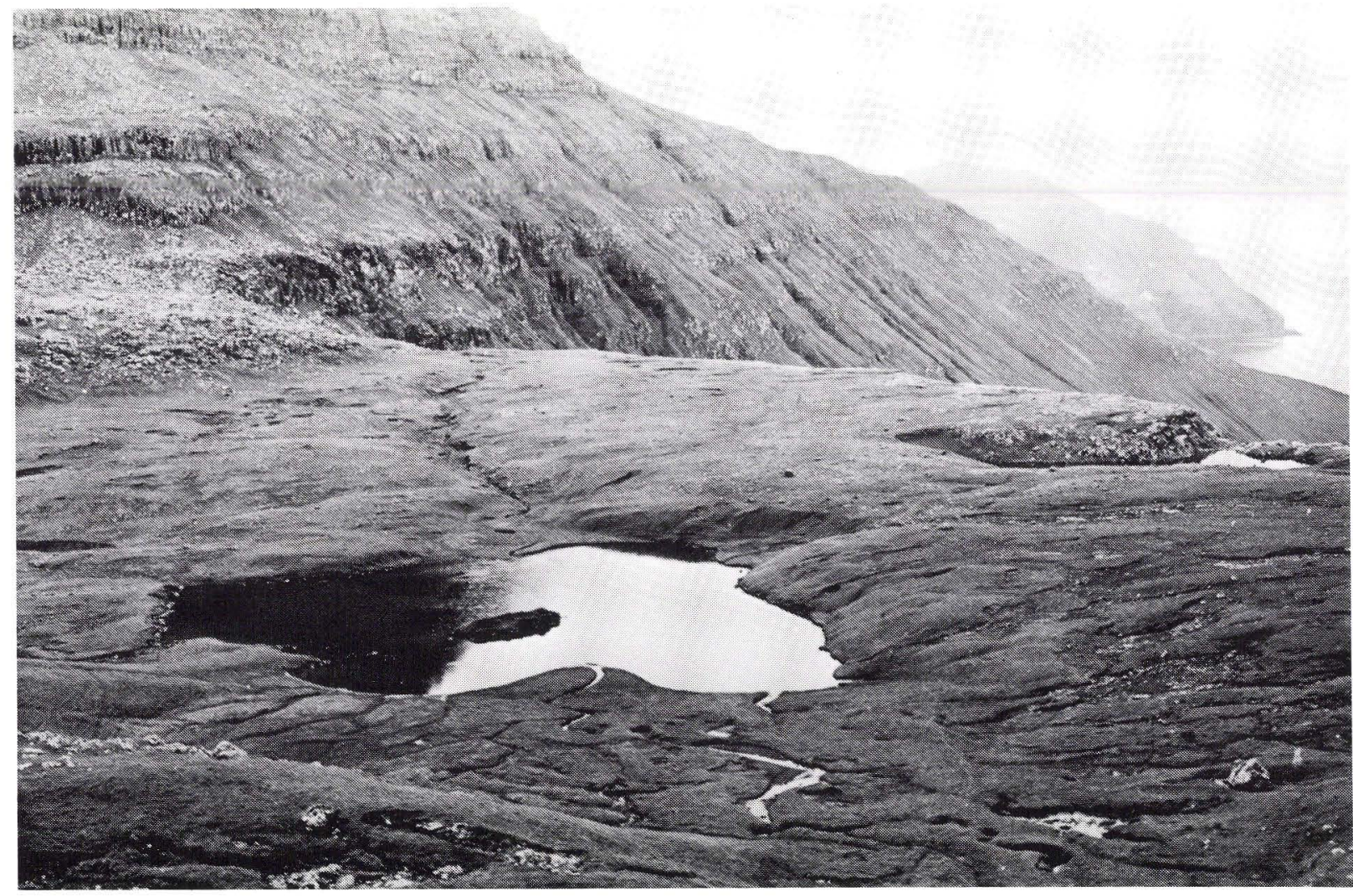

Fig. 2. Glaciated rock showing ice movement towards the SW (site 73). Botnsskarð, Suðuroy. 
SANDOY. The striae and roches moutonnées on Sandoy indicate that the ice cover on Sandoy, like that on suoruroy, radiated outwards from the present land area during the last glaciation. On the east side of sandoy the ice direction varies from NNW (north of Skopun), to NE (Skálavík) and SE (Húsavík and Dalur). On the west side of Sandoy the direction is westerly at søltuvik and at the valley north of Skarvanes.

The iceshed between Húsavik on the east coast and the lakes Stóravatn and Litlavatn to the west is situated immediately east of the present watershed, which continues north along the mountain ridge Pætursfjall - Tindur - Reynsendi.

In the area between Gróthúsvatn and Lækjá the ice direction was nearly due SE. In Sandsdalur, the NNW-SSE trending valley between Skopun and Sandur, the ice flowed northward and southward from the iceshed which was situated at the southern end of Heimara Hálsavatn. At Sandur the south flowing ice from Sandsdalur suddenly changed direction to the $S W$ when it reached the already existing lower and shorter western flank of Sandsvágur (fig. 3).

THE NORTHERN ISLANDS. Geikie (1880) pointed out that if a somewhat undulating line was drawn NE-SW between Svínoy and Vágar, this line would represent the primeval watershed, the chief iceshed and the present main watershed of the islands.

In order to define the chief iceshed more exactly in Saksunardalur, Sundini, the valley between Funningsfjørơr and skálafjørour, Haraldssund and Hvannasund, the line of the iceshed was traced WSW-ENE from Saksunardalur to Hvannasund.

Near the middle of the valley Saksunardalur, between Dalsá running down to Saksun and Stórá running down to Hvalvík, there is a hummocky area with moraine hills reaching heights of $8-9$ $\mathrm{m}$. The area is about $\mathrm{I} \mathrm{km}$ across (fig. 4). The iceshed in the valley is situated near the outlet of Ravnagilsá immediately east of the watershed. Striae and roches moutonnées show that a NW flowing ice stream flowed from here to saksun, while a SE 
flowing ice stream moved from here through the valley and turned south towards Sundini at Hvalvik.

Between Noróskáli and Oyrarbakki in sundini the water depth is $5 \mathrm{~m}$ or less. The lowest water depth was $2 \mathrm{~m}$ at the bridge between Eysturoy and streymoy, but during construction of the bridge the fjord at this locality was deepened to $4 \mathrm{~m}$ (fig. 5).

As mentioned above, the glacier from Saksunardalur turns south towards Sundini at Hvalvík. A clear north flowing ice movement in Sundini, however, can first be ascertained at the village of Noroskáli; here the glacier from a WNW-ESE trending valley above the village flowed WNW at the village and to the NW north of the village. In the valley above oyri the ice direction is westerly, but south of Oyri it becomes more southerly.

The iceshed in Sundini must therefore be situated in the area between Noróskáli and Oyrarbakki.

At the watershed in the valley between skálafjørour and Funningsfjørour the stream Vesturdalsá bifurcates into Vesturdalsá, continuing NW to Funningsfjørơur, and into Fjarơará in the opposite direction to Skálafjørour. The watershed occupies the swampy area between Vesturdalsá and Fjaroará. The iceshed is situated $70-80 \mathrm{~m} \mathrm{a.s.l.} \mathrm{west} \mathrm{of} \mathrm{the} \mathrm{small} \mathrm{lakelet} \mathrm{at} \mathrm{the}$ watershed. Immediately NW of the lakelet, striae and roches moutonnées point to the $\mathrm{SE}$, but about $500 \mathrm{~m}$ farther to the north-west they point NW.

As in saksunardalur the area is hummocky, occupied by numerous moraine hills (fig. 6).

In Haraldssund the iceshed is situated immediately south of Strond. The lowest depth of water is between strond and the village of Haraldssund (fig. 7). In the lower part of strandardalur, the valley above strond, the ice direction turns more and more towards the NE north of the river, and more and more towards the SW south of the river. 


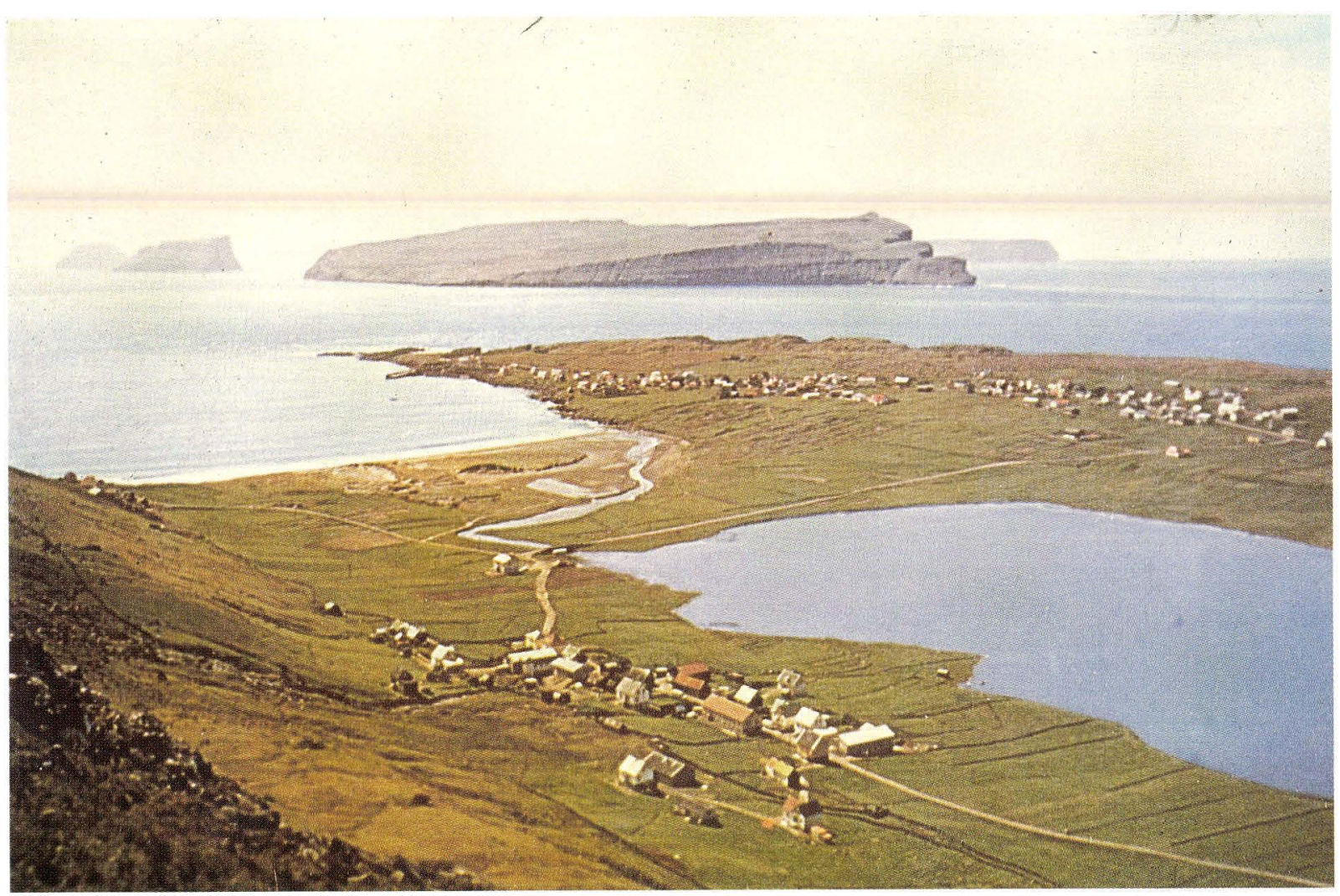

Fig. 3. The lake Sandsvatn with dune landscape in the foreground. The little peninsula west of the bay is strongly glaciated. Striae and roches mountonnées indicate here that the SE flowing ice from sandsdalur suddenly changed direction to the SW (see fig. 16): 


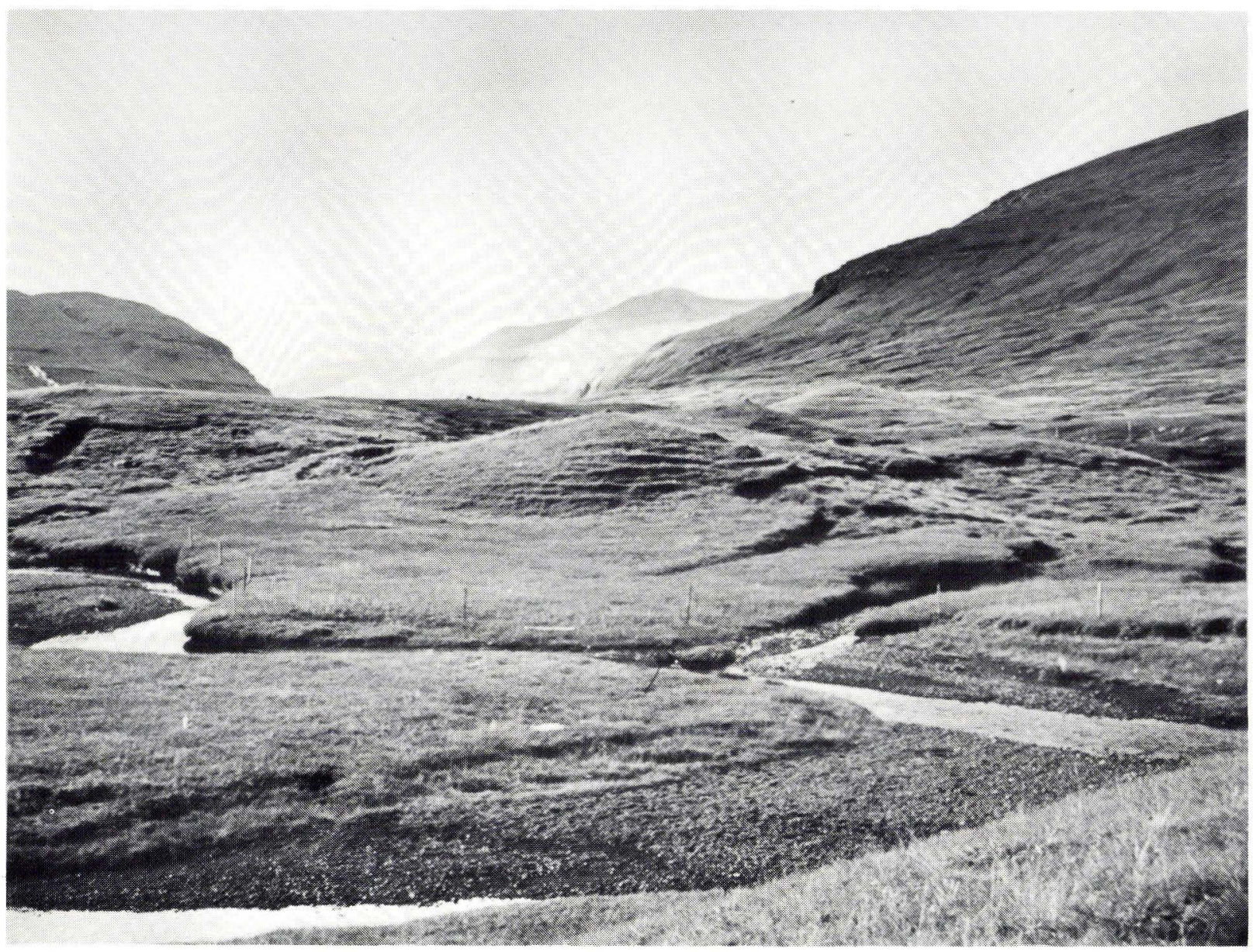

Fig. 4. Moraine hills reaching heights of 8-9 $\mathrm{m}$ near the iceshed between Dalá and Stórá in Saksunardalur, Streymoy. 


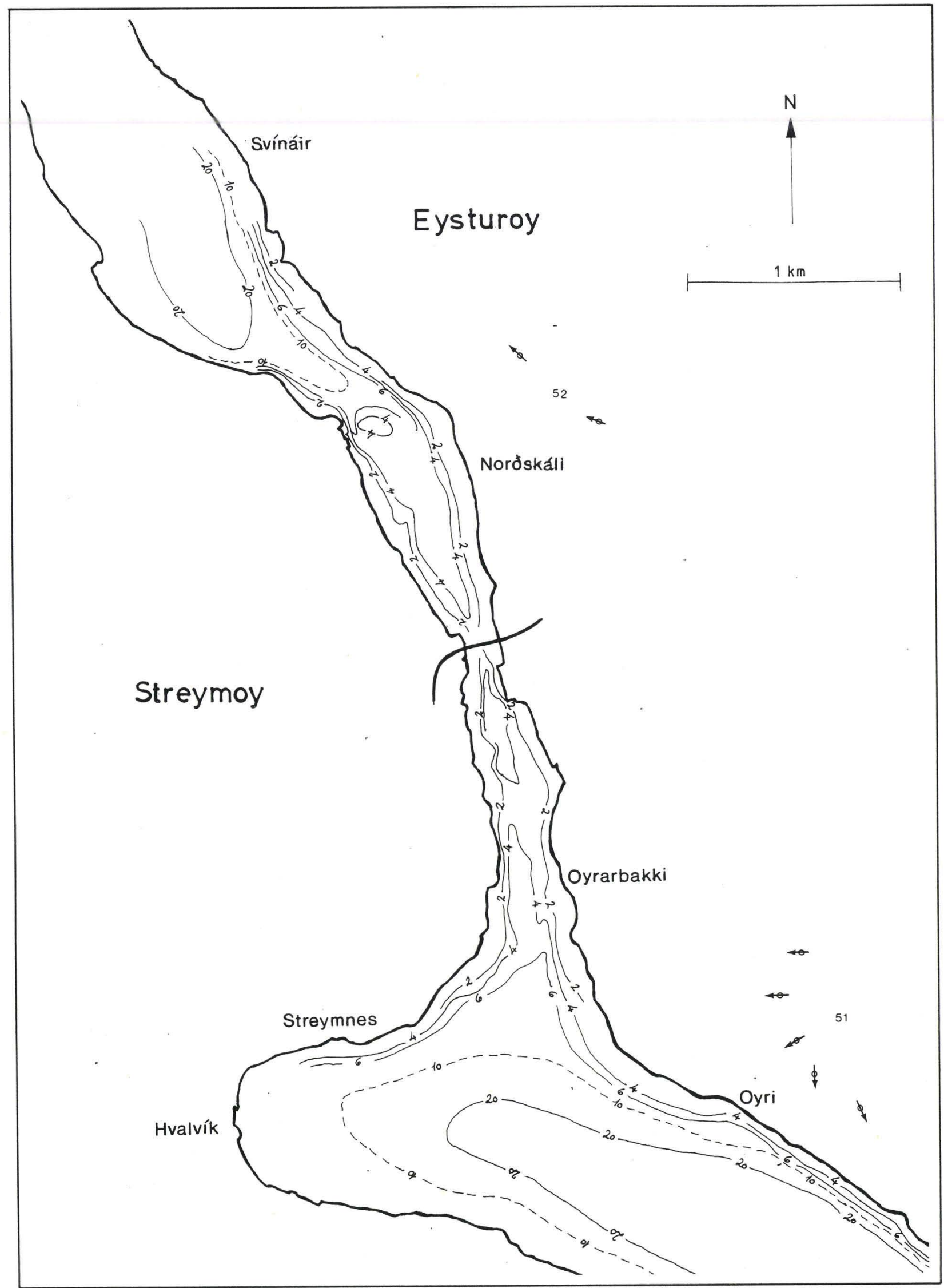

Fig. 5. Map showing bottom topography at the iceshed in sundini between Oyrarbakki and Norðskáli. 
The lowest depth of water in Hvannasund is between the two villages Norodepil and the village of Hvannasund. The lowest depth in the centre of the sound is 3-4 m west of the church in the village of Hvannasund increasing slightly both towards the $\mathrm{N}$ and towards the $\mathrm{S}$ (fig. 8). Northward directed ice movement was noted at Leitio (site 2) and southward directed ice movement on the C-horizon flow above the church in Hvannasund (site $3)$. The iceshed is therefore probably located in the area between the two villages.

In Vestmannasund the iceshed is situated ca. $12 \mathrm{~km}$ south of the line mentioned by Geikie (1880), in the area between Noryaragjógv and sunnaragjógv. At the centre of vestmannasund the lowest waterdepth of $40-50 \mathrm{~m}$ occurs immediately north of Noroaragjógv (fig. 9). North of Noroaragjógv roches moutonnées show a NE direction of the ice and south of Sunnaragjógv roches moutonnées show $\mathrm{SE}$ and $\mathrm{S}$ directions following the winding course of the fjord. On the Vágar side of Vestmannasund we have observed glaciated rock ground and striae but not distinct roches moutonnées. Geikie (1880) and Helland (1880), however, give northerly ice directions from roches moutonnées south of Slættanes, and Grossmann \& Lomas (1895) and Andr. Højgaard (Føroya Jarðfrøðisavn) show southerly ice movement immediately north of Marknará opposite Sunnaragjógv.

Moving WSW from the iceshed in Vestmannasund we pass the watershed and the possible iceshed in the valley between Fjallavatn and sørvágsvatn on Vágar. North of the watershed in the valley between Sørvágsvatn and Fjallavatn striae were observed by Andr. Højgaard (Føroya Jarðfrøðisavn) but no roches moutonnées. It seems likely that the iceshed was near the present watershed. The southward flowing ice stream followed the valley and the lake sørvágsvatn to Bøsdalafossur, but branched off in a westerly direction to sørvágur, and in an easterly direction to Miðvágur where it joined the ice stream from the $\mathrm{N}$-s running valley at Sandavágur.

The ice in Vestmannasund, which to the NW flowed out between Vágar and streymoy and to the SE through Vágafjørour and furt- 


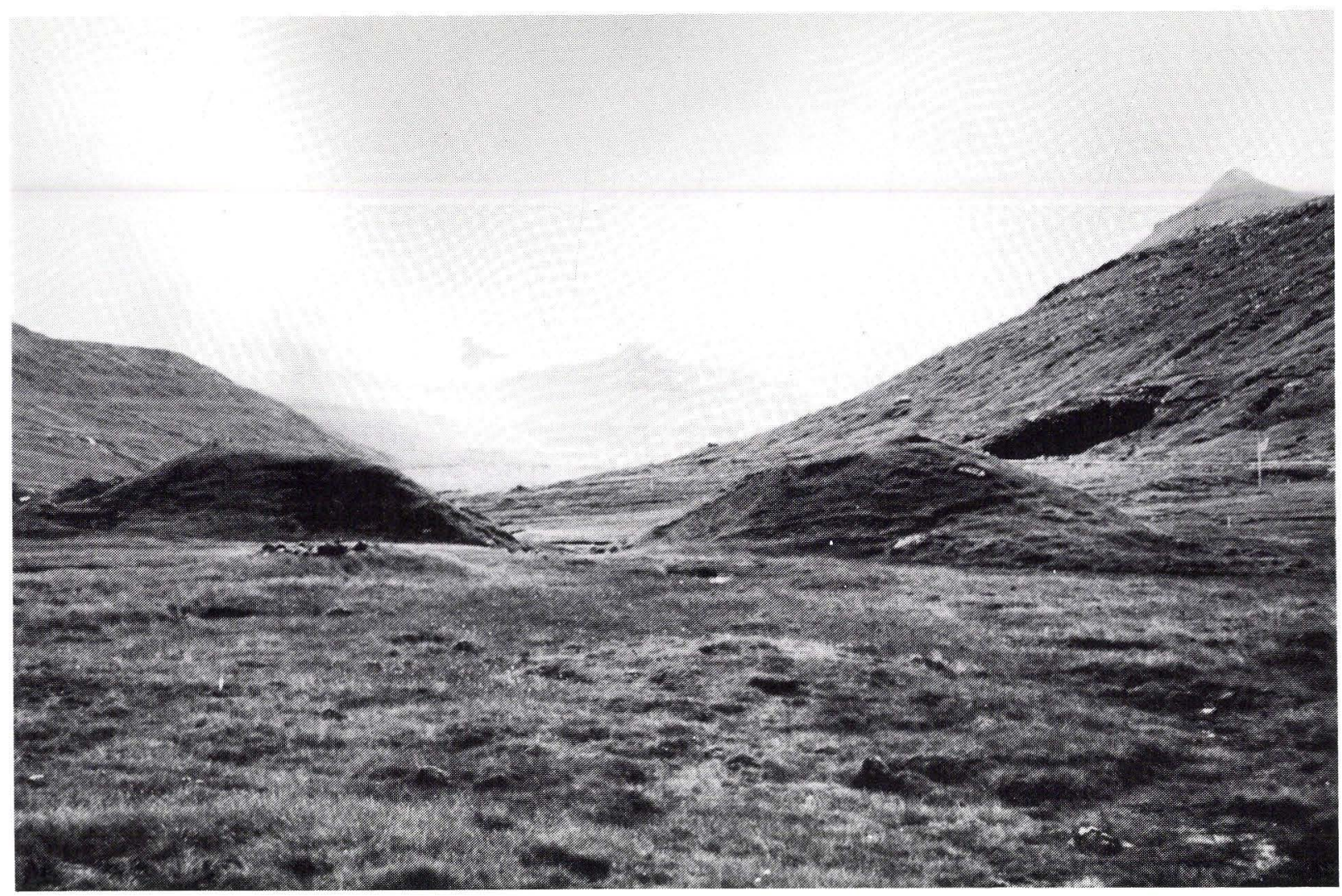

Fig. 6. Moraine hills near the iceshed in the valley between Funningsfjørður and Skálafjørơur, Eysturoy. 
her south through Hestfjørôr, came from the eastern side of Vágar and from the numerous cirques and valleys on the western side of Streymoy west of a longitudinal iceshed on Streymoy.

In Sundini, between Streymoy and Eysturoy, the south flowing ice was mainly supplied from Saksunardalur, the valley above Hósvík, Kollafjørour, Kaldbaksfjørơur on the eastern side of Streymoy, and from the valley above oyri and the area above the sill on the western side of Eysturoy. The north flowing ice passing over the strongly glaciated area at Eiơiskollux emerged from the broad valley above the village of Noroskáli, immediately north of the SW-NE trending main iceshed.

The ice from Kaldbaksfjørour, which overflowed the terrain north of Tórshavn in a SE direction, joined the ice from Havnardalur, south of Tórshavn, running $E$ into Nólsoyarfjøróur. During the maximal glaciation Nólsoy was entirely overwhelmed by ice.

East of the mountain ridge between Hornfjall in the north and Kambur in the south - a local longitudinal iceshed on western Eysturoy - the ice moved in a $N$ to $N E$ direction out from Funningsfjørour and Oyndarfjøróur and in a SE to SSE direction out from Gøtuvík, Lambavik, Rituvík and Skálafjøróur.

The ice overflowed the passes to Oyndarfjørour (Heltnin), Gøta (Gøtueiði) and Lambi (Lambareioi). At Fuglafjørour the ice bifurcated into NW and SE streams.

As mentioned earlier, the main iceshed between southward flowing and northward flowing ice in Haraldssund is situated south of the village of strond. The south moving ice from Haraldssund met with a northward flowing ice stream from Klaksvik and continued westward towards Kalsoyarfjørour. At Borooyarvik south of klaksvik, however, the ice movement was southward.

On Kalsoy striae and roches moutonnées are less distinct, so that here observations must be viewed with reservation. It can, however, be stated that from the area north of Húsar. the ice moved southward (site 7). 


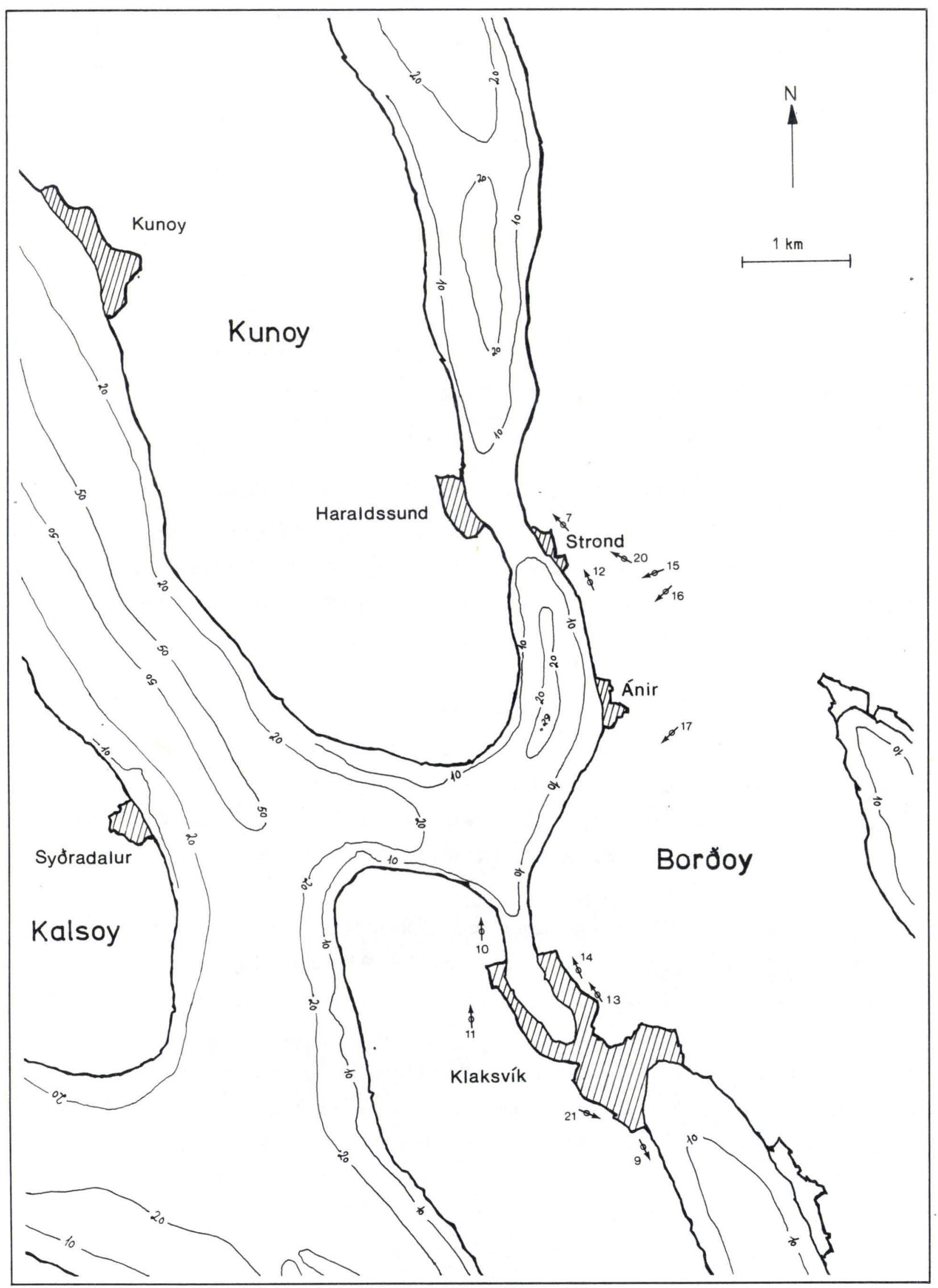

Fig. 7. Map showing bottom topography at the iceshed in Haraldssund. 


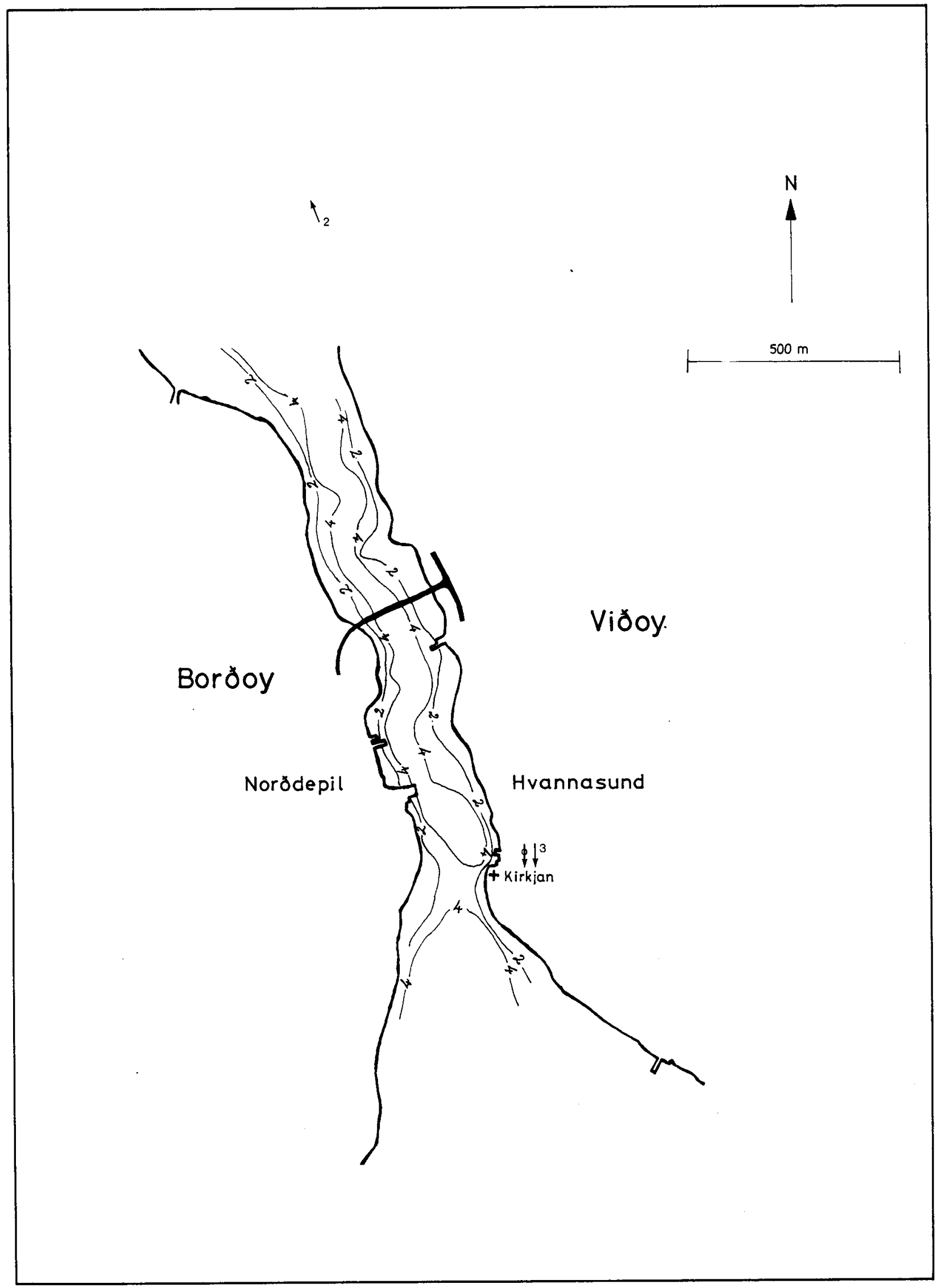

Fig. 8. Map showing bottom topograpy in Hvannasund at the iceshed between the two villages Hvannasund and Norodepil. 


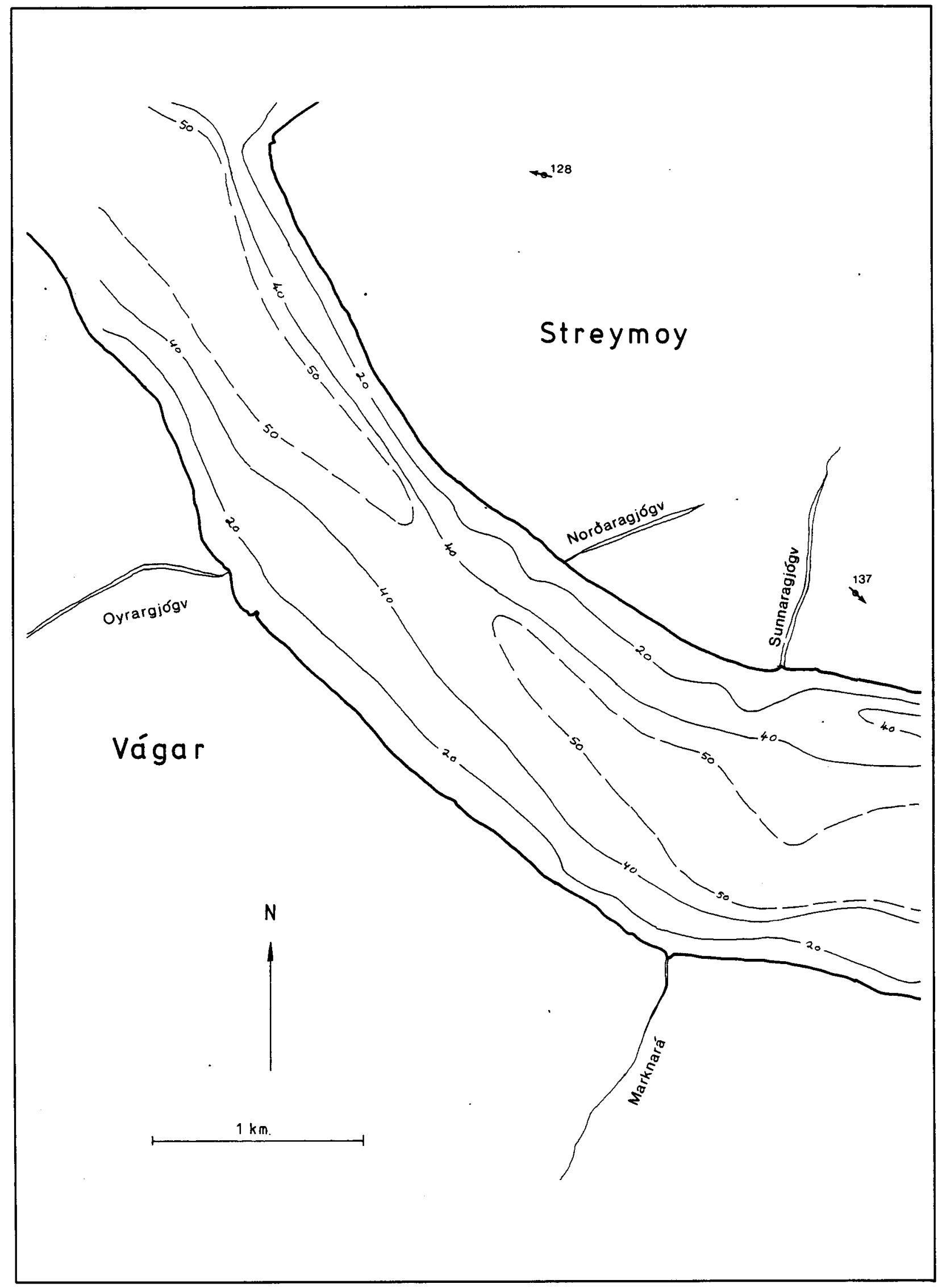

Fig. 9. Map showing bottom topography in Vestmannasund at the probable iceshed between Noróaragjógv and Sunnaragjógv. 
On Svinoy observations around the village show ice movements to the east.

THE EXTENSION OF THE ICE. Considering the horizontal extension of the ice, striae and roches moutonnées can be traced to the outermost coasts of the southern as well as of the northern islands. The position of the iceshed near the coast of western Suouroy and the remnants of cirques and valley flanks in the steep west coasts of suouroy and Vágar indicate that the ice cover extended far beyond the present coasts.

With respect to the extension of the ice cover beyond the present coastline south-east of the Faeroe Islands, more recent investigations have been made based on counts of glacial erratics from the sea bed between the Faeroe Islands and Shetland Isles. They show that the ice covered the entire Faeroe shelf in this area, but that the shelf ice was rather thin (Waagstein \& Rasmussen 1975).

Concerning the upper limit of the glaciation on the mountain sides, some heights are already mentioned in older literature. However, these must be considered as minimum heights, as the weathering in the upper parts of the mountains is highly advanced with scree covered mountain sides; striae and roches moutonnées are therefore unlikely to be preserved.

Helland (1879, 1880), Geikie (1880) and Grossman \& Lomas (1895) do not mention any heights much above $500 \mathrm{~m}$, and it has therefore been generally accepted that the ice did not exceed this altitude. However, Rudolphi (1913) mentions heights of up to $600 \mathrm{~m}$, and our own observations at Reyoafelstindur $(766 \mathrm{~m})$ on Eysturoy show that the north-west part of the mountain is glaciated, up to $20-30 \mathrm{~m}$ below the extremely rugged and weathered mountain top (fig. 10).

An almost straight NW-SE line can be drawn for the glaciation limit from the pass Eiðisskaro through the mountains Blámansfjall, Svartbakstindur, Miðalfelli, and Reyódelstindur to Nólsoy. At Eiðisskaro glaciated surfaces have been observed up to 
an altitude of about $400 \mathrm{~m}$ (Helland 1880, Geikie 1880)l) at Blámansfjall and svartbakstindur to nearly $600 \mathrm{~m}$, and at Mioalfelli to $570 \mathrm{~m}$ (Rudolphi 1913). At Reyoafelstindur the glaciation limit reaches up to about $750 \mathrm{~m}$, and it lies above the glaciated top of Nólsoy $(371 \mathrm{~m})$. Thus the highest limit of glaciation is in the area of Reyoafelstindur, and falls towards the NW. Towards the SE the limit is, as noted, above the top of Nólsoy (figs. 11 and 12 ).

On the mountains Givrufelli $(702 \mathrm{~m})$, Langafjall $(600 \mathrm{~m})$ and Sandfelli $(537 \mathrm{~m})$, running parallel to the valley saksunardalur on Streymoy, Rudolphi (1913) gives the following limits of glaciation: Gívrufelli $500 \mathrm{~m}$, Langafjall $570 \mathrm{~m}$ and Sandfelli glaciated to the top. Helland (1880) and Geikie (1880) give heights of $500 \mathrm{~m}$ for the pass between Saksun and Tjørnuvik (pass height $520 \mathrm{~m}$ ) and $450-500 \mathrm{~m}$ at the pass between Kollfjarbardalur and the valley leading down to Vestmanna (pass height $380 \mathrm{~m})$. Our observations show that the limit of glaciation on Núgvan $(667 \mathrm{~m})$ on the southern part of streymoy is 450-500 m.

1. Recent observations indicate, however, a higher upper limit than $400 \mathrm{~m}$, probably near $500 \mathrm{~m}$. Roches moutonnées at Eioisskaro point E. 


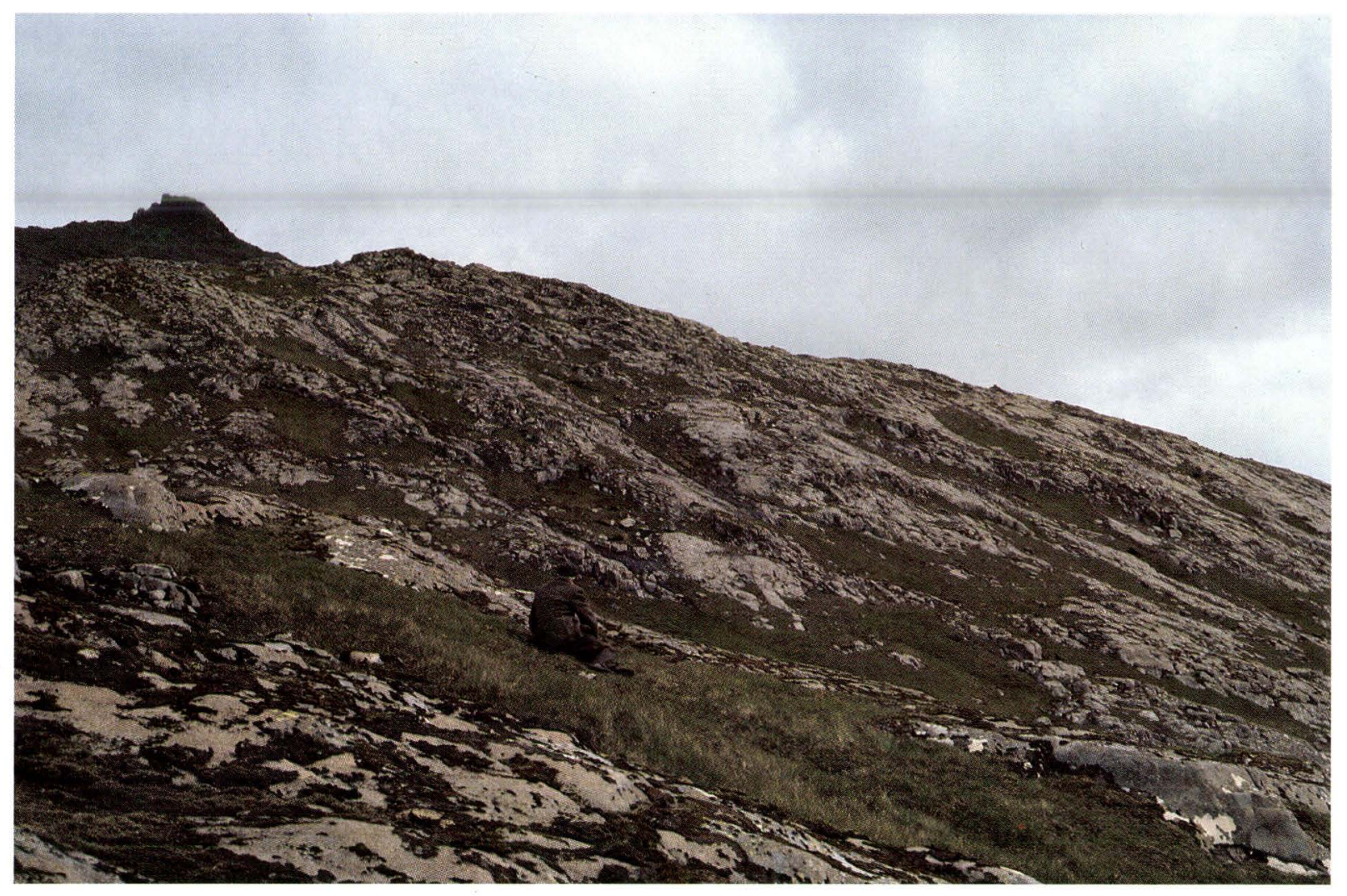

Fig.10. Glaciated sill surface on the west side of Reyðafelstindur on Eysturoy. The top of the mountain (766 m) in the background. 


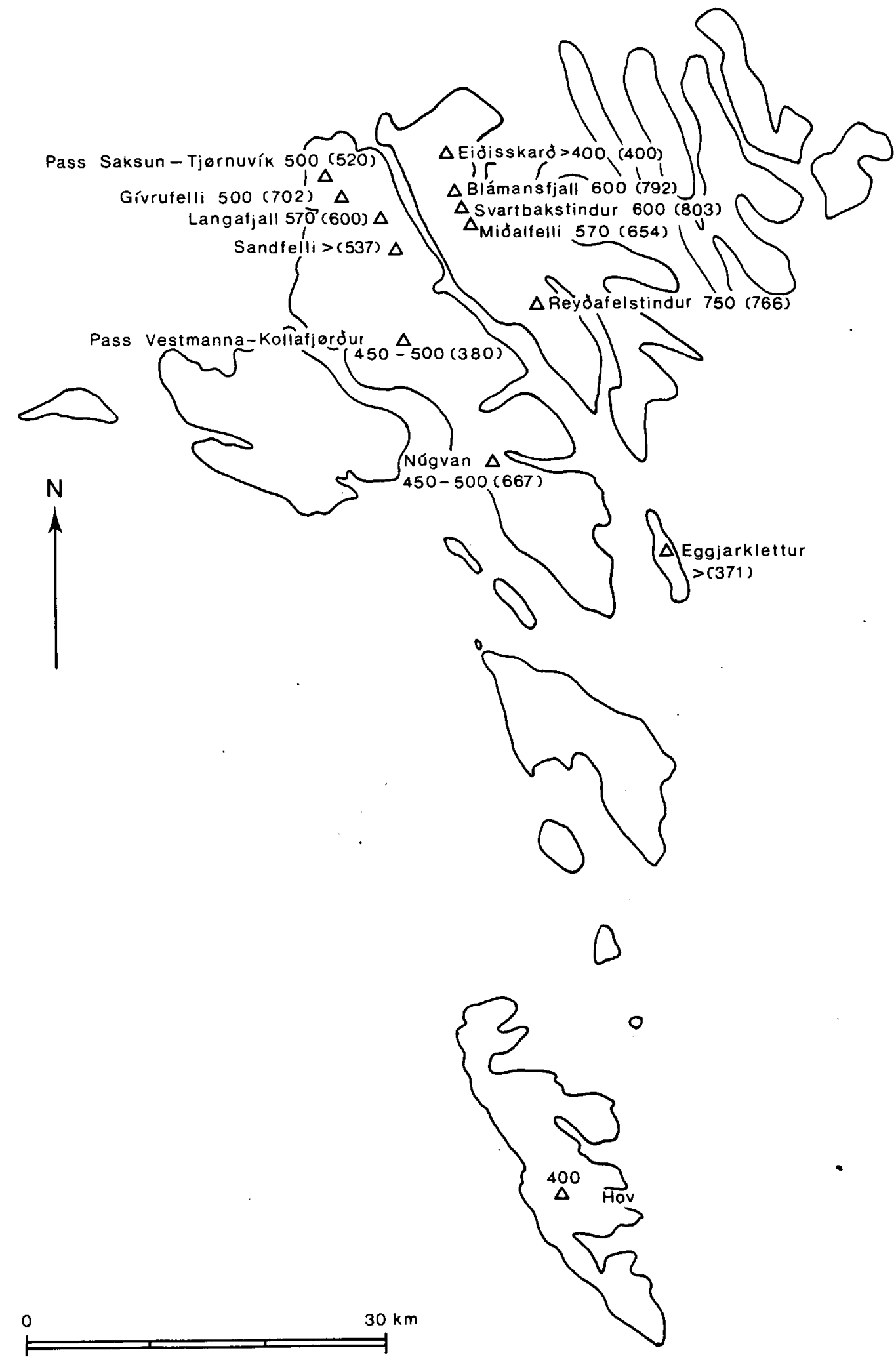

Fig.11. Map showing the upper limit of noticed glaciation on some mountain sides. Numbers in bracket: height of mountain. 


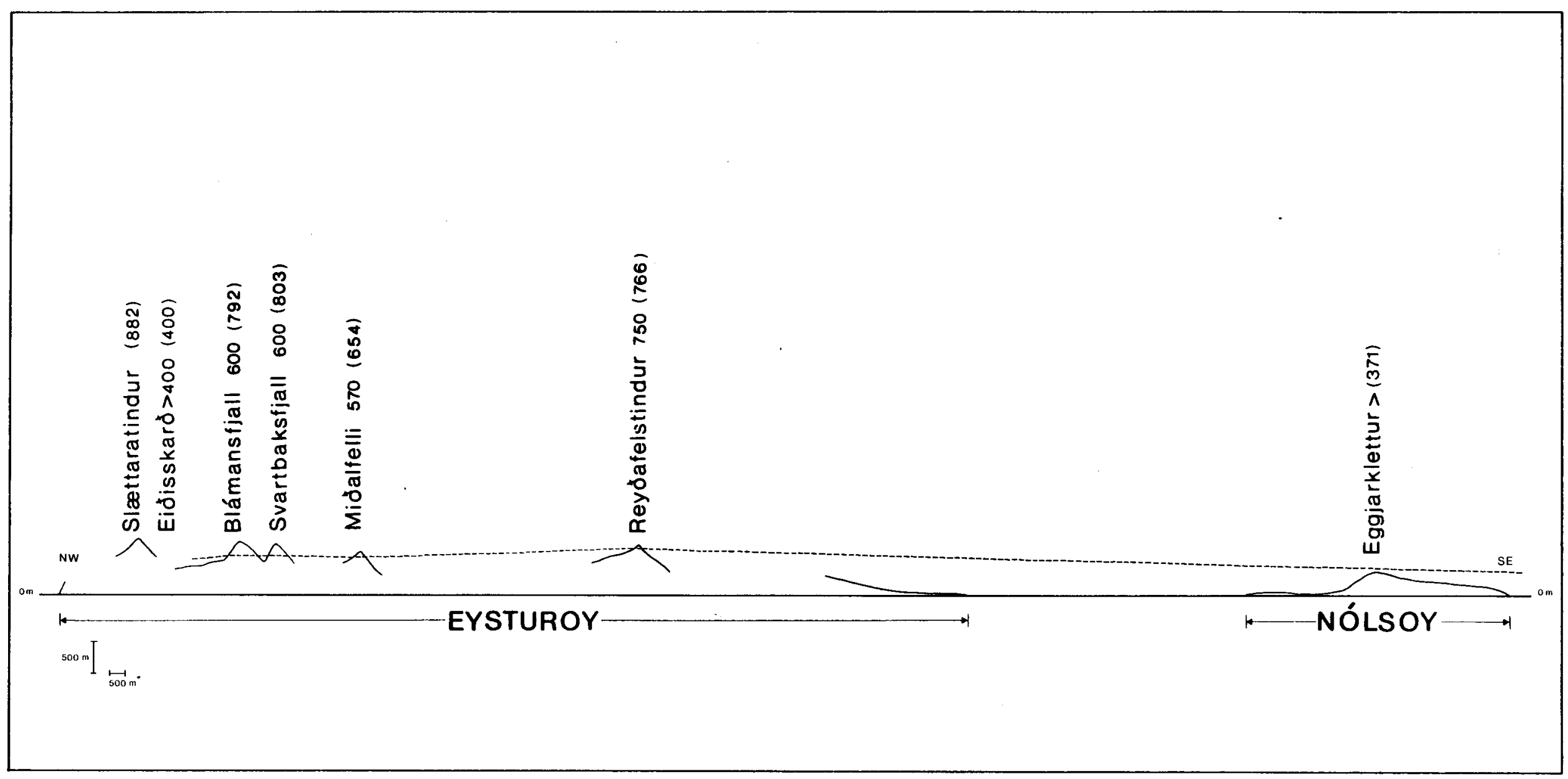

Fig.12. Section from Slættaratindur to Nólsoy showing the upper limit of noticed glaciation. 
On the southern islands striae and roches moutonnées indicate that suouroy and sandoy each had a local ice cover at least during the last glaciation. On suouroy the NW-SE running principal iceshed is situated near the west coast.

On the northern islands the undulating main iceshed from Vágar to Viroy separated NW flowing ice from SE flowing ice during the maximal glaciation. On the westernmost part of vagar the ice moved $W$ and on the northernmost islands $N E$ and $E$; in other words, as earlier pointed out, an ice movement radiating outward from the islands during an early stage of glaciation. At a later stage the ice followed the major landscape forms, the fjords and the related valleys, and at a final stage its course was determined by local terrain forms.

It is evident that the glaciers followed already existing land forms, valleys and fjords. No crossing striae or other signs indicating that the glaciers might have had other directions are found. It is therefore concluded that throughout the Ice Age the main direction of ice movement was determined by the pre-glacial major landscape morphology.

The upper limit of glaciation was at Reyoffelstindur on Eysturoy observed to be more than $700 \mathrm{~m}$.

Based on the observations of striae and roches moutonnées to the outermost coasts, of remnants of cirques and valley flanks in the steep west coasts and on counts of glacial erratics from the sea bottom between the Faeroe Islands and shetland, it is concluded that the ice reached far beyond the present coast line occupying a considerable part of the shelf.

Very little is known about interglacial deposits in the Faeroe 
Islands. A supposed interglacial deposit at Vioareiơi is drawn attention to by Noe-Nygaard (1939) and a probably secondary interglacial deposit at Borơoyarvik is described by Rasmussen (1972). 
We acknowledge the help of Tony Higgins (Grønlands Geologiske Undersøgelse) who read the manuscript and suggested linguistic improvements. We also thank the Faeroese office of public work (Landsverkfrøoingurin), Bent stouge (Geodætisk Institut) and Ragna Larsen (Geologisk Museum) for valuable drawing work. Anna Grethe Overgaard is acknowledged for photographic assistance, Kristin Johansen for typing the fair copy, and Asa Nolsøe Dam, Morten S. Andersen, Martin Heinesen, Kristian Meitil and Eyofinn Steffansson for other help. 
Allan, T., 1814: An Account of the Mineralogy of the Faeroe Islands. Trans. R. Soc. Edinb. VII. 229-267.

Berthelsen, O., Noe-Nygaard, A. \& Rasmussen, J., (eds.), 1984: The deep drilling project 1980-1981 in the Faeroe Islands. Annal. societ. scient. Færoensis, Supplem. IX. Tórshavn.

Chambers, R., 1856: Tracings of Iceland \& the Farbe Islands. London and Edinburgh. pp. 12, 23, 28.

í Dali, S., 1977: Uppmáting av vøtnum i Føroyum. Fróơskaparrit 25. 155-173.

Geikie, J., 1880: On the Geology of the Færøe Islands. Trans. R. Soc. Edinb. XXX. 217-269.

Grossmann, K. \& Lomas, J., 1895: On the Glaciation of the Faroe Islands. The Glacialist's Mag. London. pp. 15.

Hansen, A., 1982: Geomagnetiske målinger på Færøerne. Det Danske Meteorologiske Institut, København.

Helland, A., 1879: Ueber die Vergletscherung der Fürber, sowie der Shetland- und Orkney-Inseln. Z. Dt. geol. Ges. XXXI. Berlin. 716-755.

Helland, A., 1880: Om Færøernes Geologi. Geogr. Tidsskr. IV. København. 149-179.

Jørgensen, G., 1972: An area of solifluction on Suouroy, the Faeroe Islands. Bull. Geol. Soc. Denmark 21. 368-373.

Jørgensen, G. \& Rasmussen, J., 1977: Glacial striae, roches moutonnées and ice movements on suóuroy (Faeroe Islands). Fróơskaparrit 25. 174-193.

Jørgensen, G. \& Rasmussen, J., 1978: Glacial striae, roches moutonnées and ice movements on Sandoy (Faeroe Islands). Fródskaparrit $\underline{26}$. 9-21.

Jørgensen, G. \& Rasmussen, J., 1981: Glacial striae, roches moutonnées and ice movements in the southern part of streymoy and Eysturoy (Faeroe Islands). Fróoskaparrit $\underline{2} 8 \underline{2}$. 52-63.

Noe-Nygaard, A., 1939: En hærdnet Moræneaflejring ved Vióareio 
paa Færøerne. Medd. fra Dansk Geol. Foren. IX. København. 413-421.

Rasmussen, J. \& Koch, E., 1963: Fossil Metasequoia from Mykines, Faeroe Islands. Fróoskkaparrit 12. 83-96.

Rasmussen, J. \& Noe-Nygaard, A., 1969: Beskrivelse til geologisk kort over Færøerne. Danm. Geol. Unders. 1. series, 24. København.

Rasmussen, J. \& Noe-Nygaard, A., 1970: Geology of the Faeroe Islands. Danm. Geol. Unders. 1. series, 25. København.

Rasmussen, J., 1972: Mórena á Borooyarvík, sum bendir á eitt millumbil i glersetingini har norơuri. Fróoskaparrit $\underline{20}$. 54-70.

Rasmussen, J., 1982: The Faeroe Islands: geology. Monographiae Biologicae 46. The Hague. 15-35.

Rudolphi, H., 1913: Die Farber. Z. der Ges. Erdk. Berl. pp. 57. Schrøder, N., 1971: Magnetic Anomalies around the Faeroe Islands. Fróóskaparrit 19. 20-29.

Waagstein, R. \& Rasmussen, J., 1975: Glacial Erratics from the Sea Floor South-East of the Faeroe Islands and the Limit of Glaciation. Fróoskaparrit 23. 101-119. 
APPENDIX

Description of localities. 


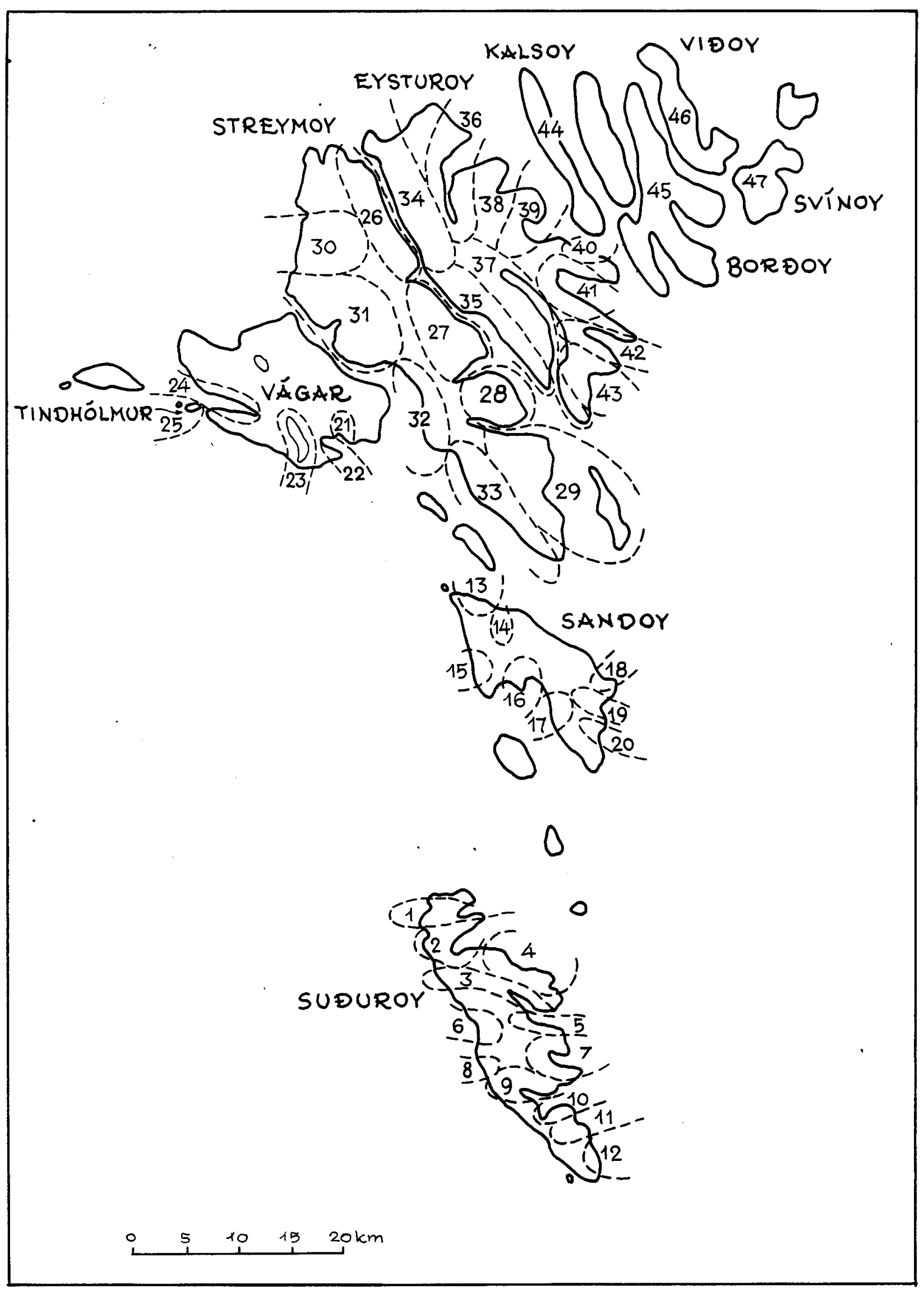


Fig.13. Division of islands into smaller areas for descriptive purposes (see appendix). Suốuroy: 1. Sandvik, 2. Hvalba, 3. Trongisvágsfjørour-Trongisvágsdalur, 4. Vatnsdalur-Hvannhagi--Froôbiarbotnur, 5. Đravík, 6. Fámjin, 7. Hov-Porkeri, 8. Botnur, 9. Vágur, 10. Lopra, 11. Vikarbyrgi, 12. Blæing-Sumba. Sandoy: 13. Skopun, 14. Noróara Hálsavatn and Heimara Hálsavatn, 15. Søltuvík, 16. Sandur, 17. Stóravatn. and Lítlavatn, 18. Skálavík, 19. Húsavík, 20. Dalur. Vágar: 21. Sandavágur, 22. Miơvágur, 23. Sørvágsvatn, 24. Sørvágur, 25. Tindhólmur. Streymoy: 26. Hvalvik-Tjørnuvík, 27. Hvalvik-Kollafjørôur, 28. Kollafjorður-Kaldbak, 29. Kaldbak-Tórshavn and Nólsoy, 30. Saksun, 31. Vestmanna-Leynar, 32. Leynar-Noróradalur, 33. Norơradalur-Kirkjubøur. Eysturoy: 34. Norôskáli-Eið̌i, 35. Norð̌skáli-Raktangi, 36. Gjógv-Funningsfjørơur, 37. Skálafjørơur, 38. Oyndarfjørŏur, 39. Fuglafjørôur, 40. Leirvík, 41. Gøta, 42. Lambi, 43. Rituvík. Noróoyar: 44. Kalsoy, 45. Boròoy, 46. Viðoy, 47. Svínoy. 
SUDUROY is the southernmost island of the Faeroe Islands, about $32 \mathrm{~km}$ long, with a maximum width of about $13 \mathrm{~km}$. It has an area of about $166 \mathrm{~km}^{2}$.

The west coast, which has an approximately linear NW-SE trend, is mostly steep and inaccessible, while the east coast is dissected by deep inlets: Sandvík, Hvalbiarfjørôur, Trongisvágsfjørôur, Hovsfjørơur and Vágsfjørơur. These inlets continue inland as broad, gently rising valleys, all of them except Hovsfjørour reaching almost to the west coast.

The dip on Suôroy is generally north-eastwards; on the southern part of the island it is to the ENE, while further north it is to the NE and NNE. On the north-western part of the island, in the area between Prestfjall and Grimsfjall, the dip is northerly.

Schrøder (1971) has demonstrated from geophysical evidence that the boundary between the lower and the middle basalt series east of suónoy continues southwards along the west coast on northern suơuroy. This boundary could imply a westerly dip west of the island. Only the lower and the middle basalt series occur on Suóluroy, where they are separated by the coal-bearing sequence.

The lower basalt series is exposed on Hvalbiareioi and in the valley south of Hvalba; north of Hvalba the middle basalt series predominates. Similarly, the lower series is found in the valley Trongisvágsdalur and over the entire island south of Oyrnafjall.

The lamellar zones on Suoruroy have, like the dykes, a predominantly NW-SE orientation, particularly in the southern part of 
the island, i.e. in the lower basalt series. They are usually broad, often strongly brecciated, and it is probable that their formation ante-dates that of the middle basalt series (Rasmussen \& Noe-Nygaard 1969, 1970).

1. Sandvik. On the most northerly part of Suouroy, a valley runs almost exactly E-W from the bay at Sandvik to the sheer cliff wall at Látragjógv on the west coast of the island. The valley floor has a more or less continuous soil cover, as may be seen along the numerous small streams. The thickest soil cover is found at the eastern end of the valley. Only on the northern valley slope have roches moutonnées been found (sites 19 and 75), and one occurence of striae, E-W (site 19). Both 10calities clearly show ice movement towards the east. On the steeper southern side of the valley the rocky ground is far more exposed, but because of the intense weathering observations are difficult.

At the western end of the valley, roches moutonnées show westward ice movement (sites 20 and 21). Glacial action can here be traced out over the most westerly cliff face, where the ice has descended a steep wall from a height of about $90 \mathrm{~m}$.

The watershed is close to the west coast, immediately east of a low WSW-ENE trending glaciated ridge crossing the valley (site 22), while the iceshed is probably situated in a $300 \mathrm{~m}$ long hummocky area east of the watershed.

Site 19. Striae (E-W). Roches moutonnées (E).

Site 20. Roches moutonnées (W).

Site 21. Roches moutonnées $(W)$. 
Site 22. Roches moutonnées (W).

Site 75. Roches moutonnées (E).

2. Hvalba. The valleys Norobergseiói and Hvalbiareiói extend westwards from the settlement of Hvalba. Norobbergseioi runs in a north-westerly direction north of Grímsfjall, while Hvalbiareioi runs south-westerly south of Grimsfjall. The mountain Grimsfjall divided a valley glacier moving from east to west. In the northern valley there is soil and grass cover, and the whole valley is cultivated. Exposures are rare, but a few roches moutonnées show stoss sides to the SE and ESE, and are thus evidence of ice movement towards the NW and WNW (sites 12 and 13).

In contrast to the northern valley, the exposed bedrock in the southern valley exhibits a well-developed roches moutonnées area, showing glacial movement towards the SW and SSW (sites 8-11). Several NE-SW striae have been seen (site 10).

On the northern side of Hvalbiarfjorour, at Hamranes and Hvitanes, roches moutonnées clearly show glacier movement to the east (sites 80 and 82 ). On the southern side of the fjord at Ranin, roches moutonnées also indicate easterly ice directions (sites 30 and 31).

At the head of the valley south of Hvalba NW-SE and NNW-SSE trending striae have been found. Roches moutonnées indicate ice movement out of the valley towards the innermost part of Hvalbiarfjørôr (sites 41-45). At the valley mouth an exposure on the eastern slope above the lagoon shows a stoss side towards the $\mathrm{SW}$ and a lee side to the $\mathrm{NE}$, indicating 
that the glacier here changed direction to the east to flow along Hvalbiarfjøróur (site 32).

The iceshed must therefore be between the localities showing westward ice movement and those showing eastward ice movement. The most probable position is close to the coast near Hvalba.•

Site 8. Roches moutonnées (SW).

Site 9. Roches Moutonnées (SSW).

Site 10. Striae (NE-SW). Roches moutonnées (SSW).

Site 11. Roches moutonnées (SW).

Site 12. Roches moutonnées (NW).

Site 13. Roches moutonnées (WNW).

Site 30. Roches moutonnées (E).

Site 31. Roches moutonnées (E).

Site 32. Roches moutonnées (NE).

site 4l. Striae (NW-SE).

Site 42. Striae (NW-SE).

Site 43. Striae (NNW-SSE).

Site 44. Striae (NNW-SSE).

Site 45. Striae (NW-SE).

Site 80. Roches moutonnées (ENE).

Site 82. Roches moutonnées (ENE).

3. Trongisvágsfjørờur - Trongisvágsdalur has a total length of about $10 \mathrm{~km}$. The fjord runs inland in a north-westerly direction, and continues westwards as a valley, Trongisvágsdalur, up to the iceshed. West of the iceshed is a cirque, Trongisvágsbotnur, which runs south-westwards to the west coast.

We11-developed roches moutonnées are found on both sides of the fjord. They show ice movement to the SE out of the fjord (sites 23, 58, 63,69 north of the fjord and $28,55,56$ south 
of the fjord). In the eastern part of the valley Trongisvágsdalur the glacier movement was almost due east (sites $14,16,17$ and 74 ).

At Botnsskard the iceshed can be defined with great accuracy. The area shows heavy glaciation with roches moutonnées showing ice movement towards the SW and WSW (sites 2-7 and 73) (Fig. 2).

Trongisvágsfjøröur

Site 23. Roches moutonnées (ESE).

Site 28. Roches moutonnées (SE).

Site 55. Roches moutonnées (SE). Striae (NW-SE).

Site 56. Roches moutonnées (SE).

Site 58. Striae (NW-SE). Roches moutonnées (SE).

Site 63. Striae (NNW-SSE). Roches moutonnées (SSE).

Site 69. Roches moutonnées (SSE).

Trongisvágsdalur

Site 2. Striae (NE-SW).
Roches moutonnées (WSW).
Site 3. Roches moutonnées (WSW).
Site 4. Roches moutonnées (SW).
Site 5. Roches moutonnées (SW).
Site 6. Roches moutonnées (SW).
Site 7. Roches moutonnées (SW).
Site 14. Roches moutonnées (E).
Site 16. Roches moutonnées (E).
Site 17. Roches moutonnées (E).
Site 73. Roches moutonnées (SW).
Site 74. Roches moutonnées (ESE).

4. Vatnsdalur - Hvannhagi - Froöbiarbotnur. 
Vatnsdalur opens to the north into Hvalbiarfjørour. The lake in the valley lies about 60 $m$ above sea-level. The valley is, however, extensively vegetation covered, and no observations of striae or roches moutonnées have been made.

At Todnes, in Hvannhagi, roches moutonnées indicate ice movement towards the ENE (site 64).

Frodbiarbotnur opens to the east. The valley floor has a uniform vegetation cover, but exposed basalt areas are seen on the flanks of the valley, up to an altitude of about $370 \mathrm{~m}$. Roches moutonnées show ice movement to the $\mathrm{E}$ (site 72), and to the SE (sites 70, 71).

\section{Hvannhagi}

Site 64. Roches moutonnées (ENE).

\section{Froobiarbotnur}

Site 70. Roches moutonnées (SE).

Site 71. Roches moutonnées (SE).

Site 72. Roches moutonnées (E).

5. Đravik, The valley at Øravik, south of Trongisvágsfjørơur, runs approximately E-W. Valdaskaro forms the iceshed between the valley and a Sw-facing cirque near Fámjin. The valley at Øravik is completely covered by vegetation, and only one site has been found with roches moutonnées, showing ice movement to the ESE (site 62). South of the bay roches moutonnées were directed to the $\mathrm{E}$ (site 57).

Site 57. Roches moutonnées (E). 


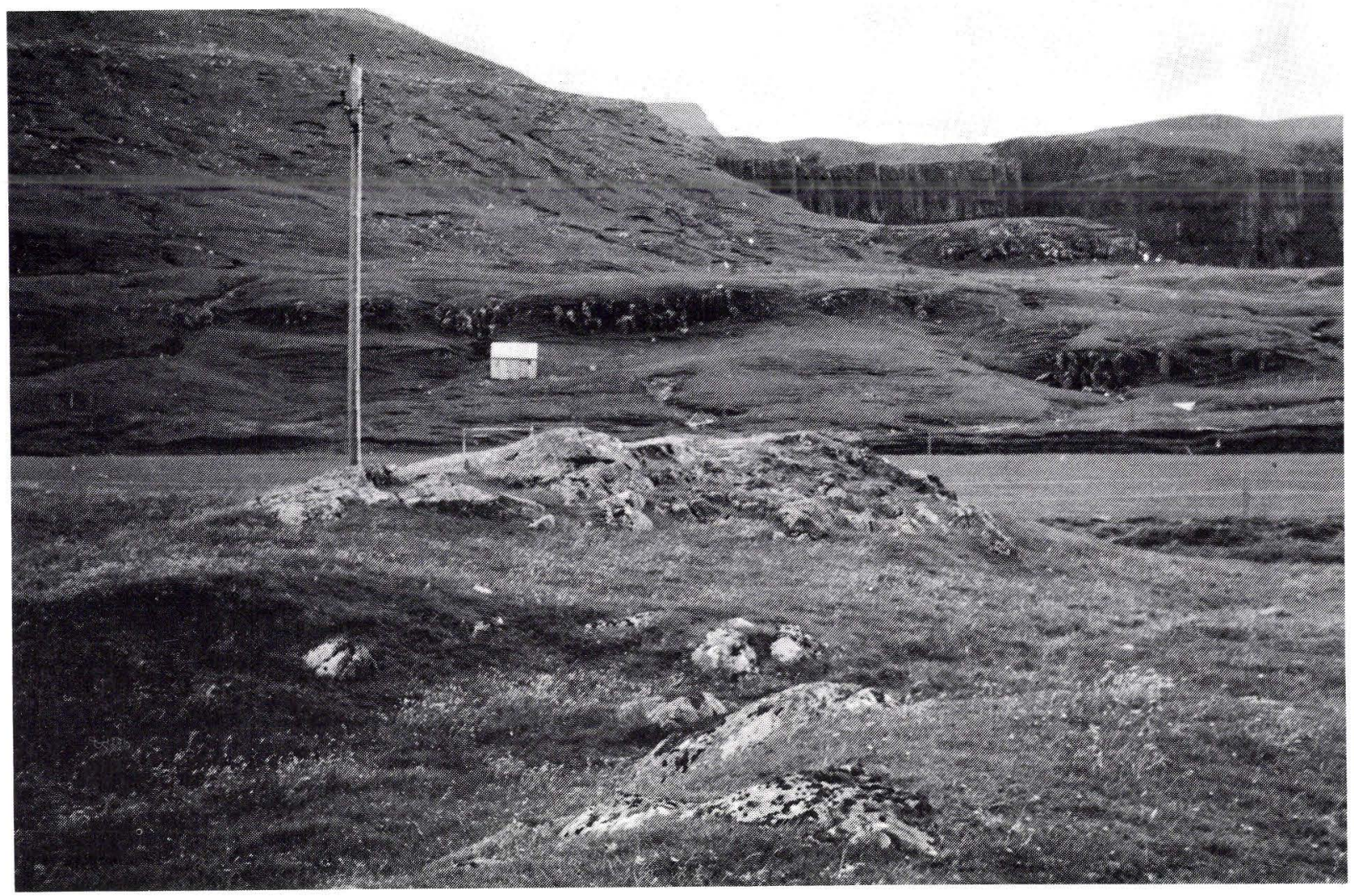

Fig.14. Roches moutonnées showing ice movement towards the $\mathrm{SW}$ (site 25) at Vágseiði, Suơroy. 
Site 62. Roches moutonnées (ESE).

6. Fámjin. In the sw-facing cirque above Fámjin, around lake Kirkjuvatn, roches moutonnées show ice movement to the SW (sites 48 and 49).

The valley south of Fámjin opens to the $\mathrm{NW}$. Areas with exposed bedrock occur as flat, glaciated basalt surfaces. Distinct roches moutonnées showing ice movement towards the NW (sites 59-61) are found along Ain Mikla near lake Rættarvatn and the lake at Bláfossur.

Site 48. Roches moutonnées (SW). Site 49. Roches moutonnées (SW). Site 59. Roches moutonnées (NW). Site 60. Roches moutonnées (NW). Site 6I. Roches moutonnées (NW).

7. Hov - Porkeri. The valley opening towards the east at the settlement of Hov is a particularly fine example of glacial action. The terrain is very uneven and hummocky, with elongated NW-SE mounds or ridges in the valley following the dominating lamellar zone system; these have acted as zones of weakness during the glaciation.

Observations of striae and roches moutonnées along Hovsá show ice movement in easterly (sites 27, 51, 52, 53 and 79), and south-easterly directions (sites 50 and 54). Easterly ice movement is also recorded by a drumlin at Porkeri (site 26).

Hov

Site 27. Roches moutonnées (E). 
Site 50. Roches moutonnées (SSE).

Site 51. Roches moutonnées (E).

Site 52. Striae (E-W).

Site 53 striae (E-W).

Site 54. Roches moutonnées (SE).

Site 79. Roches moutonnées (E).

\section{Porkeri}

Site 26. Drumlin (E).

8. Botnur. The iceshed between the Hov valley and the west-facing valley of Botnur, is formed by the crest between Borgarknappur and Hvannafelli. South-west of Ryskivatn roches moutonnées have been observed on both sides of a gravel road; ice movement was towards the sw.

Site 67. Roches moutonnées (SW).

9. Vágur. No definite roches moutonnées have been observed along the north side of Vágsfjørour because of soil and grass cover. In the vicinity of Nes (site 24), however, stoss and lee sides indicate ice movement towards the east. The exposures on the mountain slopes are clearly glaciated, but greatly weathered. On the southern side of the fjord roches moutonnées indicating ice movement towards the ESE have been found only at site 35 .

At Vágseiơi the terrain is flat and grassy. At the west end of the little lake well-formed roches moutonnées show ice movement towards the SW (site 25) (fig. 14). Glacier movement can be traced from Botndalur (site 68) towards the SE. The iceshed was probably located near the east coast. 
Site 24. Roches moutonnées (E).

Site 25. Roches moutonnées (SW).

Site 35. Roches moutonnées (ESE).

Site 68. Roches moutonnées (SE).

10. Lopra. Numerous roches moutonnées on Oyrnatangi on the west side of Lopransfjørour point SSW (site 37) towards Lopranseiơi. Lopranseioi is a continuation of Lopransfjørour towards the WSW. The terrain is strongly glaciated, and gives an overwhelming impression of having been formed by a glacier flowing WSW (site 38 ).

At Akratangi on the east side of Lopransfjørour one large exposure shows traces of ice movement to the NNE (site 78).

Site 37. Roches moutonnées (SSW). Site 38. Roches moutonnées (WSW). Site 78. Roches moutonnées (NNE).

11. Vikarbyrgi. In siglidalur, the valley above vikarbyrgi, roches moutonnées showing ice movement to the NNE and NE (sites 83 and 84) and weak striae trending NNE-SSW (site 83) have been observed. North of the stream, lower in the valley, only one site has been found with obvious roches moutonnées, which show ice movement to the ENE (site 85).

Site 83. Striae (NNE-SSW).

Roches moutonnées (NNE and NE).

Site 84. Roches moutonnées (NE).

Site 85. Roches moutonnées (ENE).

12. Blaing - Sumba. On the southernmost part of suouroy the ice movement must be assumed to have been easterly on the east coast at. Blæ- 
ing, but south-easterly at Akraberg on the southern tip of the island. The valley at the village of Sumba runs south-westwards, but has a completely grass covered surface, and no exposures were found. The iceshed was probably in the vicinity of the ridge Eggjargarour, which connects Knúkur with skálin. The ridge was formed by extensive late glacial landslides in Blæing (Jørgensen 1972). 
SANDOY. Sandoy is situated between sururoy to the south and streymoy to the north. A row of three small islands, skúvoy, Stóra Dímun and Lítla Dímun, continues the trend of the northwest coast of Sandoy. Sandoy is $23 \mathrm{~km}$ long in a NW-SE direction and $14 \mathrm{~km}$ from east to west. Its area is about $112 \mathrm{~km}^{2}$.

A broad valley runs NW-SE through the island from skopun on the north coast to Sandur on the south coast including the lakes Noroara Hálsavatn and Heimara Hálsavatn, Sandsvatn and Gróthúsvatn.

The north coast is rather steep except at the harbour at Skopun. The west coast is, for the most part, almost perpendicular up to an altitude of about $300 \mathrm{~m}$. The only inlet on the west coast is søltuvik.

The highest mountain east of the valley is Tindur, $479 \mathrm{~m}$ a.s.l., situated in the middle of the mountain ridge Reynsendi - Tindur - Patursfjall - Heidafjall. On the east coast small inlets are found at Skálavik, Húsavik and Dalur. On the southeastern part of Sandoy a valley bifurcates north-east to Skálavik and south-east to Húsavik.

The highest point west of the valley is Eiriksfjall, $411 \mathrm{~m}$ a.s.1., situated in the middle of the mountain ridge Endin Eiriksfjall - Bøllufjall.

Sandoy is mostly built up of lava flows belonging to the upper basalt series. From Skopun the chorizon - the boundary between the middle basalt series and the upper basalt series - can be traced westward and southward in the steep bird-cliffs to the east of Salthøvdi. The lava flows dip to the ENE. 
The major landscape feature is that typical of the upper basalt series, but although the step-like appearance of the slopes is evident, the hills generally appear smooth and rounded because of a dense vegetation cover. The dykes and lamellar zones have a main NNE-SSW direction, but are much fewer in number than on the northern islands.

13. Skopun. The settlement of Skopun occurs on the north coast of Sandoy. Low basalt ridges trending NNW-SSE are found west of Skopun, and are clearly smoothed and rounded at their south-eastern ends. Small, narrow NNW-SSE elongated lakes are found between the ridges (fig. 15).

Immediately around skopun, roches moutonnées indicate diverging directions of ice movement from NNE at the most easterly site (site 31) to $\mathrm{N}$ (site 32), NNW (site 33) and NW (site 34). Farther west, in the ridge-and-lake area, the movement of the glaciers was clearly towards the NNW (sites 35, 36 and 37). This is indicated not only by the stoss and lee sides of the roches moutonnées, but also by the landscape features at a larger scale, i.e. the shape of the NNW-SSE trending ridges.

Site 31. Roches moutonnées (NNE).

Site 32. Roches moutonnées (N).

Site 33. Roches moutonnées (NNW).

Site 34. Roches moutonnées (NW).

Site 35. Roches moutonnées (NNW).

Site 36. Roches moutonnées (NNW).

Site 37. Roches moutonnées (NNW).

14. Noróara Hálsavatn and Heimara Hálsavatn. Noróara Hálsavatn is bordered to the north by a slightly elevated area up to $130 \mathrm{~m}$ a.s.l., which is the highest part of the valley. 


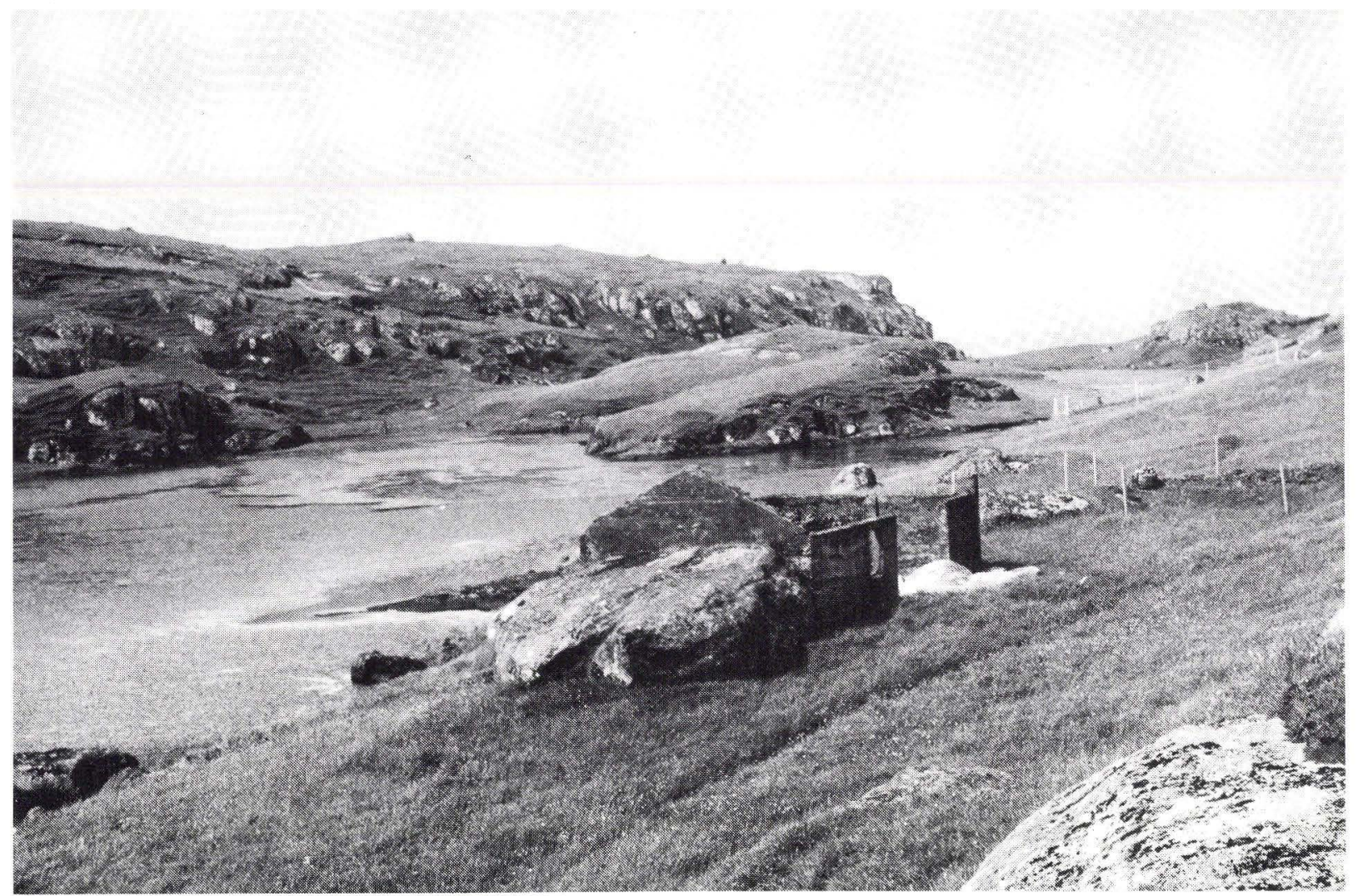

Fig.15. Basalt ridges trending NNW-SSE in the ridge and lake area west of Skopun, Sandoy. Stoss sides to the SSE. 


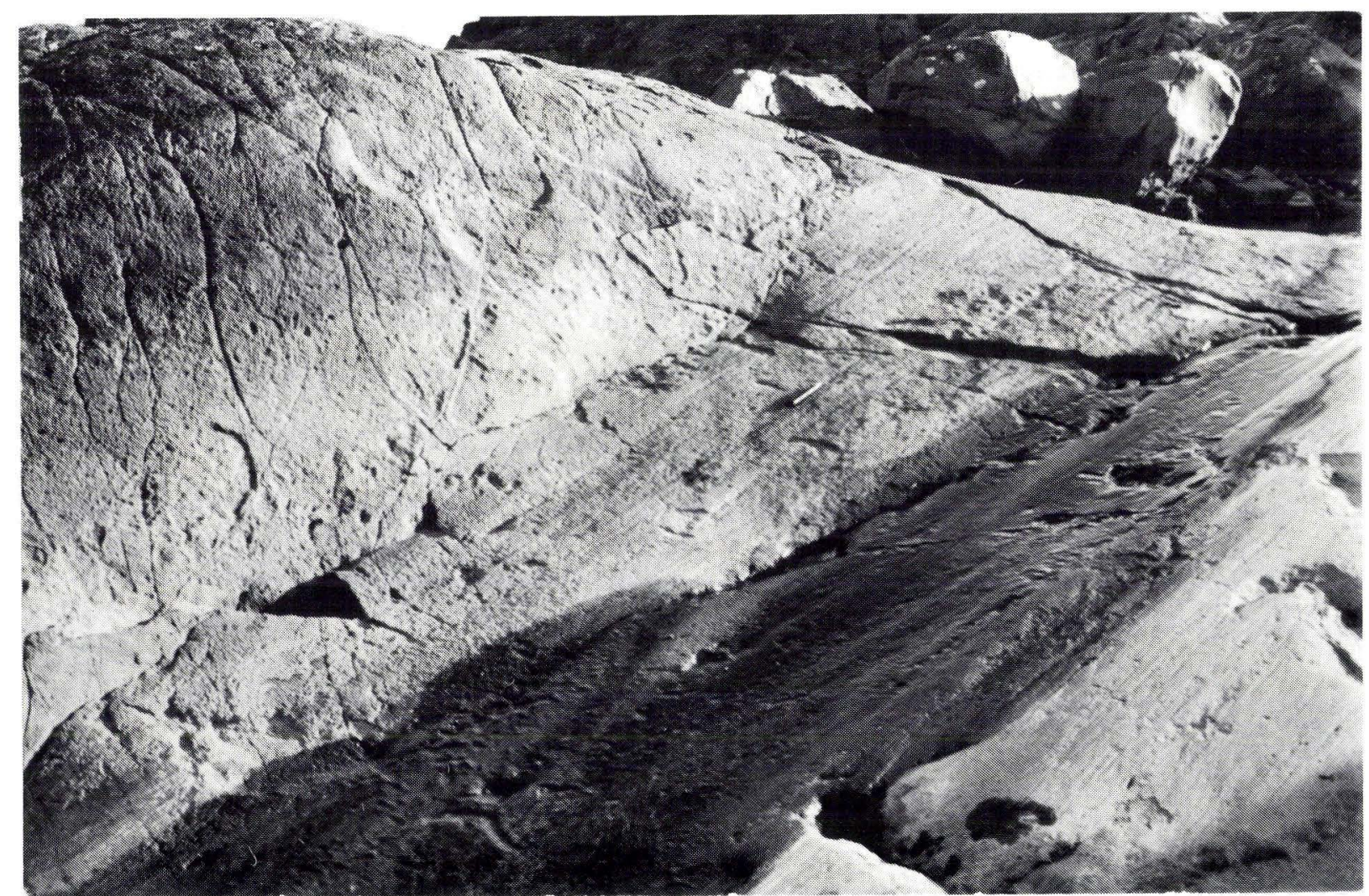

Fig.16. Strongly glaciated rock with glacial striae on the little peninsula west of the village of Sandur indicating ice movement to the SW (site 2). 
At the northern end of Noroara Hálsavatn the roches moutonnées indicate ice movement towards the $\mathrm{N}$ and $\mathrm{NNW}$ (sites 7 and 8 ). The terrain is vegetation-covered and block-strewn. At the southern end of Heimara Hálsavatn bedrock exposures show ice movement towards the $\mathrm{N}$ (site 9), but immediately to the south of this locality roches moutonnées are found indicating ice movement towards the SE (sites 10 and 11). Thus the iceshed occurs just south of Heimara Hálsavatn. The present watershed is located at site 7 at the northern end of Norôara Hálsavatn.

Site 7. Roches moutonnées ( $\mathrm{N}$ and NNW).

Site 8. Roches moutonnées (N).

Site 9. Roches moutonnées (N).

Site 10. Roches moutonnées (SE).

Site 11. Roches moutonnées (SE).

15. Søltuvik. From Søltuvik a lowland area extends in a south-easterly direction. The exposed bedrock is glaciated. Roches moutonnées indicating ice movement towards the SW were observed at the western end of Hvithamar (site 13) and north of the bay (site 40). In the valley head south of Søltuvik the roches moutonnées indicate ice movement in a NNW direction (site 41).

Site 13. Roches moutonnées (SW). Site 40. Roches moutonnées (SW). Site 41. Roches moutonnées (NNW).

16. Sandur. The settlement of Sandur lies on the east side of a small peninsula between Sandsvágur and Grótvik. The lake Sandsvatn, a little more than $2 \mathrm{~km}$ long and $2-4 \mathrm{~m}$ deep, is separated from the bay of Sandsvágur by a 400 
m broad sand barrier, the only dune landscape on the Faeroes (fig. 3). The lake Gróthúsvatn west of the peninsula is about $1 \mathrm{~km}$ long and $200 \mathrm{~m}$ wide. It is separated from the bay of Grótvík by a barrier of boulders.

In the cultivated area north-west of the village the ice direction indicated by roches moutonnées is to the SE (site 6).

The area between Sandsvágur and Grótvík is strongly glaciated right up to the edge of the approximately $40 \mathrm{~m}$ high, vertical sea-cliff to the west.

On the western side of this area roches moutonnées and striae indicate south-westerly ice movement (sites 1,2 and 26) (fig. 16).

In the area near Gróthúsvatn a few exposures indicate a southerly ice direction (sites 3, 4 and 5).

The southerly direction of glacier movement can still be traced west of Gróthúsvatn, where roches moutonnées indicate ice movement towards the SSE (site 15) and striae trending NNE-SSW (site 14). At the coast south-east of Lækjá (site 25) roches moutonnées indicate ice movement towards the SE.

Site 1. Roches moutonnées (SW). Striae (NE-SW).

Site 2. Roches moutonnées (SW-SSW). Striae (NE-SW and NNE-SSW).

Site 3. Roches moutonnées (SSE).

Site 4. Roches moutonnées (S).

Site 5. Roches moutonnées (S and SSW).

Site 6. Roches moutonnées (SE). 
Site 14. Striae (NNE-SSW).

Site 15. Roches moutonnées (SSE).

Site 25. Roches moutonnées (SE).

Site 26. Roches moutonnées (SW).

17. Stóravatn and Litlavatn. The E-W trending valley on the south-west coast of Sandoy, north of skarvanes, contains the lakes stó-. ravatn and Litlavatn. The area immediately east of the watershed (ca. $70 \mathrm{~m}$ a.s.1.) is marshy with no exposures, but around Litlavatn the bedrock is glaciated. The finest examples of roches moutonnées are found north-east of Litlavatn (sites 21 and 22), and show ice movement to the $w$. The same direction is indicated by roches moutonnées south of Litlavatn (sites 23 and 24 ).

South and east of Storavatn the bedrock is heavily glaciated. To the south roches moutonnées indicate ice movement towards the $\mathrm{SW}$ (site 27) and WSW (site 28). East of the lake the roches moutonnées show ice movement to the $w$ (site 29). The same direction is found north of Stóravatn (site 30 ).

Site 21. Roches moutonnées (W).

Site 22. Roches moutonnées $(W)$.

Site 23. Roches moutonnées (W).

Site 24. Roches moutonnées (W).

Site 27. Roches moutonnées (SW).

Site 28. Roches moutonnées (WSW).

Site 29. Roches moutonnées (W).

Site 30. Roches moutonnées $(W)$.

18. Skálavik. The bedrock is sparsely exposed in the valley at Skálavik. Near the stream stórá, a rock exposure indicates ice movement towards the ENE (site 16). On the north slope 
of Heioafjall some roches moutonnées can be seen, and indicate ice movement to the $\mathrm{NE}$ (sites 17 and 18).

Site 16. Roches moutonnées (ENE).

Site 17. Roches moutonnées (NE).

Site 18. Roches moutonnées (NE).

19. Húsavik. The valley at Húsavík is almost entirely cultivated. At Takmýrar roches moutonnées are found indicating movement to the SE (site 19), SE and SSE (site 20).

Site 19. Roches moutonnées (SE).

Site 20. Roches moutonnées (SE and SSE).

20. Dalur. No rock exposures can be seen in the valley floor and those on the slopes are highly weathered. On the northern slope near the valley head roches moutonnées indicate ice movement towards the ESE (site 39).

Site 39. Roches moutonnées (ESE). 
VAGAR. Vágar belongs, together with Tindhólmur and Mykines, to the westernmost of the northern islands. Vágar has an area of $177,6 \mathrm{~km}^{2}$, and in a WNW-ESE direction it is $22 \mathrm{~km}$ in length. A valley including Sørvágsvatn and Fjallavatn, dissects the island from Bøsdalafossur in the south to Vikar in the north. The watershed between the two lakes is about $120 \mathrm{~m}$ a.s.l. From the northern part of Sørvágsvatn a low-lying tract runs westward to sørvágur, and from the southern part of the lake a similar low-lying tract runs eastward to Mióvágur. From Sandavágur a valley runs in a northerly direction to Vestmannasund. The highest mountains are in the westernmost part of the island, and include Arnafjall, $722 \mathrm{~m}$ high. The north and west coasts are steep, sometimes nearly perpendicular, and reach altitudes of $300-400 \mathrm{~m}$, while the east coast is more gently sloping and vegetation covered.

Apart from the lowermost lava flows in the steep western mountain wall between Gásadalur and Víkar, the island consists only of lavas from the middle basalt series. The main landscape form is therefore that typical of the middle basalt series, with convex formed, often vegetation covered mountain slopes.

21. Sandavágur. There are only few exposures in the $\mathrm{N}-\mathrm{S}$ trending valley along Stórá. However, roches moutonnées were observed on both sides of the valley, on the eastern side on a partly exposed basalt flow about $70 \mathrm{~m}$ a.s.l. (site 3 ), and on the western side on a wellmarked flow about $85 \mathrm{~m}$ a.s.l. (site 4 ).

Site 3. Roches moutonnées (S)

Site 4. Roches moutonnées (S). 
22. Miovágur. Because of soil cover (cultivated areas) exposures are seen only along the coast. Roches moutonnées were observed above Prestgjógv on the southern side of the fjord about $40 \mathrm{~m} \mathrm{a.s.1.,} \mathrm{and} \mathrm{indicate} \mathrm{the} \mathrm{ice} \mathrm{direc-}$ tion to be out of the fjord (site 8 ).

Site 8. Roches moutonnées (ESE).

23. Sørvágsvatn. The valley crossing Vágar with Sørvágsvatn to the south and Fjallavatn to the north follows the predominant NW-SE direction of the fjords. Sørvágsvatn is about $6 \mathrm{~km}$ long and 500-800 $\mathrm{m}$ wide. The water level is $32 \mathrm{~m} \mathrm{a.s.l.} \mathrm{The} \mathrm{greatest} \mathrm{depths} \mathrm{of} \mathrm{water}$ are found in the northern part $(59 \mathrm{~m})$ and in the southernmost part $(45 \mathrm{~m})$, separated by a shallower area (Dali 1977). On the slopes there are only few exposures, but along the lake shore exposures are frequent. Distinct directions of striae and roches moutonnées indicate that the main course of the ice coincides with the course of the lake shore; on the eastern side (sites $5,6,7,11,12,14$ ) and on the western side (sites 9, 10). On the western side of the lake the ice branched off to Sørvágur (sites 16,17 ) and on the eastern side of the lake it branched off to Miơvágur (site 13,15$)$.

Site 5. Roches moutonnées (S).
Site 6. Roches moutonnées (SSW).
Striae (NNE-SSW)
Site 7. Roches moutonnées (SW and W).
Striae (E-W).
Site 9. Roches moutonnées (S and SSE).
Site 10. Roches moutonnées (S).
Site 11. Roches moutonnées (SSE).
Site 12. Roches moutonnées (SSE).


Site 13. Striae (NW-SE).

Site 14. Roches moutonnées (SSE).

Site 15. Roches moutonnées (ESE).

Site 16. Roches moutonnées (SSW, SW and WSW).

Site 17. Roches moutonnées (W).

24. Sørvágur. Sørvágsfjørơur faces WNW. Several cirques open into the fjord. both on the northern and on the southern side. In the inner part of sørvágsfjørour (sites 1,18 ) and in the outer part (site 2) roches moutonnées and striae show ice movement out of the fjord.

Site 1. Striae (NW-SE).

Site 2. Striae (WNW-ESE).

site 18. Roches moutonnées (WNW).

25. Tindhólmur. The south side of Tindhólmur is almost vertical and reaches a height of 262 $m$; the vegetation covered north side forms the continuation of the southern flank of sørvágsfjørður.

Site 1. Striae $(E-W)$. Roches moutonnées (W). 
STREYMOY. Streymoy is situated between Vágar and Eysturoy. It 'has an area of $373,5 \mathrm{~km}^{2}$, a length in a NW-SE direction of 47 $\mathrm{km}$, and a greatest width of $15 \mathrm{~km}$. It is separated from Vágar by Vestmannasund and from Eysturoy by Sundini.

The northern part of streymoy is cut by a broad valley, Saksunardalur, about $10 \mathrm{~km}$ long, and the southern part by another broad valley, Kollfjaróardalur, which is about $6 \mathrm{~km}$ long.

The highest mountains are found in the northern part of the island (Koppenni, $790 \mathrm{~m}$ ). The mountains to the south are generally lower, with the exception of Skælingsfjall $(763 \mathrm{~m})$.

The only significant bays on the west coast are those at Vestmanna and Saksun. The north-west coast is very steep, and sometimes more than $500 \mathrm{~m}$ high. The east coast of streymoy is sheltered, like the west coast of Eysturoy. Steep coastal cliffs occur only to the north-west and south-east where the coast is exposed to the attack of the sea. On both sides of the sound separating the two islands the terrain slopes gently towards the coast. Erosion has been insignificant since the Ice Age, on recently exposed bedrock, striae and roches moutonées can be found down near the shoreline.

In addition to a few small bays, two deep fjords occur, Kollafjørður and Kaldbaksfjørður.

The northern part of the island is, like Vagar, exclusively built up of lavas belonging to the middle basalt series. In the central part the middle basalt series is mostly overlain by the upper basalt series. On the southern part, and on Nólsoy, only the upper basalt series is present. The thick streymoy sill is well exposed on the west side of the island. Dykes and lamellar 
zones occur most frequently in a zone across the northern part of the island.

26. Hvalvík - Tjørnuvík. At site 54 , about 5 $\mathrm{km}$ to the north of Hvalvik, roches moutonnées indicate ice movement towards the $N$. Striae with a N-S trend are also found on a conspicuously grooved erosional remnant at the roadside a little further north (site 55). From the valley at Haldarsvik the ice moved ESE into sundini (site 56), but immediately north of Haldarsvík roches moutonnées show that the ice moved due $N$ (site 60 ) and then followed the course of the fjord towards the NNW (sites 57 and 58). From the valley at Tjørnuvik a glacier moved towards the $\mathrm{NE}$ and joined the ice flow from sundini (site 59).

Site 54. Roches moutonnées (N).

Site 55. Striae (N-S).

Site 56. Roches moutonnées (ESE).

Site 57. Roches moutonnées (NNW).

Site 58. Roches moutonnées (NNW).

Site 59. Roches moutonnées (NE).

Site 60. Roches moutonnées (N).

27. Hvalvik - Kollafjørour. In the valley Saksunardalur, north-west of Hvalvik, roches moutonnées near Ravnagilsá (site 132) show ice movement towards the SE.

On the valley slopes south-west of the village of Hósvik, roches moutonnées indicate ice movement towards the ENE and NE (sites 63 and $64)$.

Around Kjalnestangi the low-lying coastal area is distinctly glaciated. Immediately north of Kjalnestangi some roches moutonnées indicate 
ice movement to the SSE (site 61). Further north (site 62), both roches moutonnées and glacial striae show movement in the same direction.

Near the head of Kollafjørôur roches moutonnées show SE ice direction out of the fjord (site 95).

Site 61. Roches moutonnées (SSE).

Site 62. Roches moutonnées (SSE). Striae (NNW-SSE).

Site 63. Roches moutonnées (ENE and NE). Site 64. Roches moutonnées (NE). Site 95. Roches moutonnées (SE). Site 132. Roches moutonnées (SE).

28. Kollafjørour - Kaldbak. The coastal slopes are rather steep, except at the village Kaldbak on the south coast. From the village Kaldbak a NW-SE trending valley rises to an altitude of $300 \mathrm{~m}$; small lakes and numerous ridges are elongated NW-SE. Numerous glaciated exposures can be seen on the slopes east and west of Høgadalsá; striae, roches moutonnées and elongated hillocks indicate ice movements to the SE (sites 66, 67, 86, and 87).

The high-lying valley of Týggjará is also characterized by the presence of elongated, heavily glaciated hills (roches moutonnées), clearly indicating ice movement towards the SE and SSE (sites 88, 89 and 90). Some exposures show glacial striae running NW-SE (site 88 ). Two large lakes (the largest a little more than $500 \mathrm{~m}$ long) and several smaller ones (many elongated NW-SE) can be seen in the valley at about $260 \mathrm{~m}$ a.s.l. The lakes are situated in rock basins. 
Along the north coast of Kaldbaksfjørour, roches moutonnées and striae have been observed only between the village Kaldbak and Kaldbaksnes. West of the landing-place at Kaldbak roches moutonnées indicate ice movement in an ESE direction (site 71) and on Mógvanes, a small flat, rocky foreland situated where the NW-SE trending valley of Høgadalsá opens into the fjord, both roches moutonnées $S E$ and striae NW-SE can be seen (site 70). At Kaldbaksnes striae run E-W and ESE-WNW (sites 68 and 69). North of Kaldbaksnes glacial striae trending NNW-SSE were observed at site 91.

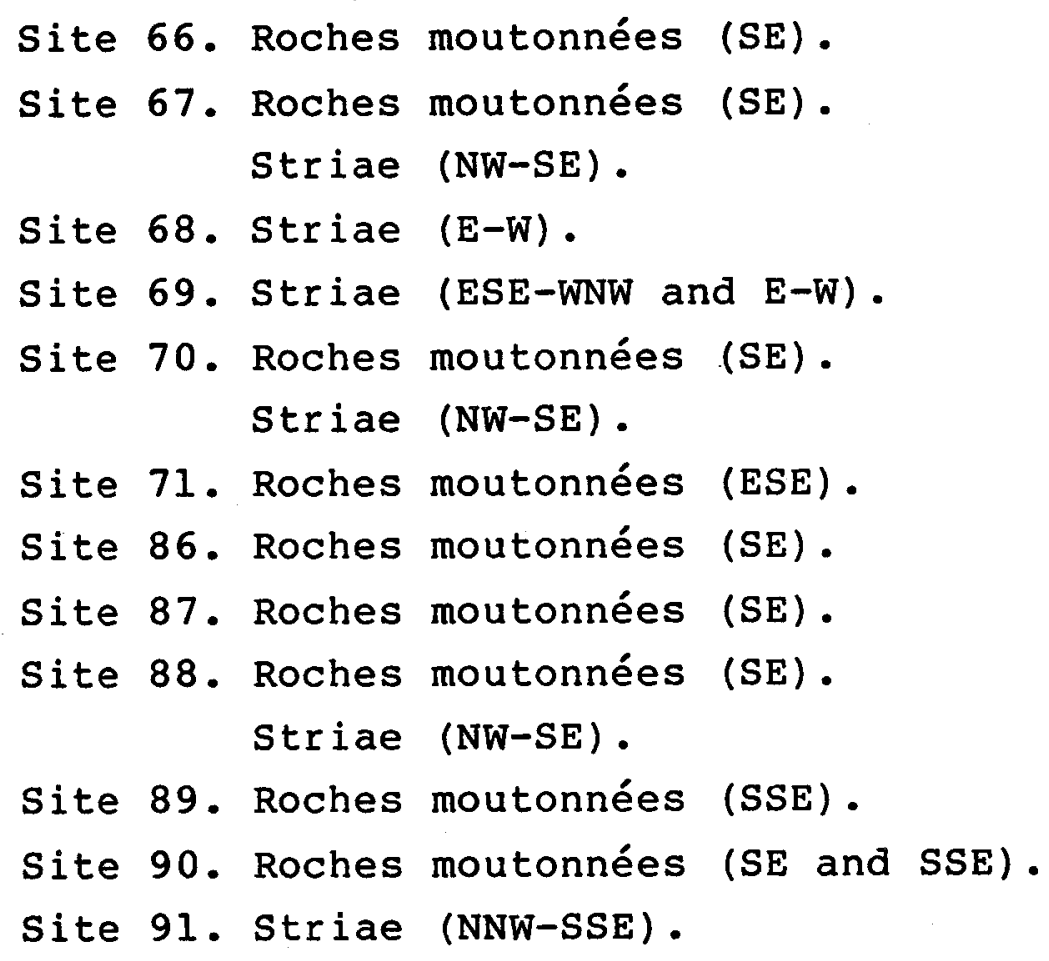

29. Kaldbak - Tórshavn and Nólsoy. The terrain between Kaldbaksfjørour and Tórshavn is uneven, and marked by $\mathrm{NW}-\mathrm{SE}$ trending topographic features: water courses, gullies and elongated hillocks.

On the south coast of Kaldbaksfjørour the striae and roches moutonnées are parallel to the winding course of the fjord. North-west of 


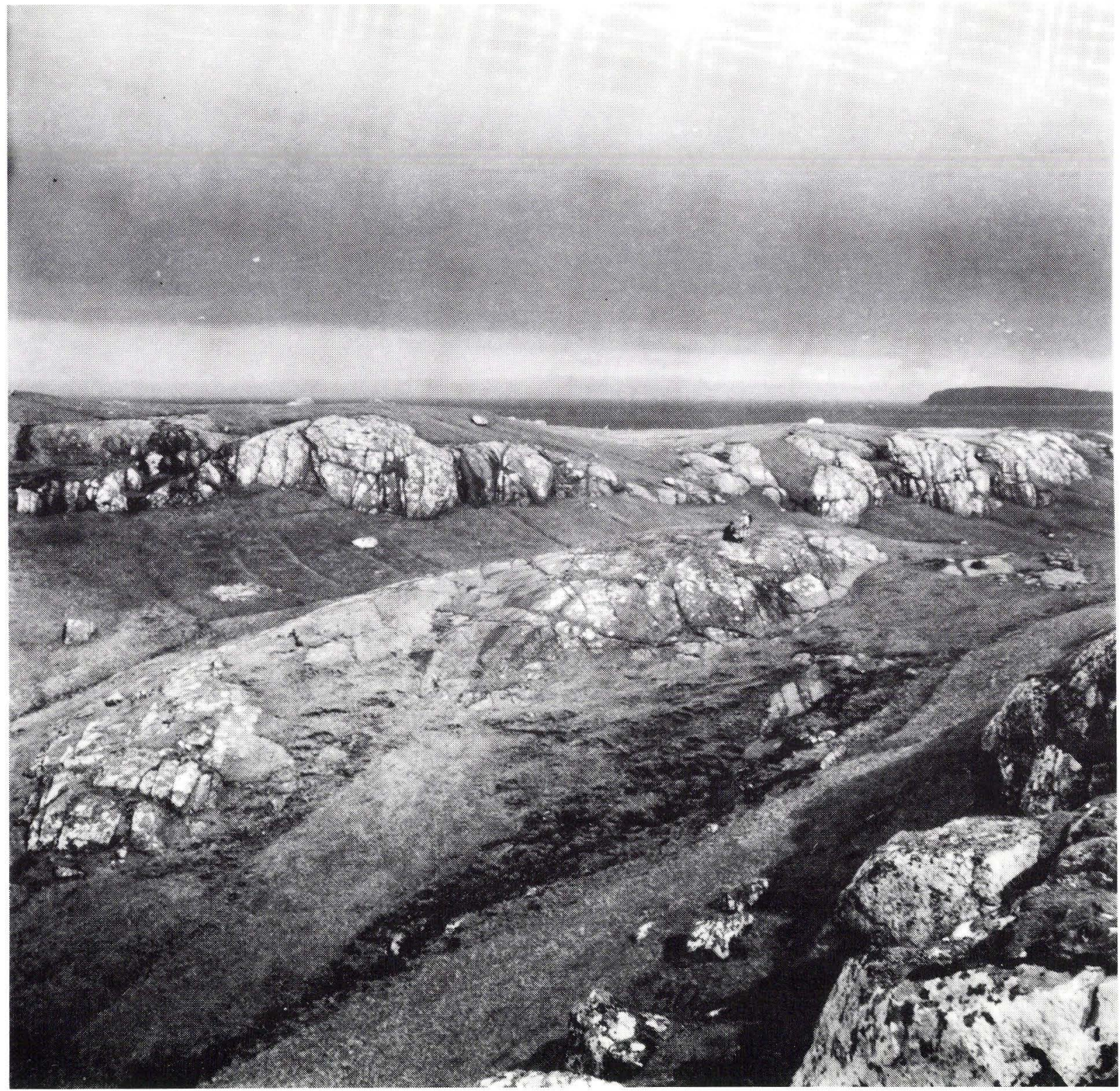

Fig.17. Heavily glaciated bedrock can be seen in the NW-SE trending gullies through the basalt benches east of the village of Sund, Streymoy (sites 75, 77 and 79). 
82 
the village of sund roches moutonnées and striae indicate ice movement to the ESE (sites 80 and 85 ), and at sund, towards the $E$ (site 65). From the valley above sund a local ice stream flowed NNE into Kaldbaksfjøróur (site 15). Immediately before the south coast of Kaldbaksfjørour turns towards the south-east, the roches moutonnées point $E$ (sites 76 and 78) while north of Hvitanes they point ESE (sites 7-10), and at Hvitanes SE (sites $11-13)$.

East of Sund at the entrance of the fjord heavily glaciated bedrock can be seen in gullies through the basalt benches showing directions ESE to SE (sites 75, 77 and 79) (fig. 17).

Between Hvitanes and Hoyvík NNW-SSE running striae (site 14) and at Hoyvík SE to SSE directed roches moutonnées were observed (site 24 and 25 ).

Observations on glacial striae and roches moutonnées within the boundaries of the oldest part of the capital Tórshavn are among the earliest observations on glacial phenomena in the Faeroe Islands (Chambers 1856, and later authors).

In the outskirts of Tórshavn, where bedrock has been blasted in order to make way for the expanding town, a great number of glaciated exposures have now been destroyed, but in the oldest part of the town there are still several well-preserved roches moutonnées, some of them forming the foundations of the old houses.

Fine roches moutonnées are to be seen at the 
ancient fort (site 17), indicating ice movement towards the SSE and SE and behind the fort the same directions are seen all over the old town (sites 18, 23, 26, 27, 28, 29, 30, 31 and 32).

In the inner part of the valley Havnardalur roches moutonnées show ice movement towards SSE and ESE (sites 16 and 20), and in the outer part of the valley in an easterly direction (sites 21 and 22). North of Glyvursnes striae are oriented NW-SE (site 46), but south of Glyvursnes roches moutonnées show direction towards SSW following the coast (site 10l).

Nólsoy is separated from streymoy by Nólsoyarfjørdur. The lower, northern part $(74 \mathrm{~m}$ a.s.1.), and the higher southern part (Eggjarklettur, $371 \mathrm{~m}$ ), are connected by an isthmus. The west side is heavily glaciated to the summit, roches moutonnées point ESE (sites 2, 3 and 4 ). The east side is steep and inaccessible.

In the northern part of Nólsoy (site 5), and on the isthmus (site 1) roches moutonnées showing the same direction ESE were observed.

Kaldbak - Tórshavn

Site 7. Roches moutonnées (ESE).
Site 8. Roches moutonnées (ESE).
Striae (ESE-WNW).
Site 9. Roches moutonnées (ESE).
Striae (ESE-WNW).
Site 10. Roches moutonnées (ESE).
Striae (ESE-WNW).
Site 11. Roches moutonnées (SE).
Striae (NW-SE).




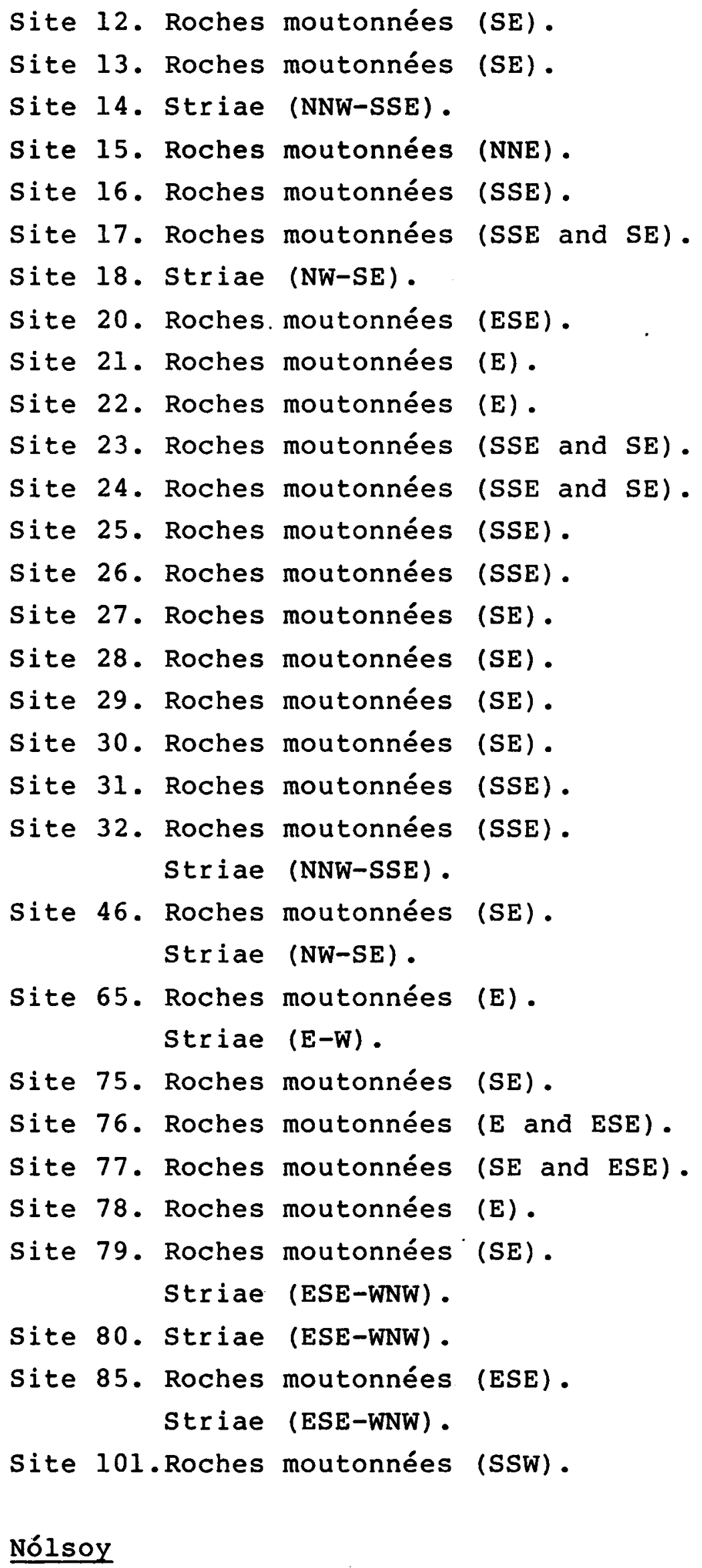

Site 1. Roches moutonnées (ESE). 
Site 2. Roches moutonnées (ESE).

Site 3. Roches moutonnées (ESE).

Site 4. Roches moutonnées (ESE).

Site 5. Roches moutonnées (ESE).

30. Saksun. From Saksun a long broad valley, Saksunardalur, leads south-eastwards in the direction of Hvalvik. Immediately west of the village of Saksun a hanging valley trends northward along Gellingará, and on the south side of saksunardalur another hanging valley, Heljardalur, trends SW, terminating in a cleft on the west coast. There are only few exposures in the valleys.

North-west of the watershed in Saksunardalur roches moutonnées very clearly indicate ice movement towards the NNW (sites 92 and 93). Farther to the west, near the lagoon at Saksun, the direction is WNW (site 94). On a higher level, at Breioa on the south side of Saksunardalur, the roches moutonnées point NW (site 115).

In the valley of Gellingará fine exposures of roches moutonnées point to the SSW and S (sites $124,125,126$, and 127).

Heljardalur opens into Saksunardalur at $200 \mathrm{~m}$ a.s.1. above a high steep slope. At the edge of this slope roches moutonnées show ice movement to the $E$ (site 116), but farther to the west in the valley the roches moutonnées point to the WSW (sites 117, 118 and 119).

Near the west coast, in a tributary valley to Heljardalur, roches moutonnées show that the ice followed the valley trend towards the SSW (sites 120,121 ). 
On a higher level north-west of Heljardalur glaciation shows local ice movements towards the NW (site 122) and SE (site 123).

Site 92. Roches moutonnées (NNW).
Site 93. Roches moutonnées (NNW).
Site 94. Roches moutonnées (WNW).
Site 115. Roches moutonnées (NW).
Site 116. Roches moutonnées (E).
Site 117. Roches moutonnées (WSW).
Site 118. Roches moutonnées (WSW).
Site 119. Roches moutonnées (WSW).
Site 120. Roches moutonnées (SSW).
Site 121. Roches moutonnées (SSW).
Site 122. Roches moutonnées (NW).
Site 123. Roches moutonnées (SE).
Site 124. Roches moutonnées (SSW).
Site 125. Roches moutonnées (SSW).
Site 126. Roches moutonnées (SSW).
Site 127. Roches moutonnées (S).
Striae (N-S).

31. Vestmanna - Leynar. The central part of Streymoy, between Vestmanna and Dalsnipa, faces Vestmannasund. Vestmannasund separates Vágar and Streymoy. The mountains surrounding the village of Vestmanna attain a height of about $300 \mathrm{~m}$. From the hills to the west, north and east of Vestmanna the ice moved down towards the bay into Vestmannasund.

In Gassádalur south of Vestmanna roches moutonnées and striae indicate ice movement towards the WNW (sites 128, 129), coincident with the trend of the valley.

From the innermost part of the bay the valley Heljareyga runs eastwards and the valley Fossádalur northwards. 
North of the water reservoir in Heljareyga roches moutonnées indicate ice movement along the valley towards WSW (site 84). South-west of Heljareyga roches moutonnées point WNW near the coast (site 130), and to the $W$ somewhat higher up (site 131).

At the embankment of the northern water reservoir in Fossádalur roches moutonnées indicate ice movement towards SSW (site 83), while south of the southern reservoir in the valley the direction is due south (site 82). On the southfacing slope east of Fossá striae and roches moutonnées have a WSW direction (site 81), like the striae west of Fossá (site 105).

The Dala valley north of Vestmanna runs wSw and terminates in a deep gjógv (gorge) at the steep west coast. Roches moutonnées directions in the valley follow the main stream (sites $102,103,104)$.

In the area Hægstafjall - Melin the numerous observed roches moutonnées show directions coincident with local slopes (sites 107, 108, $109,110,111,112$ ).

In the area west of Gjógvará the roches moutonnées point to the ESE and SSE (sites 106, 113), at the coast they point SE (site 114), while farther to the south they point westwards (site 134).

Between Vestmanna and Kvivik the two large gorges, Norơaragjógv and Sunnaragjógv, terminate in Vestmannasund. 
On the coastal slope east of Sunnaragjógv roches moutonnées indicate ice movement $\mathrm{SE}$ through Vestmannasund (site 137).

In the $N-S$ trending valleys at the village Kvívík roches moutonnées and striae show ice movement following the valleys (sites 33, 34, 35).

From the south-eastern end of Mjávuvøtn in Kollfjaroardalur the ice moved towards the NW (site 96) and WSW (site 97) to lake Leynavatn. Roches moutonnées in the valley north of Leynavatn also show directions towards the lake (sites 40,41 ).

In the narrow valley between Leynavatn and the coast roches moutonnées and striae show that the ice here moved towards the WSW (site 98), SW (sites 99, 100), SSW (sites 37, 38) and S (site 36 ) out into Vestmannasund.

Site 33. Roches moutonnées (SW).

Site 34. Roches moutonnées (S). Striae (N-S).

Site 35. Striae (NNW-SSE).

Site 36. Roches moutonnées (S).

Site 37. Striae (NNE-SSW).

Site 38. Roches moutonnées (SSW).

Site 40. Roches moutonnées (S).

Site 41. Roches moutonnées (SSE).

Site 81. Roches moutonnées (WSW).

Striae (WSW-ENE) .

Site 82. Roches moutonnées (S).

Site 83. Roches moutonnées (SSW).

Site 84. Roches moutonnées (WSW).

Site 96. Roches moutonnées (NW).

Site 97. Roches moutonnées (WSW).

Site 98. Roches moutonnées (WSW). 
Site 99. Striae (NE-SW).

Site 100. Roches moutonnées (SW).

Site 102. Roches moutonnées (WSW).

Site 103. Roches moutonnées (SSW).

Site 104. Roches moutonnées (WSW).

Site 105. Striae (WSW-ENE).

Site 106. Roches moutonnées (ESE).

Site 107. Roches moutonnées (WNW and $W$ ).

Site 108. Roches moutonnées (WNW).

Site 109. Roches moutonnées (W).

Site 110. Roches moutonnées (WNW).

Site 111. Roches moutonnées (NNE).

Site 112. Roches moutonnées (ESE).

Site 113. Roches moutonnées (SSE).

Site 114. Roches moutonnées (SE).

Site 128. Roches moutonnées (WNW).

Site 129. Striae (WNW-ESE).

Site 130. Roches moutonnées (WNW).

Site 131. Roches moutonnées (W).

Site 134. Roches moutonnées (W).

Site 137. Roches moutonnées (SE).

32. Leynar - Nororadalur. The large streymoy sill dominates the landscape between Leynar and Nororadalur. The sill extends from the top of the mountain sátan $(621 \mathrm{~m})$ in the north to the summit of Núgvan $(667 \mathrm{~m})$ in the south, a distance of about $9 \mathrm{~km}$. It outcrops over an area of about $13 \mathrm{~km}^{2}$. At stórareyn between Sátan and skælingsfjall, in Gjáarbotnur between skalingsfjall and sandfelli and in the valley Oman fyri stígar, erosion has been sufficiently deep that large areas of the sill surface have been exposed.

At Stórareyn the exposed sill surface appears as hilly terrain; the sill here forms rows of elongate NW-SE trending hillocks or ridges with vegetation and small lakes in fissures 


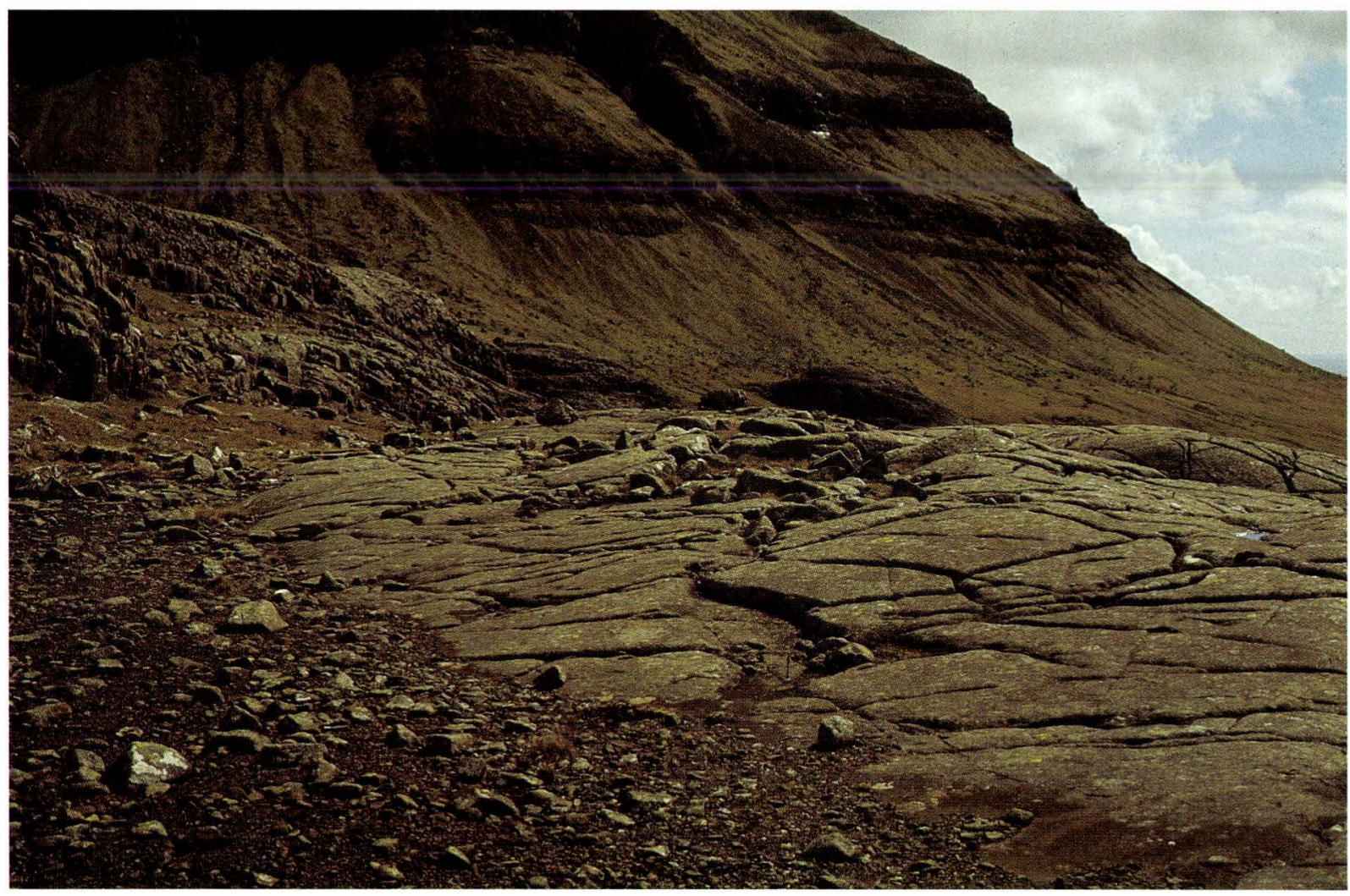

Fig.18. The glaciated sill surface at Stórareyn, Streymoy (site 44), with distinct stoss sides to the east and lee sides to the west. 
and depressions between the hillocks. The sill surface is heavily glaciated with distinct stoss sides facing the east and lee sides towards the west (fig. 18). The trends of the glacial striae are E-W, WSW-ENE and WNW-ESE (site 44 ).

Immediately west of Skælingsskaro, the pass between Sátan and Stórareyn, both roches moutonnées and striae indicate that the ice moved due $W$ (sites 42,43 ).

South of stórareyn, closer to the coast, roches moutonnées and striae show evidence of ice movement to the SSW (site 135). This can also be observed farther south at an altitude of about $50 \mathrm{~m}$ (site 136). Thus the ice movement at stórareyn was westerly, turning to the south through Vestmannasund.

In Gjáarbotnur the exposed sill surface is heavily glaciated. Like that of stórareyn the sill surface is hillocky with vegetation and lakelets in fissures and depressions. The directions of roches moutonnées and striae converge towards the center of the valley in the direction of Vestmannasund (site 47).

The southernmost part of the sill area in the valley Oman fyri stigar is bordered to the north-east by two cirques. The westernmost part of the valley is covered with vegetation, whereas the easternmost part is made up of the glaciated sill, which here is exposed to the top of the mountain Núgvan. Here, too, the sill terrain is hummocky with small lakes here and there. At the south side of the mouth of the valley the direction of roches moutonnees and striae is $\mathrm{N}-\mathrm{S}$ (site 72 ). 
Site 42. Roches moutonnées (W).

Site 43. Roches moutonnées $(W)$. Striae (E-W).

Site 44. Striae (E-W, WSW-ENE, WNW-ESE).

Site 47. Roches moutonnées ( $W$ and WSW).

Striae (NE-SW, ENE-WSW, E-W, ESE-WNW, SSE-NNW) .

Site. 72. Roches moutonnées (S). Striae (N-S).

Site 135. Roches moutonnées (SSW). Striae (NNE-SSW).

Site 136. Roches moutonnées (SSW).

33. Nororadalur - Kirkjubøur. The southernmost part of Streymoy from Dalsnipa to Kirkjubøur faces Hestfjørour. Between Dalsnípa and Kirkjubøur the valleys Nororadalur, Syoradalur, Fossdalur and Mígandalur open into Hestfjorour. At the villages of Nororadalur, Syoradalur, Velbastaóur and Kirkjubøur the coast is accessible, but between the valleys grasscovered slopes terminate in coastal cliffs.

Two cirques open into Nororadalur, the northern one opening towards the south-west, the southern one towards the west. South of the stream in Nororadalur striae and roches moutonnées point due $W$ (site 48). Upward in the northern cirque roches moutonnées indicate ice movement towards WSW (site 51) and SW (site 53). Striae trend NNE-SSW (site 52).

Two cirques open into syoradalur in the same directions as those in Nororadalur. At the village roches moutonnées south of the stream point WNW (site 49), and north of the stream to the W (site 50).

In Fossdalur striae trend NE-SW and roches 
moutonnées point SW (site 73) to Hestfjørour, towards the sound between Hestur and koltur.

In Mígandalur (site 19) and at Breioá south of Velbastaour (site 74 ) roches moutonnées point towards the SW.

The only observation along the coast of the southernmost part of streymoy was at Kirkjubøur. Here well preserved roches moutonnées indicate ice movement towards the SSE (site 45).

Site 19. Roches moutonnées (SW).

Site 45. Roches moutonnées (SSE).

Site 48. Roches moutonnées $(W)$.

Site 49. Roches moutonnées (WNW).

Site 50. Roches moutonnées $(W)$.

Site 51. Roches moutonnées (WSW).

Site 52. Roches moutonnées (SSW). Striae (NNE-SSW).

Site 53. Roches moutonnées (SW).

Site 73. Roches moutonnées (SW). Striae (NE-SW) .

Site 74. Roches moutonnées (SW). 
EYSTUROY. EYsturoy has and area of $286,33 \mathrm{~km}^{2}$. It is $35 \mathrm{~km}$ from NE to $S W$ and has a greatest width of about $18 \mathrm{~km}$. To the west it is separated from streymoy by Sundini, and to the east from Norooyar by Djúpini and Leirviksfjørour. The gently sloping west coast is sheltered like the east coast of streymoy. Some of the highest mountains of the Faeroes are found in the western part of the island (Slattaratindur, $882 \mathrm{~m}$ ). The east coast is fan-shaped, indented with several fjords opening in varying directions from $N E$ in the northern part to $S E$ in the southern part of the island. The valley between skálafjørour and Funningsfjorour trends NW-SE, parallel to the main fjord direction, and divides the island into a western and an eastern part.

The middle basalt series dominates in the northern part of the island, the upper series only occupying the tops of the mountains. In the southern part of the island the upper basalt series dominates. The large Eysturoy sill occupies the west central part of the island.

34. Noroskáli - Eiơi. North of Noróskáli (site 52) roches moutonnées show ice movement to WNW and a little further north to the NW. At Krossur (site 14), further north again, the direction is NNW, while west of Eioisvatn (site 39) roches moutonnées show NNW direction.

The isthmus of Eioi, mentioned previously, with its heavily glaciated rock surfaces, deep furrows and prominent roches moutonnées, clearly indicates ice movement towards the $N$ (figs. 19, 20). The locality was mentioned by 
Allan (1814) and Chambers (1855). Allan refers to the abraded rock surface and remarks that: "the rock appears to be worn down by the friction of heavy bodies" (p. 18); and later: "It would be curious to investigate, whether this smoothness on the sides of the mountains could be traced to any external cause, such as that which has been observed by Sir JAMES HALL, on Corstorphine Hill, and other parts of this country, indicating the passage of heavy bodies along the surface. Near Eide, I observed a very remarkable example of this description. There the rock was scooped and scratched in a very wonderful degree, not only on the horizontal surface, but also on a vertical one, of thirty to forty feet high, which had been opposed to the current, and presented the same scooped and polished appearance with the rest of the rock, both above and below." ( $p$. $38-39$ ).

Chambers' description of the locality is in accordance with Allan's, but Chambers mentions the polished rocks, grooves and striae as derived from ice coming from the north. Geikie (1880) refers to Allan and Chambers, but points out that the ice did not come from the north, as stated by Chambers, but on the contrary from the south, moving towards the north.

In agreement with Geikie, our investigations show that the rock surfaces on the north-west side of the isthmus are clearly glaciated (site 15), and deeply furrowed with glacial grooves trending NNE-SSW. More faint striae trending from $\mathrm{N}-\mathrm{S}$ to $\mathrm{NNE}-\mathrm{SSW}$ can be seen. Roches moutonnées clearly show that the ice movements have been towards the NNE or $N$. On the 


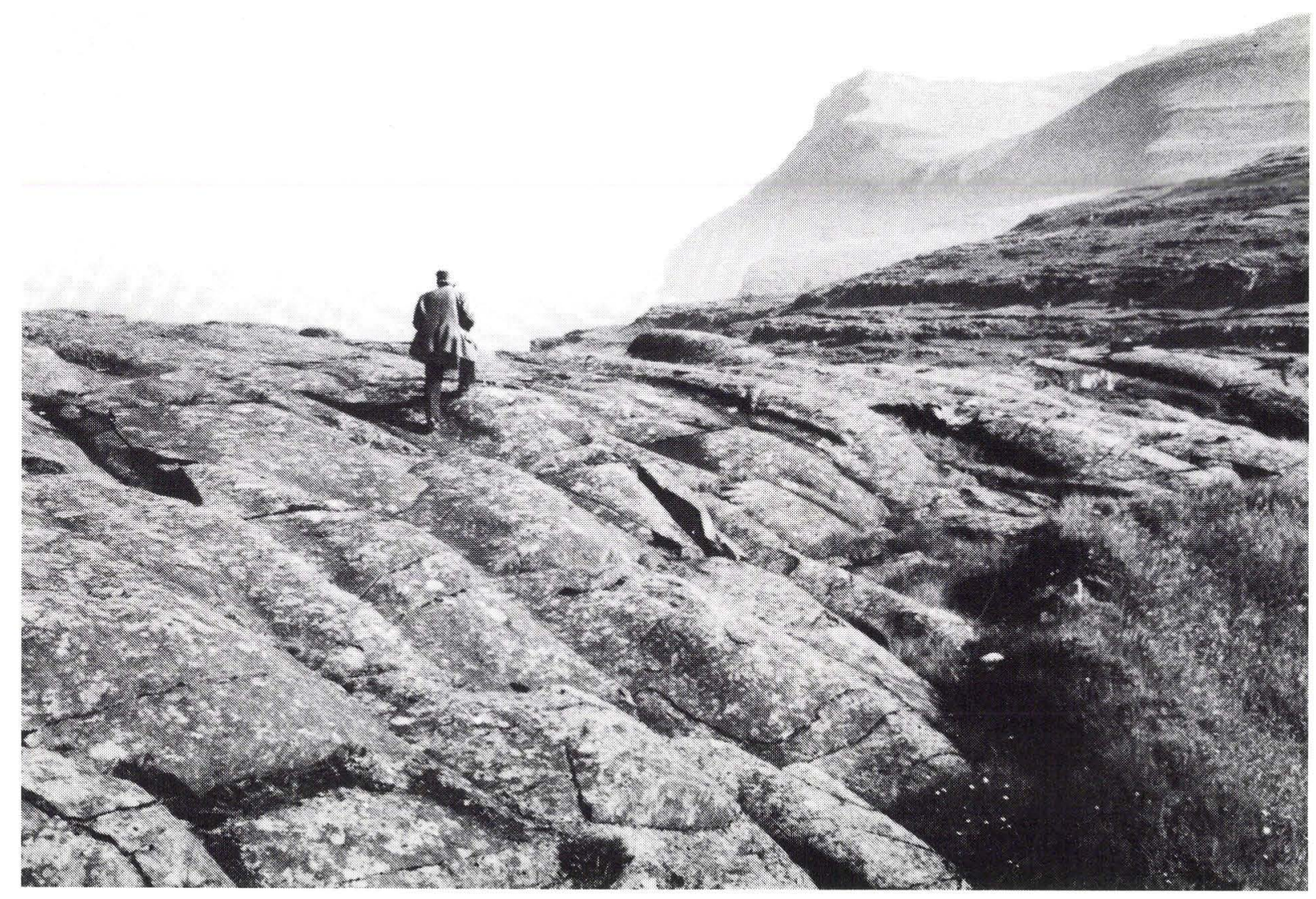

Fig.19. Glacial furrows at the village of Eioi, Eysturoy (site 15), already recognized and described by Allan (1814) and Chambers (1855). 


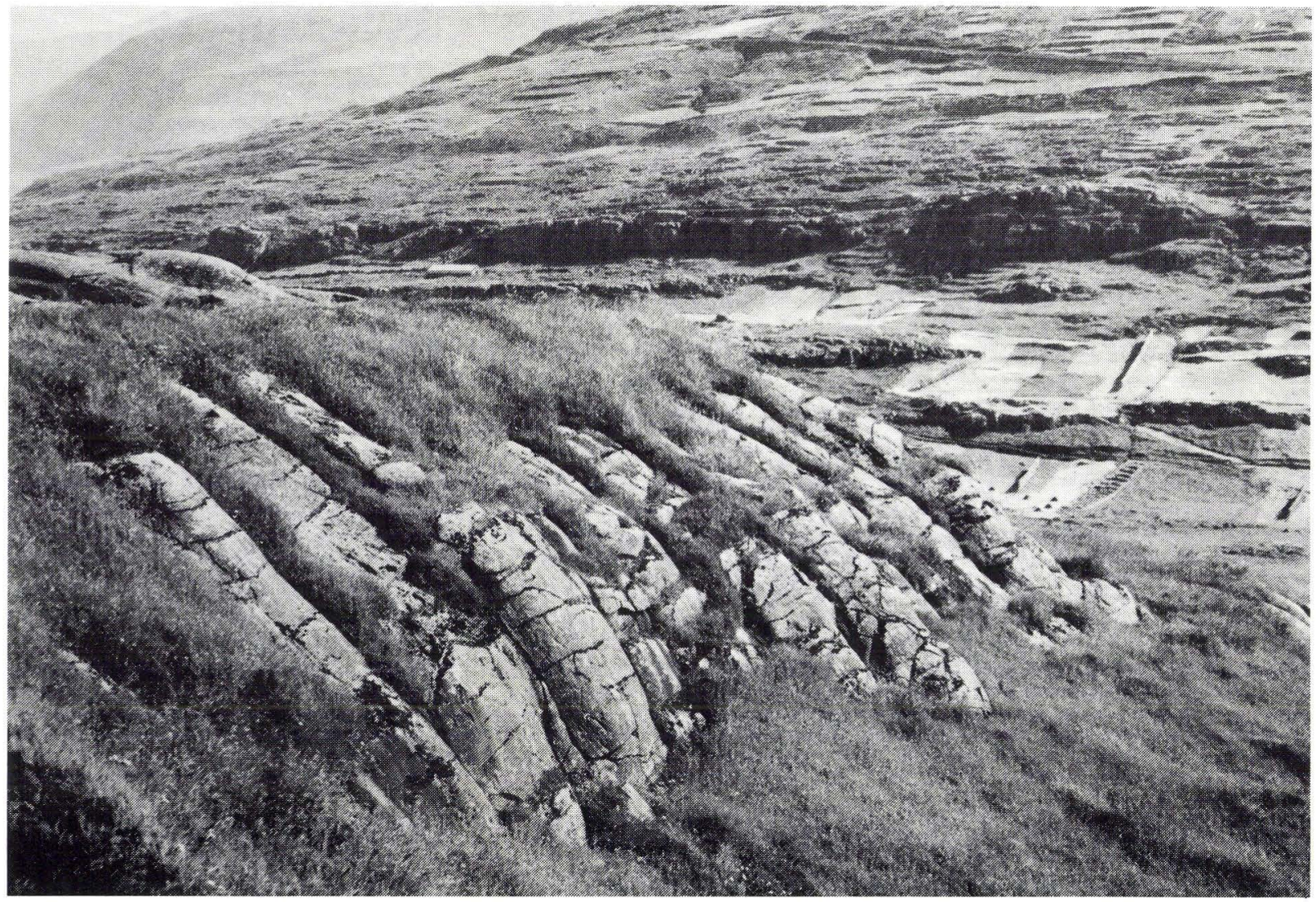

Fig.20. Glacial furrows at the village of Eioi, Eysturoy (site 15), already recognized and described by Allan (1814) and Chambers (1855). 
east side of the isthmus (site 19) roches moutonnées show ice movement to the NNE.

Site 14. Roches moutonnées (NNW). Site 15. Roches moutonnées (NNE). Striae, grooves (NNE-SSW and N-S).

Site 19. Roches moutonnées (NNE). Site, 39. Roches moutonnées (NNW). Striae (NNW-SSE).

Site 52. Roches moutonnées (WNW, NW).

35. Noroskáli - Raktangi. The Eysturoy sill outcrops over a distance of $6,5 \mathrm{~km}$ from Nøvin in the north to Reyorfelstindur in the south. It has an area of about $16 \mathrm{~km}^{2}$. A great part of the sill surface is exposed and clearly glaciated, especially in the valley at Oyri, in the lower part of Breioabotnur and to the south in the area between Veðranes and Reyoafelstindur. The Eysturoy sill is coarser grained and more strongly weathered than the basalt of the streymoy sill. Distinct glacial striae are rare, but there are well-developed roches moutonnées. The sill surface is often hummocky with stoss and lee sides, e.g. in the landscape south-east of oyri.

The upper part of the valley above the village of Oyri consists of the exposed, strongly glaciated sill surface. At an elevation of about 180-200 $\mathrm{m}$ roches moutonnées with almost due west direction are seen on both sides of the stream. Southward from here direction of the roches moutonnées becomes more and more southerly (site 51). In Breioábotnur, north of the little lake Breiðávatn, numerous roches moutonnées with SSW direction and striae (NNE-SSW) are seen (site 50). In the southern area between Blásendi - Eggin - Reyơafelstin- 
dur (site 49) the sill is widely exposed. The ice direction was here towards sundini. At an elevation of about $450 \mathrm{~m}$ the roches moutonnées north-west of Blásendi point to the SW and WSW and a little further north striae trend NNE-SSW. The mountain crest Eggin between $\mathrm{xxx}$ Reyoafelstindur and Halgafelstindur has been extensively glaciated, and the $766 \mathrm{~m} \mathrm{high}$ Reyðafelstindur shows evidence of glaciation almost to the top (Fig. 10).

On the southern part of Eysturoy, south-west of the village of strendur, roches moutonnées indicate ice movement to the SSE (sites 2-5), and striae trend $\mathrm{N}-\mathrm{S}$ (site 18).

Site 2. Roches moutonnées (SSE).

Site 3. Roches moutonnées (SSE).

Site 4. Roches moutonnées (SSE).

Site 5. Roches moutonnées (SSE).

Site 18. Striae (N-S).

Site 49. Roches moutonnées (SW, WSW). Striae (NNE-SSW).

Site 50. Roches moutonnées (SSW). Striae (NNE-SSW).

Site 51. Roches moutonnées (W, WSW, SW, SSW, SSE) .

36. Gjógv - Funningsfjorour. In the valley above the village Gjógv on the north-western part of Eysturoy; both roches moutonnées and striae indicate ice movement towards the NE (site 20).

In the valley east of the village Funningsfjørour roches moutonnées occur about $400 \mathrm{~m}$ a.s.l., and point wSW towards the inner part of Funningsfjørour (site 53). 


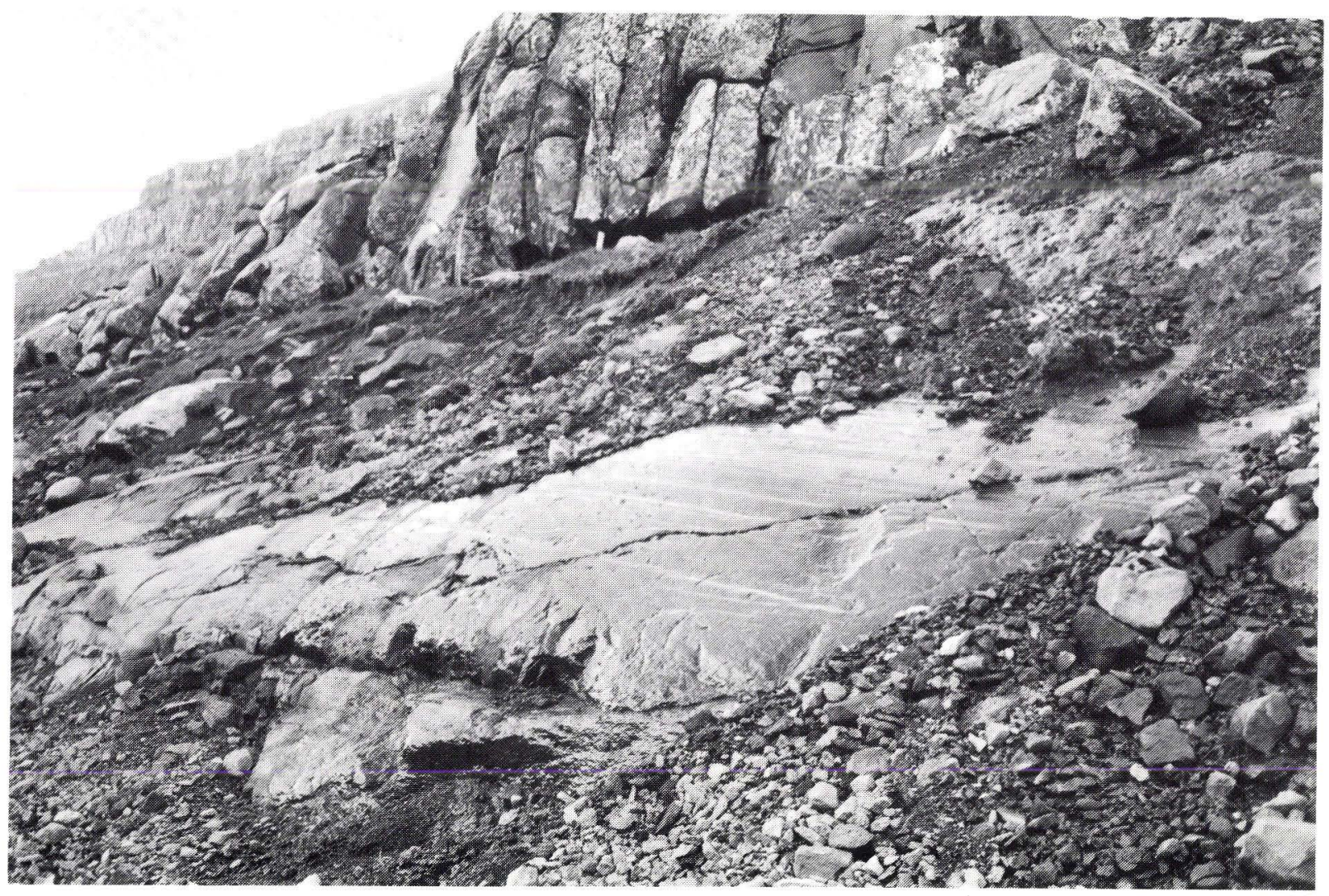

Fig.21. Glacial striae east of site 32 above the road where the ice overflowed the pass to Oyndarfjørour, Eysturoy. 


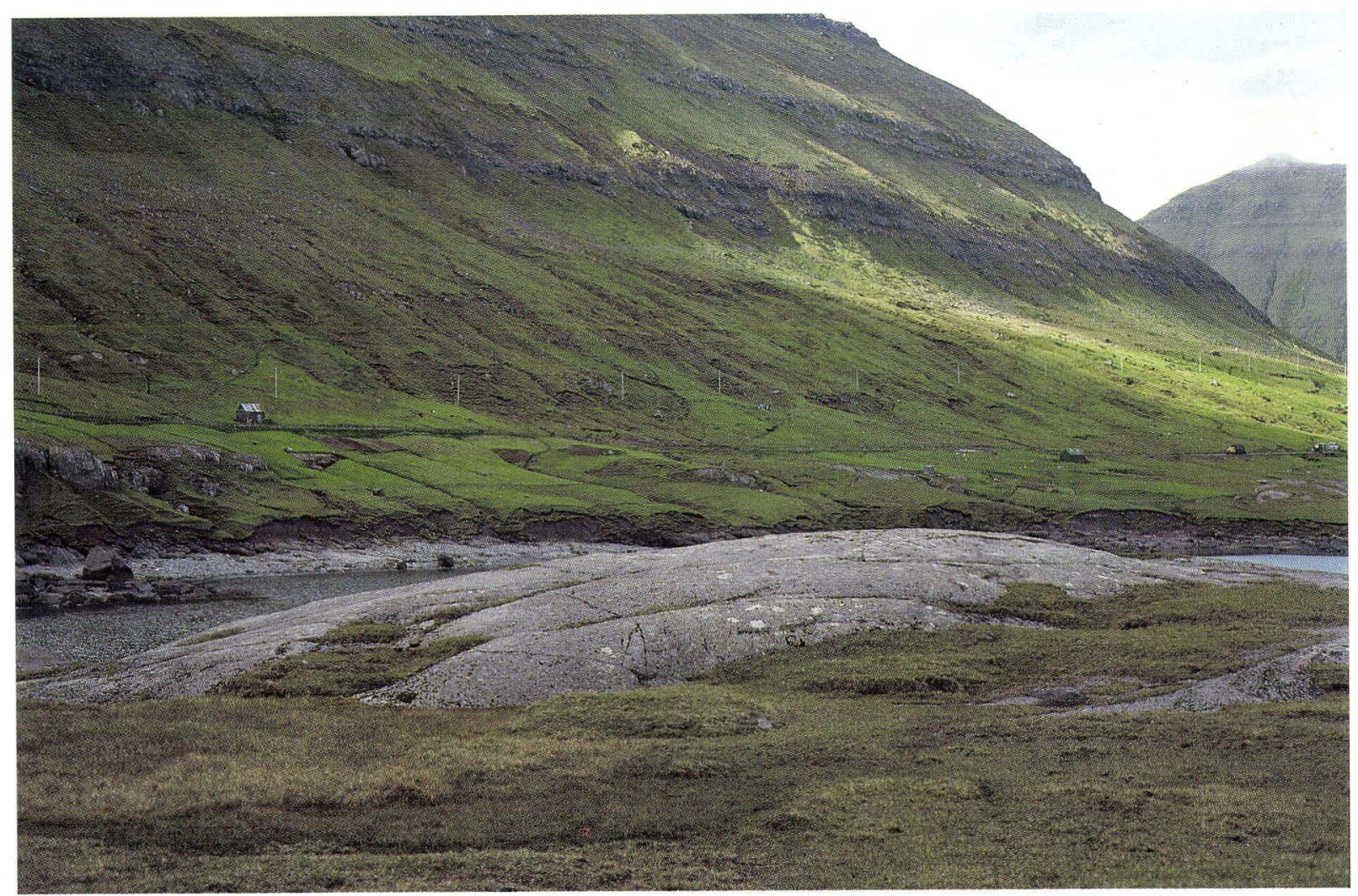

Fig.22. Distinct glaciated rocky area along the head of oyndarfjørour, Eysturoy showing ice movement in NE direction out of the fjord. 
In the north-western part of the valley between skálafjørơur and Funningsfjørơur, and along Funningsfjørour, roches moutonnées and striae follow the valley and fjord direction from NW to NE (sites 56, 53, 28, 22, 23 and 24).

Site 20. Roches moutonnées (NE). Striae (NE-SW).

Site 22. Roches moutonnées (NNW).

Site 23. Roches moutonnées (N).

Site 24. Roches moutonnées (NE).

Site 28. Striae (NNW-SSE).

Site 53. Roches moutonnées (WSW, NW, NNW). Striae (NNW-SSE).

Site 56. Roches moutonnées (NW). Striae (NNW-SSE).

37. Skálafjørơur. Ice movement towards skálafjørour is shown by roches moutonnées (SE) and striae (NW-SE) (sites 54, 55) in the valley between Funningsfjørôur and Skálafjørơur.

From the inner part of Skálafjørơur the ice followed the fjord towards the $\mathrm{SE}$, as indicated by roches moutonnées on the east side of the fjord (side 29) and striae on the west side (site 33). North of Gøtueioi, however, (site 34) roches moutonnées and striae show that the ice here overflowed Gøtueioi (site $34)$ in ESE direction.

In the outermost part of the fjord NNW-SSE trending striae on the west side (site 17), and roches moutonnées further south on the east side, (site 27) indicate that the ice moved SSE out of the fjord.

Site 17. Striae (NNW-SSE). 
Site 27. Roches moutonnées (SSE).

Site 29. Roches moutonnées (SE).

Site 33. Striae (NW-SE).

Site 34. Roches moutonnées (ESE).

Striae (WNW-ESE).

Site 54. Roches moutonnées (SE).

Site 55. Striae (NW-SE).

38. Oyndarfjorôur. From the central part of the valley between Funningsfjørour and skálafjørour, another valley about $5 \mathrm{~km}$ long runs northward to Oyndarfjørour. The slope is steep up from the valley Skálafjørơur - Funningsfjørour (pass height ca. $260 \mathrm{~m}$ ), and continues as a more or less exposed rocky ground area, Heltnin. The rocky area at Heltnin, and the rocks along the head of Oyndarfjorour, are strongly glaciated (figs. 21, 22).

It appears from roches moutonnées and striae (sites $32,31,30,26$ ) that. the ice from the valley between Funningsfjørôur and Skálafjørour moved northward up across Heltnin, and from there NE out of Oyndarfjørour (site 60).

Site 26. Roches moutonnées ( $N$, NNE).

Site 30. Roches moutonnées (NNE).

Site 31. Striae (NNE-SSW).

Site 32. Roches moutonnées (NNE). Striae (NW-SE).

Site 60. Roches moutonnées (NE). Striae (NE-SW).

39. Fuglafjorour. The inner part of Fuglafjørour runs NW-SE, and the outer part opens towards Djúpini and Leirvíksfjørठur.

In the cirques on the west side of the fjord roches moutonnées indicate ice movement to- 
wards the E (site 43) and ENE (site 44). Striae and roches moutonnées on the north side of the fjord show that the ice rounded the coast northwards: ESE (site 40), E (sites 41, 42), NE (site 57) and NNE (site 58).

Site 40. Striae (ESE-WNW).

Site 4l. Striae (E-W).

Site 42. Róches moutonnées (E).

Site 43. Roches moutonnées (E).

Site 44. Roches moutonnées (ENE).

Site 57. Striae (NE-SW).

Site 58. Striae (NNE-SSW).

40. Leirvik. The village of Leirvik is situated at the mouth of two broad cirques, of which the northern one opens towards the east and the southern one towards the north-east. The area is covered with vegetation; there are, however, a few exposures. Between the two cirques, the direction of roches moutonnées is NE (site 48) towards Leirviksfjørour. At Fossagil: (site 59), in the northern part of the village, glaciated surfaces indicate ice movement towards the SE along the coast.

Site 48. Roches moutonnées (NE). Site 59. Roches moutonnées (SE).

41. Gøta. From Skálafjørour the ice overwhelmed Gøtueioi, the pass between skálafjørour and Gøta $(136 \mathrm{~m})$, as shown by roches moutonnées and striae trending ENE-WSW towards Gøtugjógv (site 16). At Gøtugjógv roches moutonnées point NE (site 35 ). Two diverging directions are seen at Nororagøta, one pointing NW through the valley (sites $36,37,38$ ) and the other ESE out of the bay (site 47 ). In a valley on the south side of Gøtuvík roches mou- 
tonnées point $\mathrm{NE}$ and $\mathrm{N}$ in the direction of the bay (sites 45,46 ).

Site 16. Roches moutonnées (ENE). Striae (ENE-WSW).

Site 35. Roches moutonnées (NE).

Site 36. Roches moutonnées (NW).

Site 37. Roches moutonnées (NW).

Site 38. Roches moutonnées (NW).

Site 45. Roches moutonnées (NNE).

Site 46. Roches moutonnées (N).

Site 47. Roches moutonnées (ESE).

42. Lambi. A valley trending almost due E-W runs from Skálafjørour to Lambi. Here the ice overflowed a pass more than $50 \mathrm{~m}$ high, Lambareioi, and continued eastward towards Lambavik (sites 12, 13).

Site 12. Roches moutonnées (E).

Site 13. Roches moutonnées (E).

43. Rituvík - Very well preserved striae trending NW-SE are observed at Runavík in Skálafjørour (site 10). At Rituvik on the east coast both striae and roches moutonnées indicate ice movement in a SE direction (sites 6-9).

Site 6. Roches moutonnées (SSE).

Site 7. Striae (NNW-SSE).

Site 8. Striae (NW-SE).

Site 9. Striae (NW-SE).

Site 10. Striae (NW-SE). 
NORDOYAR (THE NORTHERNMOST GROUP OF ISLANDS). The northernmost group of islands, Noroyar, comprises the islands Kalsoy, Kunoy, Borboy, Viðoy, Svínoy and Fugloy; they have a total area of about $240 \mathrm{~km}^{2}$. Kalsoy is separated from Eysturoy by Djúpini. Apart from the two easternmost and smallest islands, svinoy and Fugloy, the islands are elongate and trend NW-SE. They are separated by narrow sounds: Kalsoyarfjørour (Kalsoy - Kunoy), Haraldssund (Kunoy - Borð̌oy) and Hvannasund (Borð̌oy - Við̌oy). The mountains generally reach heights of 600-800 m.

Noroyar are mostly built up of the middle basalt series, which is overlain by the upper basalt series except on Fugloy, Svinoy and on the southernmost part of Boroy; here only. the upper basalt series is present. The dip is generally south-easterly $\left(10-2^{\circ}\right)$, but on the northernmost islands slightly north-northeast. The dominant directions of dykes and lamellar zones trend NNE-SSW and NE-SW.

Above the c-horizon (the boundary between the middle and the upper basalt series) the landscape has a trap or terraced profile, like the landscape of sururoy. On the Noróoyar, however, the profile is steeper and the steps (traps) are smaller. Below the c-horizon, on the other hand, the landscape has gentle slopes towards the coast. The terrain is for the most part covered with scree from the overlying beds, or vegetation. Exposures are few and the rocks often weathered. Cirques are numerous, mainly on the east sides of the islands.

44. Kalsoy. On the west side of the island striae trending $\mathrm{N}-\mathrm{S}$ were observed between Lambagjógv and Hvannagjógv (site 1 ).

In the cirques Hattardalur (site 6), Villin- 
gadalur (site 2), Ritudalur (site 3) and Mikladalur (site 4 ) on the east side of the island no distinct striae and roches moutonnées were observed, but some less distinct stoss and lee sides have been indicated by dash-lines on the map.

Immediately north of the village of Húsar some rather flat roches moutonnées pointing to the SSE (site 7) were seen, and below the road at Myllá south of Húsar several weakly developed roches moutonnées point almost due SE (site 8).

Site 1. Striae (N-S).

Site 2. (Dashed) roches moutonnées (NNW).

Site 3. (Dashed) roches moutonnées (NNW).

Site 4. (Dashed) roches moutonnées (NNW).

Site 6. (Dashed) roches moutonnées (NNW).

Site 7. Roches moutonnées (SSE).

Site 8. (Dashed) roches moutonnées (SE).

45. Borboy. On the west side of the island Klaksvik and Borooyarvik are connected by an isthmus. The southern part of the island branches into three small peninsulas, separated by Borooyarvík and Arnafjørdur.

North of Stórá, at the village strond, roches moutonnées point WNW (site 20), NNW (site 12) and NW (site 7). Further to the north, at Krossdalsáir, striae trend $\mathrm{N}-\mathrm{S}$ (site 2 ).

South of Stórá roches moutonnées point WSW (sites 15 and 19) and $\mathrm{SW}$ (site 16). In the valley above the water reservoir in strandardalur the rocky ground is heavily glaciated, and shows ice movement down the valley (site 18). 
South-east of Anir roches moutonnées show ice direction towards the Sw (site 17).

At Klaksvik the ice moved northwards (sites 10, 11, 13, and 14), and at Borboyarvik southwards (sites 1, 9, and 21). Our observations at Borooyarvik were made on the west side. Observations on the east side have been given by Grossmann \& Lomas (1895).

Arnafjørour is terminated to the NW in a cirque. On both sides of the valley the C-horizon is well exposed. Roches moutonnées indicate ice movement towards the SE (site 3). Striae trend NW-SE (site 3) and NNW-SSE (site 4). Further south along the eastern shore roches moutonnées point SSE (site 8 ).

At Hvannasund well-preserved roches moutonnées south of Argisdalur show ice movement towards the NNW (site 5), the same directions as further north (site 6).

Site 1. Striae (NNW-SSE).
Site 2. Striae (N-S).
Site 3. Roches moutonnées (SE).
Striae (NW-SE).
Site 4. Striae (NNW-SSE).
Site 5. Roches moutonnées (NNW).
Site 6. Roches moutonnées (NNW).
Site 7. Roches moutonnées (NW).
Site 8. Roches moutonnées (SSE).
Site 9. Roches moutonnées (SSE).
Site 10. Roches moutonnées (N).
Site 11. Roches moutonnées (N).
Site 12. Roches moutonnées (NNW).
Site 13. Roches moutonnées (NNW).
Site 14. Roches moutonnées (NNW).


Site 15. Roches moutonnées (WSW).

Site 16. Roches moutonnées (SW).

Site 17. Roches moutonnées (SW).

Site 18. Roches moutonnées (WSW).

Site 19. Roches moutonnées (WSW).

Site 20. Roches moutonnées (WSW).

Site 21. Roches moutonnées (ESE).

46. Viooy. At the old landing-place on the west side of the island (site 1) striae trending WNW-ESE are seen in the bedrock beneath a moraine (Noe-Nygaard 1939). Immediately south-west of Malinsfjall, above the road to Hvannasund, striae trending NNW-SSE and stoss and lee sides indicate ice movement towards the north (site 2) (fig. 23). Just south of the village of Hvannasund well-glaciated exposures on the surface of the c-horizon are seen. Striae trending $\mathrm{N}-\mathrm{S}$ and roches moutonnées indicate ice movement towards the south (site 3 ).

Site 1. Striae (WNW-ESE).

Site 2. Striae (NNW-SSE).

Site 3. Roches moutonnées (S).

Striae $(\mathrm{N}-\mathrm{S})$.

47. Svinoy is separated from Viooy by svínoyarfjørour and from Fugloy by Eugloyarfjørour. The island is divided into a northern and a southern part by the isthmus svin oyareiði.

Immediately south of the village of svinoy (site 1), north of the foreland Dragin (site 2) and east of Stórá at $80 \mathrm{~m}$ a.s.1. (site 3), striae trending $E-W$ were observed.

Site 1. Striae $(E-W)$.
Site 2. Striae $(E-W)$.
Site 3. Striae $(E-W)$. 


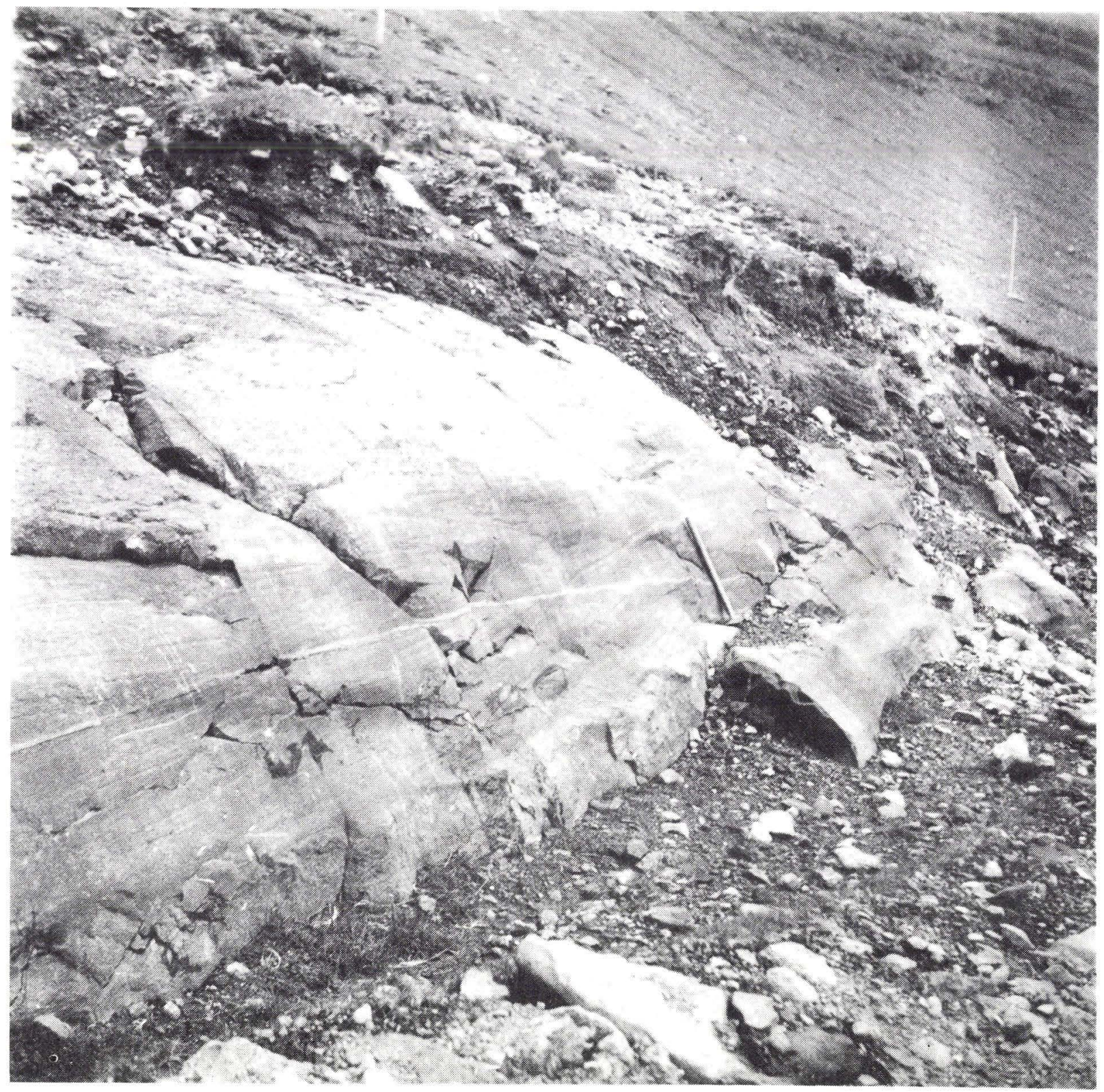

Fig.23. Glaciated rock south-east of the village of Viðareiði, Viðoy, indicating ice movements to the north. 
114 
FØROYAR

The Faeroe Islands

Glacial striae, roches moutonnées and

ice movement in the Faeroe Islands

(1)
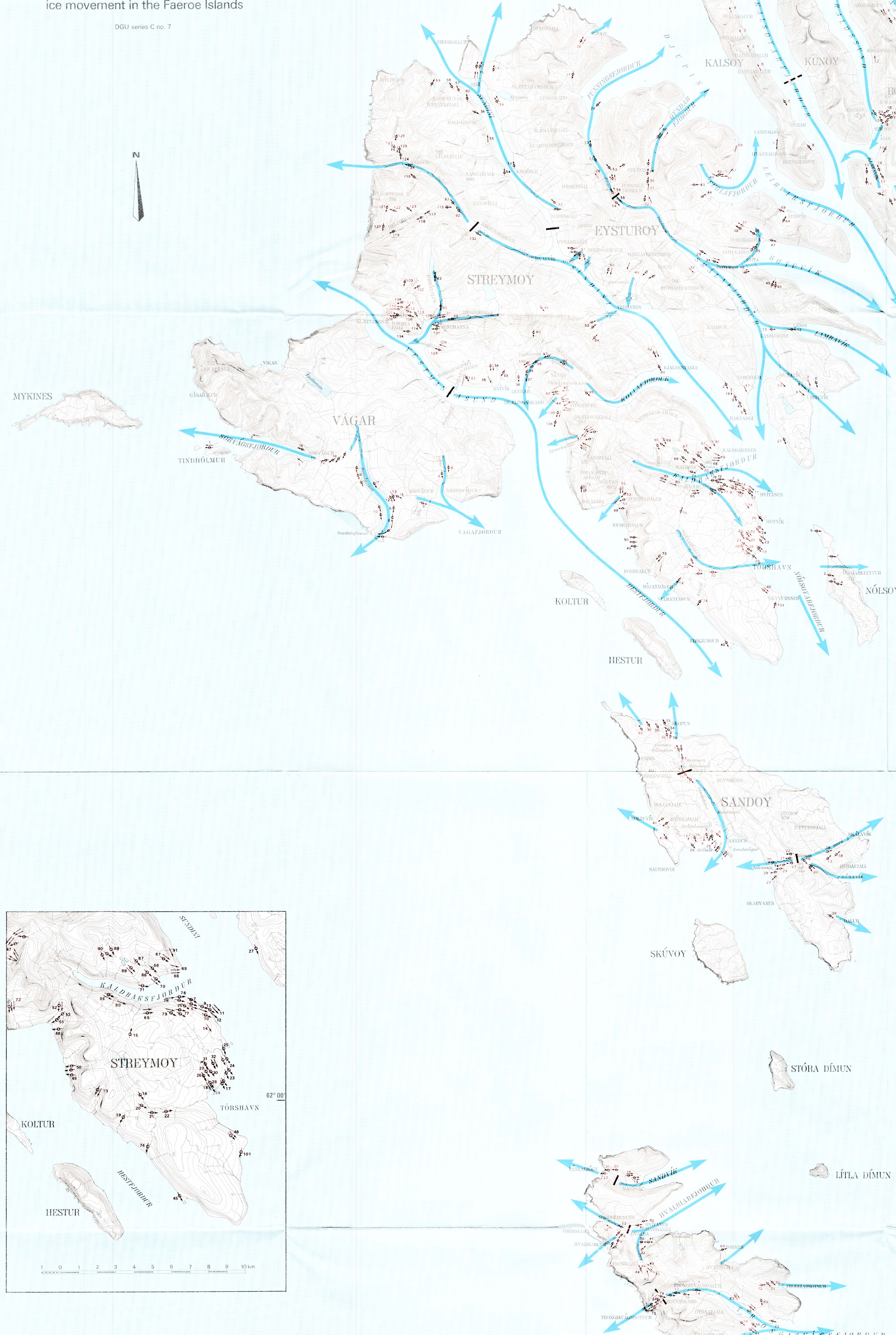

LEGENDE

- Direction of glacial striae

$\Rightarrow$ Main direction of ice movement

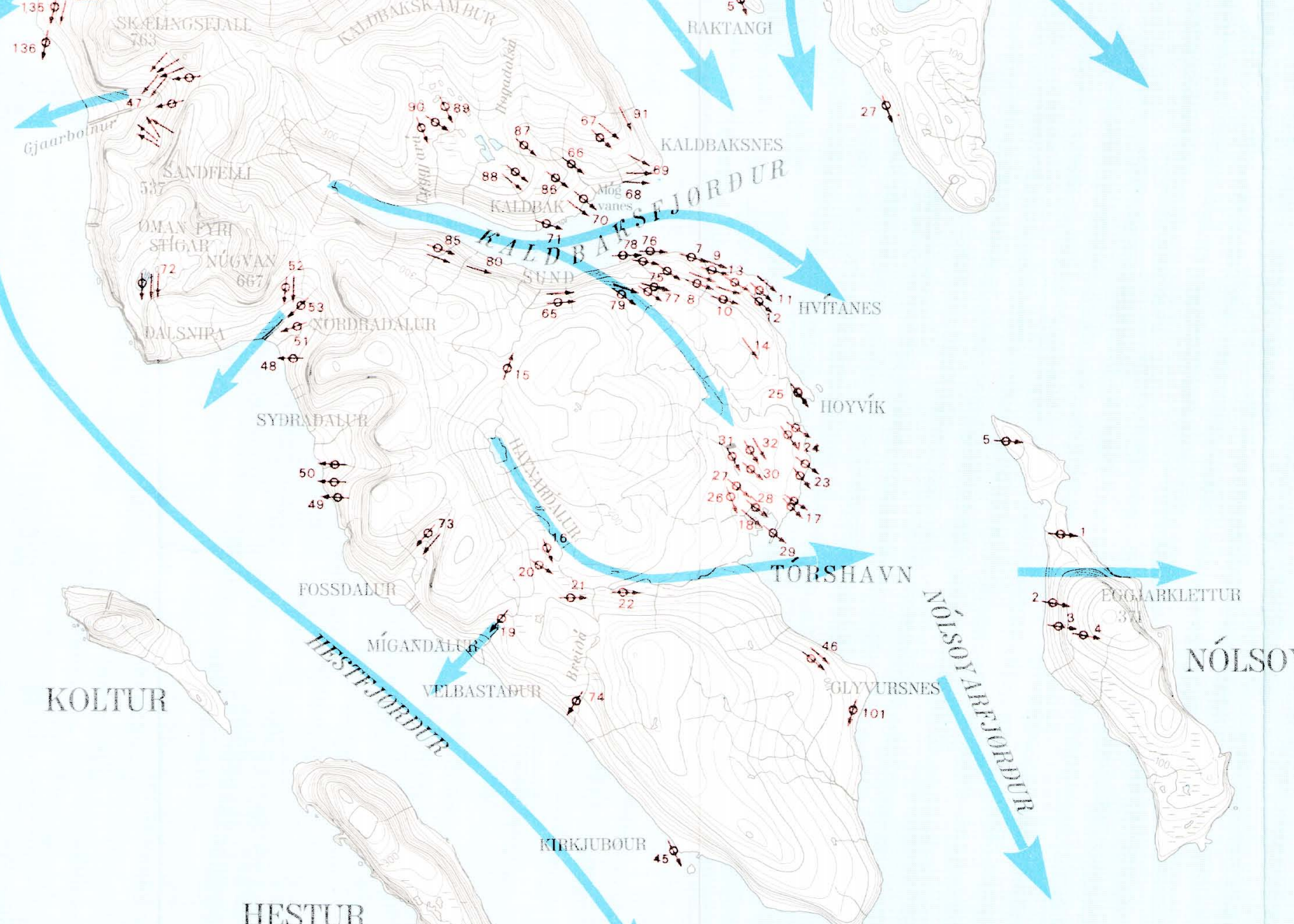

HESTUR YI AY

thes

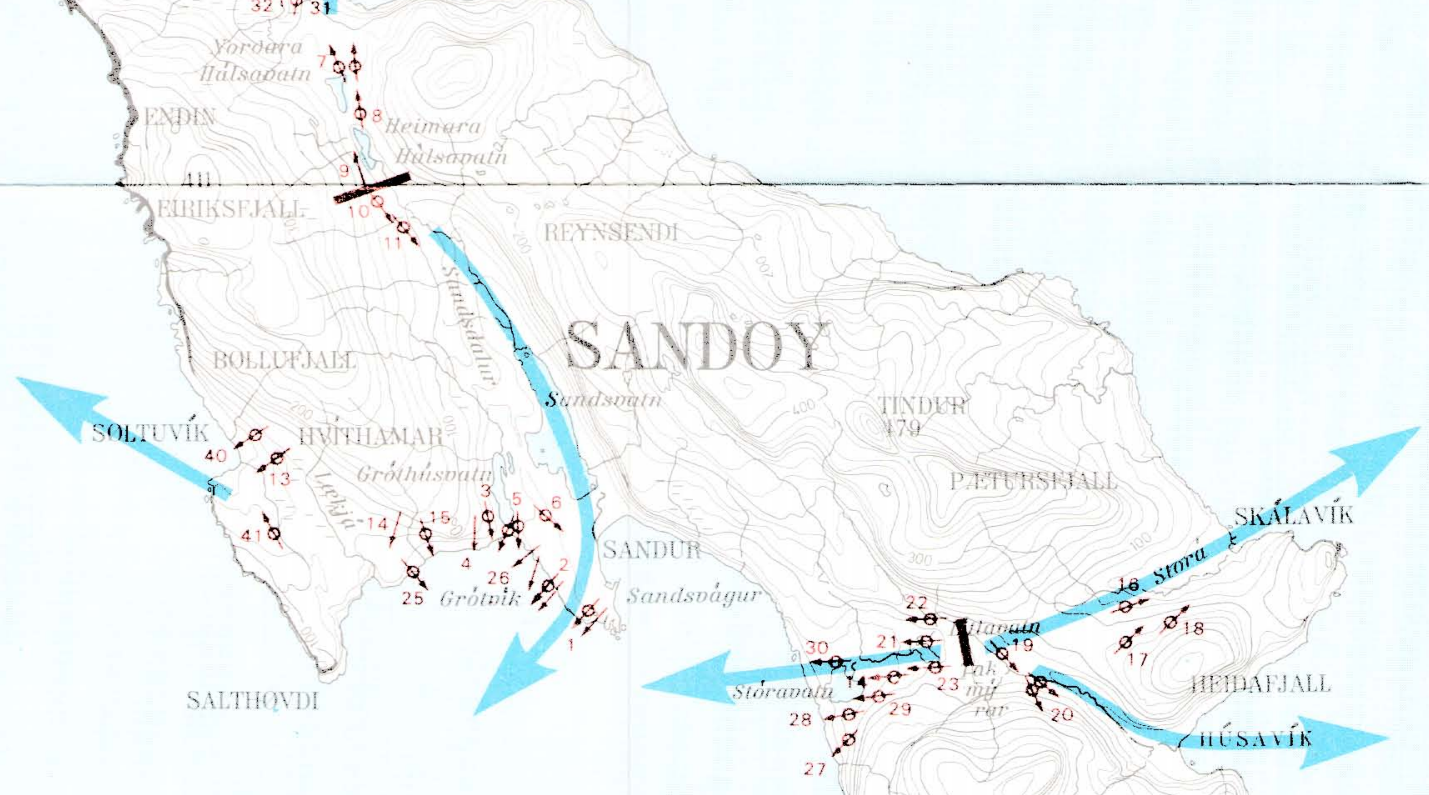

SUDUROY :

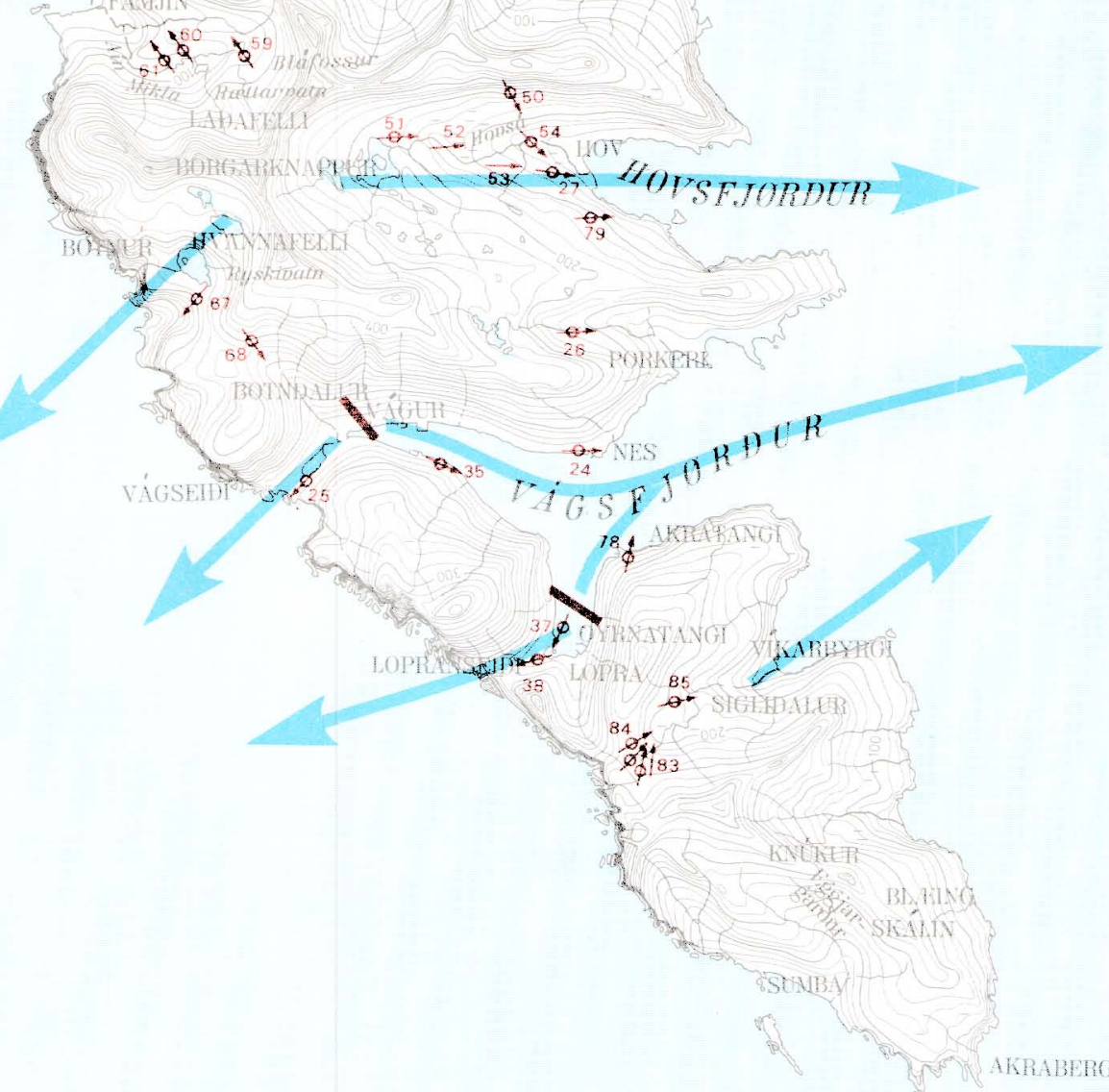

I- Iceshed 
The paper deals with glacial striae, roches moutonnées and ice movement in the Faeroe Island. It is a statement of our knowledge on the subject to date accompanied by a map and an appendix with decription of localities. 